Portland State University

PDXScholar

5-7-1996

\title{
Oregon Territorial Governor John Pollard Gaines: A Whig Appointee in a Democratic Territory
}

Katherine Louise Huit

Portland State University

Follow this and additional works at: https://pdxscholar.library.pdx.edu/open_access_etds

Part of the History Commons

Let us know how access to this document benefits you.

\section{Recommended Citation}

Huit, Katherine Louise, "Oregon Territorial Governor John Pollard Gaines: A Whig Appointee in a Democratic Territory" (1996). Dissertations and Theses. Paper 5293.

https://doi.org/10.15760/etd.7166

This Thesis is brought to you for free and open access. It has been accepted for inclusion in Dissertations and Theses by an authorized administrator of PDXScholar. Please contact us if we can make this document more accessible: pdxscholar@pdx.edu. 


\section{THESIS APPROVAL}

The abstract and thesis of Katherine Louise Huit for the Master of Arts in History were presented May 7, 1996, and accepted by the thesis committee and the department.

COMMITTEE APPROVALS:

DEPARTMENT APPROVAL:

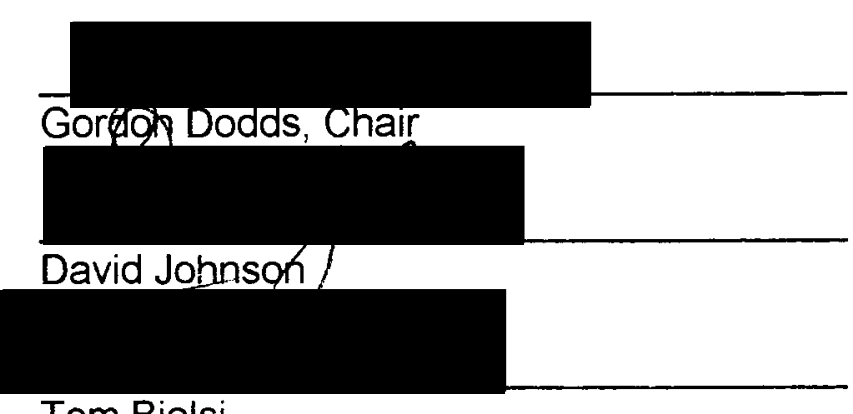

Tom Biolsi

Representative of the Office of Graduate Studies

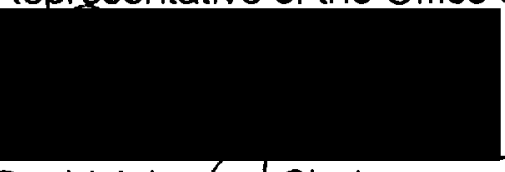

David Johnson, Chair

Departmentof History

ACCEPTED FOR PORTLAND STATE UNIVERSITY BY THE LIBRARY

by on

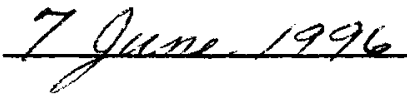


An abstract of the thesis of Katherine Louise Huit for the Master of Arts in History presented May 7, 1996.

Title: Oregon Territorial Governor John Pollard Gaines: A Whig Appointee In A Democratic Territory.

In 1846 negotiations between Great Britain and the United States resulted in the end of the Joint Occupancy Agreement and the Pacific Northwest became the property of the United States. Nineteenth Century Oregon represented a new beginning for many citizens of the United States and around the world. The settlers arriving in the Oregon Country consisted of a hardy, self reliant, breed; yet they sought the protection of the United States government from Native Americans living in the region and from Great Britain's Hudson's Bay Company. When Oregon became a territory, in 1848, the pioneers struggled to preserve their independence. They resented federally appointed officials sent to govern them by the United States Government. Governor John Pollard Gaines, the subject of this study, came to Oregon as a federally appointed official.

Previous studies of the Oregon Territorial Government have examined in detail the marked conflict between the political parties of the Oregon Territory. Before 1850 Oregon did not have two distinct political parties. Governor Gaines, a Whig, acted as a catalyst for the birth of a strong Democratic party in Oregon. On the federal level the Whig and Democratic parties had been at odds since the time of Andrew Jackson. The Whigs were 
proponents of economic progress contained within a social and political framework. Whigs promoted individual and national independence; Democrats promoted the dependence cf one class upon another. Whigs believed the pursuit of individual liberty and national prosperity depended upon an active government representative of its citizens' interests.

This study examines "home rule" Democrats, their treatment of Governor Gaines, and the ramifications of the Governor's reactions at a local and federal level. As a federally appointed official sent to govern the distant Oregon Territory, Gaines endured abuse from "home rule" citizens. Conclusions drawn from this study demonstrate that Gaines's affiliation with the Whig party is secondary to his being an "outsider." His treatment as governor would not have been much different if he had been a Democrat sent to the Territory by the federal government. 
OREGON TERRITORIAL GOVERNOR JOHN POLLARD GAINES:

A WHIG APPOINTEE IN A DEMOCRATIC TERRITORY

by

KATHERINE LOUISE HUIT

A thesis submitted in partial fulfillment of the requirements for the degree of

\author{
MASTER OF ARTS \\ in \\ HISTORY
}

Portland State University

1996 
OREGON TERRITORIAL GOVERNOR JOHN POLLARD GAINES:

A WHIG APPOINTEE IN A DEMOCRATIC TERRITORY

\section{TABLE OF CONTENTS}

Chapter One: The Appointment.

Chapter Two: Slavery, Economic Depression, and Manifest Destiny ...............22

Chapter Three: A New Territory, Its Officials, and Partisan Politics ..................33

Chapter Four: Whigs, Democrats, The Mexican War, and The Presidential Election Of 1848

Chapter Five: Around The Horn To Oregon ...............................................61

Chapter Six: A Whig Appointee In A Democratic Territory ...............................80

Chapter Seven: Inextricable Aggravation and Gallant Perseverance ............. 100

Chapter Eight: Forgotten Deeds ............................................................ 135

Chapter Nine: The Post-Governor Years …................................................. 178

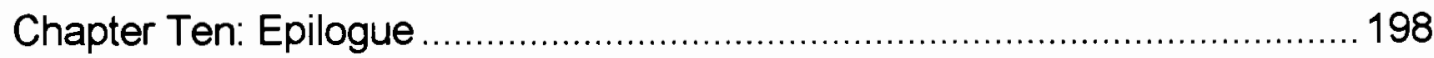

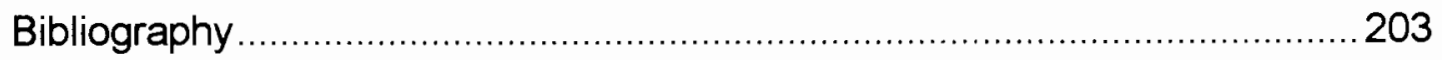




\section{THE APPOINTMENT}

"My Father having rec'd an appointment from the President as Gov. Of the Territory in the month of Oct-49 . . . determined to sell his property in the county of Boone, State of Kentucky . . . and make permanent residence in that countryThe policy of his sudden, unexpected and hazardous change was doubted by some of his friends- Many more loathed to part with him on account of the valuable services he had rendered the state politically ..."1

Late in the evening of December 1,1849, two men sat with the President in Washington City, engrossed in a discussion about the Oregon Territory. ${ }^{2}$ Zachary Taylor, major general in the recent war with Mexico, had attained the presidency of the United States as a Whig. Major John Pollard Gaines, a distant relation of the President's, ${ }^{3}$ had also fought in the Mexican War where he became a prisoner of war and received several commendations for his service.

Taylor originally asked Abraham Lincoln to be Oregon's territorial governor; however, Lincoln declined, so the president chose Gaines. As Taylor and Oregon Territorial Delegate Samuel Thurston explained the duties of territorial governor, Gaines reflected back over his life.

Gaines and his family had spent the last few months preparing for the trip around the Horn to the Oregon Territory. Upon learning about his appointment in

\footnotetext{
${ }^{1}$ Archibald K. Gaines, Archibald K. Gaines Joumal. Coe Manuscript Collection, (Yale University Library, New Haven, Connecticut, unnumbered pages). This manuscript appears to be part joumal, part remembrance. The later part of the diary is written at John Pollard Gaines's passing, and recounts his years in Oregon as well as the voyage around Cape Hom. A hand written copy of the remembrance portion of the joumal is located in the Gaines Family Papers, MSS 683, Oregon Historical Society Library.

2 Samuel Royal Thurston, "Diary of Samuel Royal Thurston, November 21, 1849 - August 28, 1850." Oregon Historical Quarterly, XV (number 3, September 1914), p. 156.

${ }^{3}$ Letter to Katherine Huit from Pendleton Gaines, May 28, 1994. This letter refers to Gaines family history and genealogy. It is in Katherine Huit's possession.
} 
October $1849,{ }^{4}$ Gaines sold his Kentucky plantation to his brother, Archibald K.

\author{
Gaines. ${ }^{5}$ The Gaines family had lived in the same area of Kentucky ever since
}

\begin{abstract}
${ }^{4}$ The appointment date and from whom Gaines received his appointment to the position of Teritorial Govemor of Oregon differs from source to source. The Biographical Encyclopaedia of Kentucky of the Dead and Living Men of the Nineteenth Century (Cincinnati: J. M. Armstrong \& Company, 1878), p. 518, gives Gaines's appointment date as September of 1850 by President Millard Fillmore. This differs from Lang, H. O., ed., History of the Willamette Valley (Portland, Oregon, Geo. H. Himes, Book and Job Printer, 1885), which states, "In April, 1850, Govemor Lane received notification that he had been removed by the Whig President, Taylor, and Major John $P$. Gaines appointed in his place on the second of the previous October." Archibald Kinkead Gaines, John Pollard Gaines's son, refers to his father's appointment date as October 1849. See Archibald $K$. Gaines Joumal. This seems to verify the account given by Lang. H. R. Kincaid, in the Biennial Report of the Secretary of State -- Oregon 1897-98 (Salem, Oregon, W. H. Leeds, State Printer, 1899), pp. 166-167, states that President Taylor appointed Gaines to the govemorship in 1849, and that Gaines "started for Oregon in a sailing ship, leaving New York January 3, 1850." This account seems to coincide with Lang. Both books are Oregon publications, and were written approximately the same time. Most likely Kincaid drew his biographical information from Lang. Lewis Collins's History of Kentucky (Covington: Collins \& Co., 1882) states that on "September 9 , 1850, President Fillmore appointed [Gaines] Govemor of Oregon Temitory, which office he held until March 16, 1853." He did hold office until 1853, but the date given here may be when he began his duties as govemor in Oregon, not the actual appointment date. The official paper signed by Taylor appointing Gaines to the office of Temitorial Govemor of Oregon, demonstrates that Zachary Taylor did, in fact, appoint Gaines. A copy of the appointment paper is in the John Pollard Gaines Papers, (hereinafter referred to as the Gaines Papers), seven archival boxes of original documents, housed at the New York State Library, Albany, New York. (The Gaines Papers are available on four reels of microfilm and the appointment paper is at the end of reel four. The microfilmed version of the Gaines Papers is available at the Oregon Historical Society, Portland, Oregon, MSS 187.) Unfortunately, in 1911 a fire destroyed the New York State capitol which housed the Gaines Papers. Consequently, these documents are difficult to read. I have, however, been able to glean enough information from them to substantiate and/or contest events in Gaines's life, including his appointment as temitorial govemor of Oregon. The appointment papers clearly show Taylor's signature and make reference to "the second," as a date; however, the month and year are not legible. By consulting the sources mentioned above, I have been able to narrow the actual appointment date to October 2, 1849. Other sources consulted, including Hubert Howe Bancroft, The Works of Hubert Howe Bancroft, Volume XXX, History of Oregon, Volume II, 18481888 (San Francisco: The History Company Publishers, 1888), Joseph Gaston's The Centennial History of Oregon (Chicago: The S. J. Clarke Publishing Company, 1912), and George S. Tumbull's Govemors of Oregon, (Portland: Binfords and Mort Publishers, 1959), give no appointment dates, nor do they mention which president appointed Gaines -- only that the administration succeeding Polk appointed him.

5 Archibald K. Gaines Joumal. The Fort Worth Public Library has a typescript titled "Around Cape Hom: A Voyage from New York to Oregon Temitory by Sailing in 1850". It came into the library's possession through Lone Star Chapter DAR Genealogical Records Chairman, Martha Woods Gaines (Mrs. Collins Gaines). Collins Gaines of Texarkana, Texas, a great-nephew of John Pollard Gaines, prepared this typescript version. The University of Texas Archives, Austin, Texas, and the Arkansas State Archives in Little Rock, Arkansas, through the efforts of Mrs. Arthur Jennings, have additional copies of the typescript version of the dianies. See also John Pollard Gaines, Diaries of Major John Pollard Gaines: "March of the First Regiment of Kentucky Volunteer
\end{abstract}


Abner Legrand Gaines brought his wife, Elizabeth, and their small children ${ }^{6}$

"down the buffalo trail," later known as the Lexington Pike. ${ }^{7}$ Born September 22, 1795, young John Pollard Gaines traveled with his father, mother, and older

brother from Augusta County, Virginia, to Kentucky late in the eighteenth century. Upon reaching their destination, they camped in their wagon while Abner built a three-room cabin. Living in two rooms of the cabin, they used the third for a store. The family realized a profit while operating the store and, as settlers arrived and claimed land for their own, the area became known as Gaines's Crossroads. In 1840 the location became Walton, Kentucky, by an act of the Kentucky

Cavalry, From Memphis, Tennessee to Mexico, During the War with Mexico in 1846," also located at the Fort Worth, Texas, Public Library and purported to be a copy of the original prepared by Collins Gaines. Another copy located at Little Rock, Arkansas, contains a map of Mexican War campaigns. The Filson Club in Kentucky received a typescript copy titled "The Diary of Major John P. Gaines Duning His Trip To the Mexican Border During the War With Mexico" from Mr. Ashlin Logan in 1980. I have been unable to obtain a copy of the Logan typescript, but suspect it is the same document Collins Gaines gave to the Library in Fort Worth. Through a comparison of documents I have verified that portions of the typescript diary about the family voyage around Cape Hom are almost verbatim passages of the Archibald $K$. Gaines Joumal which covers the voyage and the family's time in Oregon. There is a diary about the voyage around Cape Hom in the Gaines Papers; however, it went through the state capitol fire at Albany, New York, and is almost entirely unreadable. There is a short passage that I can verify is very similar to the Collins Gaines version. It is possible Collins Gaines embellished the Archibald K. Gaines's Joumal , and the diary in the Gaines Papers, with family remembrances or that he may have had access to a copy of the John Gaines diary. Because of my concem about the authenticity of the Collins Gaines version of John Gaines's diary, for the most part, when refeming to the voyage around Cape Hom, I have cited the Archibald K. Gaines Journal. Until I can prove otherwise, I have assumed the diary about the march to Mexico is an authentic copy of the original, and hereinafter I will refer to this diary as The Gaines Diary: Mexico.

${ }^{6}$ J. Lewis Peyton, History of Augusta County, Virginia (Staunton, Virginia: Samuel M. Yost \& Son, 1882), p. 317. Abner Legrand Gaines mamied Elizabeth Mathews in 1789. Between 1793 and 1818 they issued twelve children: James Mathews, John Pollard, William H., Mary W., Richard M., Benjamin F., Augustus W., Archibald K., Abner, Elizabeth, Mildred Pollard, and Hamet $B$. All of these children lived to be adults, and at least ten of them issued offspring.

${ }_{7}^{7}$ Hendricks, R. J., "Bits for Breakfast," Oregon Statesman (February 12, 1930), p. 4. Hendricks used a manuscript, titled "Walton's Great Statesman," written by C. Spencer Chambers of Walton, Kentucky, as a source for his piece on Gaines's early life. Hendricks acquired the piece from Sarah Coates who in tum acquired it from B. J. Mathews, most likely a relative in Gaines's 
Legislature. $^{8}$

As most children during the early nineteenth century, John Gaines

received his early education from his mother. When old enough, he clerked in

his father's store, where he learned about "human nature" from the customers,

knowledge which helped him deal with people in his future career. Whenever his

father went on a purchasing trip to secure merchandise for the store he acquired

"books and papers" to assist in John's "mental development." Young John had

decided to become a lawyer and clerking did not keep him too busy to devote a

portion of his time to study. ${ }^{9}$

matemal line. Unfortunately, I have been unable to locate the original work, therefore, I rely on Hendricks' authonity regarding its authenticity.

${ }^{8}$ Robert M. Rennick, Kentucky Place Names (Lexington, Kentucky: The University of Kentucky Press, 1987), p. 281. Rennick says of Walton, Kentucky, "The site is said to have been first settled in 1786 by a Virginia-bom Revolutionary War veteran, Col. Abner Gaines, who, with the financial help of a ship's captain named Walton, est[ablished] an important tavem and stage stop on the roa]d between Covington and Lexington (now US 25). The local P[ost] O[ffice] was est[ablished] as Gaines on July 4, 1815, with James M. Gaines [Abner's eldest son], p[ost] m[aster] . . . the community was called Gaines'[s] Cross Roads until, by an act of the Kentucky legislature in 1840, it was renamed, allegedly for the captain. A limited search produced no record of this person. The $\mathrm{p}$ [ost] o[ffice] also assumed the Walton name in 1840 and the town was inc[orporated] as such in 1854." The "150th Anniversary of the City of Walton, 1840-1990," (Walton, Kentucky, January 21, 1990 , p. 17-18), also gives an account of the settlement and founding of Walton by Abner Gaines. This publication states Abner Gaines amived in the area in 1785 and "built a log cabin with the help of his family and slaves." As the family grew, Abner enlarged the cabin, and eventually, with the help of "Mr. Walton, a well-to-do steamboat captain," he built a brick house in 1791. These two accounts conflict with the genealogy records, which indicate the first child of Abner and Elizabeth, James Mathews Gaines, was not bom until 1793. Further, Abner and Elizabeth did not marry until 1789. In his Oregon Statesman article, Hendricks maintains that at the time of Gaines's amival, the state of Kentucky had just tumed five, and further that John Pollard Gaines was but a "two year old baby nestling in his mother's arms." Hendricks also states that Abner built his three room house "with the assistance of John Walton, a pioneer living about a mile out on what is now High Street in Campbell county, as Kenton had not become a county at this time." This account seems more reasonable with regard to dates, as Kentucky became a state in June 1792 and John Pollard Gaines was bom in September, 1795. It is also possible that Abner Gaines traveled to Kentucky ahead of his wife, perhaps even before his mamiage, located the land he desired, and retumed later with his wife and family. The account of an individual named Walton assisting Gaines seems to coincide with other sources.

${ }^{9}$ Hendricks. 
In the year 1812, the young United States faced another war. John, by now an avid reader of the newspaper, saw an advertisement for volunteers and followed the course of many other young American men of the day. His father's hopes were "shattered," and his "mother's heart filled with sorrow," when young John "decided he would do his bit" in the war effort. ${ }^{10}$ At seventeen years of age, John Pollard Gaines became Boone County's only volunteer in the War of 1812 . After a show of "extraordinary bravery at the Battle of the Thames,"11 he returned to Walton and his law studies, restoring the hopes of his parents. After passing the Kentucky bar examination in 1816, Gaines opened a law practice in his home town. $^{12}$

On June 22,1819 , at twenty-four-years-old, John Gaines, a "dashing veteran of the War of 1812," married Elizabeth Kinkead, a "Southern Belle with Presbyterian upbringing." ${ }^{13}$ The couple married at Versailles, Kentucky, making their home in Walton where they began a family. Elizabeth bore John eleven children between June 1820 and March $18411^{14}$

\footnotetext{
10 lbid.

11 lbid.

12 Ibid.

${ }^{13}$ Ibid. Elizabeth was the daughter of Nicholas and Priscilla McBride Kinkead.

14 Archibald K. Gaines Joumal. This journal's author, Archibald Kinkead Gaines, was the oldest surviving son of John Pollard Gaines. The children, in birth order, include Anna Maria, (June 1, 1820 - October 29, 1821); Abner P., (December 27, 1821- August 7, 1835); Archibald Kinkead, (Novermber 30, 1823 - 1895); Richand M., (December 17, 1825 - January 28, 1866); Ann Maria, (June 2, 1827 - Unknown); Florelle, also spelled Florell and Florella, (July 14, 1829 - March 22, 1850); Mary Elizabeth, (July 25, 1830 - June 23, 1834); Harriette (also spelled Harriet and Harrietta) Byme, (February 6, 1833 - March 19, 1850); Abner Pendleton, (March 23, 1835 Unknown); Mary Elizabeth, (May 13, 1839 - Unknown); Matilda F., affectionately called Tillie by her father, (March 14, 1841 - March 23, 1857).
} 
By the early 1820 s Gaines's law practice flourished as a result of his focusing on land title disputes emanating from overlapping land grants. His popularity grew and soon he found himself elected to the Kentucky Legislature, where he served as a representative from Boone County during the sessions of $1825,1826,1827,1830$, and $1832 .^{15}$

While serving as a legislator, and continuing his law practice in Walton, Gaines also worked on his land as a farmer. In Kentucky, he became known as an individual "with talents if not of the first order, at least respectable, and every way sufficient to qualify him to discharge the duties which may devolve upon him . . ."16 Gaines's popularity gained him state-wide recognition, and in April of 1842, at a public meeting in Walton, the citizens of that community nominated him as a candidate to represent them in their state senate. ${ }^{17}$ On May 4, 1842, the citizens of Florence also resolved to choose Gaines as their candidate for the senate. ${ }^{18}$ At the Whig convention, held on May 21, 1842, at Napoleon, "for the purpose of nominating a candidate of for the State Senate," Gaines emerged the candidate. $^{19}$

Despite his defeat in this election, his continued popularity gained him a

\footnotetext{
${ }^{15}$ Hendricks. Collins, p. 55; Letter to Katherine Huit from Leslie Cummins of the Kentucky Legislative Research Commission, August 11, 1995. The letter is in Kathenine Huit's possession. The complete session dates of Gaines service as a representative in the Kentucky Legislature are November 7, 1825 - December 21, 1825; December 4, 1826 - January 25, 1827; December 3, 1827 - January 13, 1828; December 6, 1830 - January 15, 1831; and December 3, 1832 February 2, 1833.

${ }_{16}^{16}$ Licking Valley Register, June 28, 1845, p. 2.

17 Ibid., April 16, 1842, p. 3.

18 Ibid., May 7, 1842, p. 3.

19 Ibid., June 4, 1842., p. 3.
} 
nomination as a Whig representative to Congress from Kentucky in 1845. It was the custom of the convention delegates to appoint a committee to inform the nominee of his candidacy. Major Charles S. Clarkson gave a short presentation about Gaines to the convention while they waited for him to arrive. Clarkson had known Gaines "intimately for more than thirty years." ${ }^{\text {He }}$ He told the convention about his first meeting with a young John Gaines:

"... [A]t the age of 17, Mr. Gaines petitioned his mother, to permit him to enter the army as a volunteer. His mother, after some hesitation, consented, that he might do so, if he [then Captain Clarkson, and a friend of hers] would take the youthful soldier under his especial care; and at this early period of life, John P. Gaines, fired with that love of country which has always characterized him, shouldered his gun, and marched to the Northern Frontier, (at the time invaded by the enemies of our country) to defend our firesides and homes." ${ }^{21}$

When Gaines appeared, the delegates welcomed him with a warm applause.

Speaking to the convention, Gaines stated that the delegates had "overrated" his capacity but "he intended to put himself in the way of examination by the people, and he besought the convention, to tell their friends . . that they had nominated a plain man, least expectations should be raised which would be disappointed."22

The Licking Valley Register touted Gaines as

". . . the man in whom the people can place implicit confidence. He will be found true as steel. There will be no dodging $u r$ shuffling in John P. Gaines; but when the interest of the people or the good of the country is at stake, the people may rely with confidence that they have an individual to represent them, who is as firm and immoveable [sic] as the hills of his own Kentucky. . . [B]e it remembered that at the age of . . 17 [Gaines] shouldered his rifle and made his way to the tented field to meet the enemy of his country... He has represented his county in the

\footnotetext{
20 Ibid., May 31, 1845, p. 2.

21 lbid.

22 lbid.
} 
Legislature . . . with honor, and distinguished himself as an able and efficient member. In private life Mr. Gaines has ever sustained the character of an upright, honorable gentleman; a man of the strictest probity and honor, and one who scorns and detests a dishonorable action. . . Such, fellow citizens . . is the man who has been unanimously chosen as the Whig Candidate for Congress, for the 10th Congressional District." ${ }^{23}$

Gaines ran against Colonel John W. Tibbatts, Democrat, also known as a member of the Locofoco party. ${ }^{24}$ The two candidates debated several times during the campaign, including confrontations in Mason County, Kentucky, during the first and second weeks of June 1845. The Licking Valley Register sometimes relied upon its "friends" for first hand accounts of the debates. In the June 7, 1845, edition of the Register, a citizen described the debate held in Burlington, Kentucky, that kicked off the campaign. Colonel Tibbatts ran on experience and his reputation as a lawyer. Gaines, also a lawyer, ran as a "plain, good old fashioned farmer," ${ }^{25}$ opening his campaign by stating his candidacy was not of his choosing, but rather that of his friends. In reviewing the debate, the Register's correspondent told readers, "You may rely on it, that the friends of the farmer, were highly delighted with his effort. In candor, I believe Mr. Gaines triumphed."26

On Friday, June 6, and Saturday evening, June 7, 1845, the two politicians squared of in debate over "Tariff, Texas, and Western Waters," in

\footnotetext{
23 Ibid., June 28,1845, p. 2.

${ }^{24}$ Originally formed from a radical wing of the Democratic party, on October 29, 1835, in New York, the Locofoco party crusaded against privilege, the protective tariff, paper money, banks, and corporations.

${ }^{25}$ Licking Valley Register, June 28, 1845, p. 2.

${ }^{26}$ Ibid., June 7, 1845, p. 2.
} 
front of large audiences. According to the Register's correspondent, Tibbatts gave a "genuine democratic, tariff, anti-tariff" speech: He was for a discriminating revenue tariff which would "afford incidental protection," yet "he believed duties upon articles were burdens upon the consumers of the articles, and he was in favor of modifying the tariff of 1842." Gaines, on the other hand, clearly supported the tariff of $1842 .{ }^{27}$ He pointed out inconsistencies in the Colonel's statement on the tariff:

"He showed that Mr. [James] Buchanan whose opinions had been quoted with approbation by Col. T[ibbatts], had voted for this same Tariff Act which the Col. Denounced as abominable, and that the real position of the Locofoco party . . . was hostility to the Protection of American Industry." ${ }^{28}$

When debating the issue of federal aid for deepening rivers and building canals, Tibbatts, known as the "father of western waters," told the audience of "his friendship and exertions on behalf of the Western Waters." Gaines said he would do what he could for Western waters and navigation; however, he "feared he would not be able to effect as much as the Colonel." He reminded the audience that Tibbatts and his party opposed further improvements on the Western waterways. Further, he pointed out that Tibbatts consistently voted "in direct opposition to the known wishes of the people of Kentucky" in this regard. ${ }^{29}$

Tibbatts stated "that if he was elected, he would be a thorough-going Texas man. .." Gaines had opposed the Tyler treaty annexing Texas because

\footnotetext{
27 Ibid.

${ }^{28}$ Ibid., June 14, 1845, p. 2.

${ }^{29}$ Ibid.
} 
". . . annexation under it would impose a debt upon [the United States] of from 10 to 100 millions of dollars, and he doubted the power of Congress to pass the joint resolution. He did not believe such powers existed under the Constitution. .." Nonetheless, Gaines stood for his country whether in the right or in the wrong. This patriotic position took the wind out of Tibbatts's opening address and seemed to place Gaines in the forefront of the campaign ${ }^{30}$ An editorial in the Register on Saturday, June 14, 1845, declared Gaines "a better reasoner, a more profound thinker, a clearer and more interesting speaker than Col.

Tibbatts." ${ }^{31}$ Despite the strong support of his friends at the polls, Gaines lost the election to Tibbatts.

During the nineteenth century many men attained political grandeur through the military: men like William Henry Harrison, who attained the rank of general during the War of 1812, and Zachary Taylor and Joseph Lane, who both gained politically during the Mexican War. In May 1846, during the Mexican War, Gaines volunteered his services for one year to the Kentucky Cavalry, serving in the rank of major. After much difficulty, including his capture and imprisonment as a prisoner of war and making a daring escape, Gaines joined General Winfield Scott as a volunteer aide-de-camp. While he served in Mexico, his peers in Kentucky elected him as their representative in Congress. ${ }^{32}$ When

\footnotetext{
${ }^{30}$ lbid.

${ }^{31}$ Ibid.

${ }^{32}$ Major John P. Gaines, Circular Letter from Major John P. Gaines, of Kentucky, to His Constituents of the Tenth Congressional District (Washington, DC: Towers). This document has no date; however, since Gaines solicited letters of support from his fellow soldiers, I have been
} 
Gaines returned from Mexico he received a hero's welcome. Judge George

Gilpin Perkins remembers, as a young boy, hearing Gaines speak at the Baptist

church in Burlington, Kentucky.

"Major Gaines was the soldier idol of our people and was my ideal over all the other heroes of the Mexican War, for I was old enough then and mindful enough of the war news that absorbed public attention and talk, to gather and grieve over Major Gaines becoming a prisoner of war and subject to its dangers. That was a great blow to me. While still in a Mexican prison he was taken up by acclaim as a candidate for Congress and defeated the popular and powerful General Desha, of Harrison County, in a warmly fought and most exciting contest. The prime emotion and glorification of my boyhood was when he came home from the war and his imprisonment and addressed the people in the big Baptist Church in Burlington. I was there early but the inside of the church was crammed and the outside surrounded. I crowded myself in and edged myself through the crowded aisle to the front of the church and beheld for the first time the bronzed face and lithe figure of the soldier who had suffered and achieved so much. The tingle of the moment when he mounted the dais of the big church and when he told of the bravery of the Kentucky troops and proclaimed his devotion to the State and his love of its people, awakens in me now a still vivid memory which takes me back to the thrilling scene." ${ }^{\text {33 }}$

The Kentucky Legislature commended Gaines and his peers on March 1, 1848,

able to place its date at approximately late spring or early summer of 1848 . This would also coincide with the Thirtieth Congress, in session at the time. The handwritten versions of the letters are in the Gaines Papers (microfilm, reel one). In The Gaines Diary: Mexico, Gaines relates his experiences in the Mexican War up to the time of his capture at Encamation. Other contemporary accounts which tell of Gaines's ordeal and bravery while in Mexico include Winfield Scott, Memoirs of Lieut. General Scott, LLd. (New York: Sheldon \& Company, 1864), John A. Scott, Encamation: or, the Prisoners in Mexico: Being an Account of Their Capture, Treatment, and Travels, (Louisville, Kentucky: G. H. Monsarrat \& Co.'s Steam Press, 1848); and Edward D. Mansfield, The Mexican War: A History of Its Origin and A Detailed Account of the Victories Which Terminated in the Surrender of the Capital; With the Official Dispatches of the Generals, (New York: A. S. Bames \& Co., 1850). The Report of the Adjutant General of the State of Kentucky Mexican War Volunteers (Frankfort, Kentucky: John D. Woods, 1889), pp. 2-3, gives Gaines's rank as Major and third in command of the First Regiment of the Kentucky Mounted Volunteers (also known as the Kentucky Cavalry). Further, this report lists Gaines's muster-in date as June 9, 1846, and his muster-out date as June 8,1847 . It also notes Gaines became a prisoner of war in Mexico on January 26, 1847.

${ }^{33}$ George Gilpin Perkins, A Kentucky Judge (Washington, D. C.: no publisher given, 1931), pp. 26 $-27$. 
for their service to the state and nation during the Mexican War:

"Resolved, That Major John P. Gaines, Capt. Cassius M. Clay, Lieut. George Davidson, and their thirty companions in arms, who were taken prisoners by a force of three thousand Mexicans, under command of Gen. Minon at Encarnacion, deserve the thanks of the people of Kentucky for their bravery, and for their cool determination to maintain the reputation of Kentucky, when escape was impossible, and destruction inevitable, save by a surrender." ${ }^{34}$

On the same day, Gaines also received a commendation for his escape and service with General Winfield Scott:

"Resolved, that Maj. John P. Gaines has won the admiration of the people of Kentucky, by honorably withdrawing his parole as a prisoner of war, when ordered by Gen. Lombardini to go to Toluca; by his escape through the lines of the enemy; by his successful junction with the American army, and by his gallant bearing at Churbusco, Chapultepec, and all the battles fought before the walls and in the city of Mexico--he being the only volunteer from Kentucky who participated in the achievements of Gen. Scott and his army in those memorable victories." ${ }^{35}$

On Friday, December 10,1847, the Thirtieth Congress convened.

Delayed by the war, Gaines took his oath to support the Constitution of the United States, as a representative from the State of Kentucky, on January 5, 1848.

Almost immediately he introduced a petition for "Silas $\mathrm{H}$. Hill and other members of the City Councils of Washington, in the District of Columbia." The petition implored Congress to abolish the slave trade in the Nation's Capitol, or at least to empower the officials of Washington City and Georgetown to make laws to that effect. $^{36}$ Other members in the House Chamber immediately voiced objections to

\footnotetext{
${ }^{34}$ Collins, page 55 .

35 Ibid.

${ }^{36}$ The Congressional Globe: Sketches of the Debates and Proceedings of the Second Session of the Thirtieth Congress (City of Washington: Blair \& Reeves, 1849), p 323.
} 
the petition's reception. The maneuvering back and forth began with Alexander H. Stephens, of Georgia, who moved for an adjournment of the House. Gaines then moved that the rules of the House be suspended, enabling him to present the bill. ${ }^{37}$ The maneuvering continued until Gaines, proceeding cautiously, asked for the privilege to withdraw the petition and gave notice he would present it under the rules. Since the House did not have possession of the petition, Gaines obtained permission to withdraw it. ${ }^{38}$ This episode demonstrates Gaines's political position regarding the slave trade.

While there is no evidence that Gaines actively purchased slaves, or that he condoned the institution of slavery, he did possess slaves before departing Kentucky. It is possible he inherited them from his father or through his marriage to Elizabeth Kinkead. Nevertheless, upoil leaving Kentucky, he sold all of his property including "land, [N]egroes, and personal property, attached to the farm" - in effect leaving it all behind to start a new life in Oregon. ${ }^{39}$ There is some speculation Gaines brought slaves with him around Cape Horn; however, none of the Gaines family diaries or other family papers mention slaves traveling with the family to Oregon. Further, contemporary newspapers give no evidence of slaves arriving in Oregon with the family. Surely, at a time when the issue of slavery

\footnotetext{
${ }^{37}$ Ibid.

38 Ibid. While I have found no evidence that Gaines ever actually presented the petition under the rules, it is interesting to note that the Compromise of 1850 contains a similar provision to abolish the slave trade in the District of Columbia, and that the sponsor of this provision was Abraham Lincoln.

${ }_{39}$ Archibald K. Gaines Joumal, p. 2. The sale of property to his brother, A. K. Gaines, amounted to over $\$ 14,000$, part of which John Gaines received from his brother over a two-year period.
} 
excited debate in Oregon and elsewhere around the nation, local newspapers

would have scrutinized a slave-holding governor. Further, in a region where the

inhabitants wanted neither slave nor free black people, one should find some

commentary upon Gaines in the local press if individuals of like nature arrived

with him from Kentucky. ${ }^{40}$

${ }^{40}$ Ibid. Cathy Beckham, “Jestens' English-Style Cottage Is Open to Visitors Sunday," The Oregon Statesman Capital Joumal, (September 30,1978), section B, p. 1. This article is about the old Gaines donation land claim and home near Salem. I question the authenticity of some of Beckham's information. She opens with "Gone and forgotten are those house and field slaves brought west from Kentucky around the Hom by Oregon's temitonal govemor, John P. Gaines. Today they rest in unknown graves. . " I have found no evidence to support the statement that there were slaves with Gaines when he came around Cape Hom. On the contrary, Gaines sold slaves when he left Kentucky; however, there is evidence that servants accompanied Gaines and his family around Cape Hom. (See Gaines Papers, letter to Commodore Jones, U. S. store ship Supply, San Francisco, July 19, 1850, reel 3, Box 6, folder 1, frame 00436.) In 1885, an unknown individual who purports to have known Gaines well, states, "I have a pleasant memory of Govemor Gaines, who was a fine type of Kentuckian, and came to Oregon to remove his family from the evils of slavery. I was well acquainted with him and visited occasionally his beautiful home in the hills, about seven miles south of

Salem...." (See "Pioneer Days: Reminiscences of One of Oregon's Teritorial Govemors, John P. Gaines," The Moming Oregonian, July 26,1885 , page 3.) It is possible the servants accompanying Gaines and his party were not black at all and therefore not subject to commentary. In his "Bits for Breakfast" column (Oregon Statesman, August 29, 1929, p. 4) R. J. Hendricks comments upon the Gaines home in Salem as extending "a good many feet in the east, in additions that were occupied by the Gaines slaves; probably an inheritance from Mrs. Gaines. The tradition is that the Gaines slaves were freed when the govemor came to Oregon. Also, the old timers say, at least two of those negro [sic] slaves died there and are buried on the place." If servants did accompany the Gaines family, and they were black individuals, then, given the time period, perhaps there is some basis for both Hendricks's and Beckham's assumption they were slaves. At least this, in part, explains where Beckham got her information. While Hendricks relates his account as the remembrance of "old timers," the question still remains -- why is there no further comment in any of the Gaines family papers about freed slaves coming with them to Oregon? Further, if there were, in fact, black individuals accompanying the Gaines party, slave or servant, then why, at sometime during Gaines's tenure as govemor, did Asahel Bush not comment upon this fact in the Oregon Statesman? Hopefully, further research will uncover the answers to these questions. Beckham also presents Gaines as "a retired army captain" instead of a Major in the Kentucky Cavalry. She also lets the reader believe Gaines moved to Salem upon his amival in August of 1850 and "lived there as he ran the state. . " Gaines did not actually move to Salem until well into his term and after Salem became the capitol of the temitory; before that time his place of residence was Oregon City. Further, Oregon did not become a state until after Gaines's death. On the other hand, Beckham relates some interesting tidbits of information for her readers. For example, she states that a slippery elm tree on the property grew "from seeds taken from Mt. Vemon. .. " and that a big fir tree on the property once had horses tethered to it, producing a ring which had since "been swallowed up over the years by the bark." Perhaps instead of doing 
Gaines attempted another term in Congress in the spring of 1849 , running against Colonel Richard H. Stanton. The two candidates debated, during May and June, the improvements of western rivers and harbors: Gaines "avowed himself in favor of appropriations" for the improvements; Stanton chose to be "non-committal on the subject of western improvements," taking the "middle ground by which the west would never get a dollar. ${ }^{41}$ When debating the territorial question, Gaines explicitly oppcsed the "application of the Wilmot proviso" favoring instead to leave "the determination of the slavery question to the People of the Territories.." ${ }^{42}$ Stanton agreed, but "contended that any compromise would be unconstitutional," adding that "if the People of the Territories are not permitted to decide the question for themselves, the South must insist upon having the whole as slave territory." ${ }^{43}$ Gaines's "efficient services in legislative halls and in the tented field" ${ }^{\prime 4}$ lend to his confidence in his victory, however, when election day arrived in September of 1849 , Stanton defeated him by a very small margin. ${ }^{45}$

A comment made by Delegate Samuel Thurston, regarding Congressional appropriations for the Oregon Territory, brought Gaines back to the present. It

research on Gaines, Beckham relied upon information passed from property owner to property owner long after the Gaines family departed the South Salem farm. Unfortunately, a majonty of newspaper articles and histories prejudice Gaines with this type of unsubstantiated information, which propagates further erroneous and non-factual background conceming his life in Oregon.

41 The Covington Joumal, June 15, 1859, p. 2.

42 Ibid

43 Ibid

44 Ibid.

45 Ibid., September 7,1849, p.2. Stanton won by a mere 364 votes. 
had been a few months now since his defeat in the campaign for Congress. He had left behind his beloved home state, friends, and family. Now he and his immediate family were about to embark on a journey to a land far away and unknown to them.

During their meeting Gaines, Thurston, and Taylor discussed the appropriation of $\$ 5,000$ for a territorial library, of which amount Gaines would spend $\$ 3,000$ purchasing books at New York to take with him to Oregon -- the remainder having already been expended. Congress dedicated another $\$ 5,000$ to public buildings for the territory, and $\$ 20,600$ for expenses of the Oregon Legislature's first session. ${ }^{46}$ The president requested Gaines to carry the drafts with him around the Horn to pay the legislators for their expenses. Thurston objected, "on the ground it would not reach Oregon until next July, and urged the draft or drafts be drawn ... on the custom houses at Astoria and San Francisco for the amount, so that the members of the last legislature might receive their pay as soon as possible." Gaines and Taylor both agreed. ${ }^{47}$

The men also debated the new governor's mode of transportation to the Pacific Coast. One possibility discussed was sending the U. S. Store Ship Supply from New York around Cape Horn and on to Astoria after unloading its freight at San Francisco. After a short debate on this matter, Taylor assured Gaines and Thurston he would issue an order for the Supply to take the party to

${ }^{46}$ Thurston Diary, p. 156.

47 Ibid. 
San Francisco, and a separate order for it or another vessel to carry them from that point to Astoria. The three men covered a few more details, then adjourned their meeting. After the president left, Gaines and Thurston continued to discuss matters relating to Oregon until midnight, at which time both men retired to their rooms, promising to see each other on the following day. ${ }^{48}$

At a brief meeting on December 2, Thurston and Gaines agreed to meet with the Secretary of the Treasury the next day. Instead, they met with the First Comptroller of the Treasury and discussed matters "relative to ordering the Collector at Astoria to pay off the members \&c of the last Legislature." They also met with the Secretary of the Navy regarding the store ship Supply and its course to the Pacific with Gaines and his party. Finishing this business, Gaines and Thurston returned to the hotel, commencing once again in a discussion about the people and the situation in Oregon. They bid each other goodnight in the early morning hours of December $4,1849 .{ }^{49}$

On December 21, Gaines met with Thurston a last time before departing for New York. They met immediately after breakfast at Gaines's hotel room and proceeded to the Postmaster General to discuss the appointment of a mail agent in Oregon. After this final meeting, Gaines returned to his room at the hotel in Washington City. He sat at a desk, considering the suggestions made by Thurston and Taylor regarding the people of Oregon and his role as governor of

\footnotetext{
48 Ibid., pp. 156-157.

49 Ibid., p. 158.
} 
the Territory. Before he retired he compc.sed a letter to the president:

"Sir

Previous to my departure [for the]Territory of Oregon. . . with my family, and over which by your partiality, I have been [called] upon to preside, I desire to present to your consideration, such [information] as I have been able to obtain from reliable sources of the wants [and] wishes of my fellow Citizens in order that Congress anticipate its action, the time which must necessarily intervene before 1 [can] communicate anything from my own personal observation. . ."50

Regarding land for immigrants in the Oregon Territory, Gaines reviewed the organization of Oregon's Provisional Government and its Act which required a section of desirable land be donated to "each Male citizen of eighteen years and upwards ..." His concern centered around land speculators who preyed upon settlers, advancing them money or purchasing the land through what appeared to be an act of "good faith." In reality, the speculators committed "only a miserable subterfuge, deception and fraud," leaving the settler with little or nothing of their original investment. ${ }^{51}$ Commending the settlers, Gaines said,

"These men are the pioneers. . and should have and are entitled to every [benefit] it is in the power of the central government to bestow . . . Under such a wise, just, and salutary arrangement the [settler] feels secure in his land which is the first great object of his mind, his improvements will be more cheerfully and rapidly made, for he will then know that no rapacious Speculator could wrench it from him and the Country will grow up with actual tillers of the soil and Oregon will thus be peopled with a strong, hardy and industrious race, ready in a few years to increase the wealth [of the] nation, or if necessary to defend its people and its altars from aggressions of enemies. ${ }^{.52}$

Increased immigration West irritated Native Americans -- in the Oregon

50 Gaines Papers, letter to "His Excellency The President of the United States, dated Washington City, December [22, 1849], reel three, box six, folder two, frame 00445.

51 Ibid.

52 Ibid. 
Country increased settlement resulted in the Cayuse Indian Wars. Settlers organized to defend themselves against the angry natives and, in his letter to President Taylor, Gaines urged approval for the payment of claims incident to the Cayuse Indian Wars. ${ }^{53}$ Moreover, he recommended immediate attention to the negotiation of treaties with the Native Americans residing in the Oregon Territory:

"The Indian is the original owner of all our lands, and as a nation we owe him more [than hardship] and oppression. He should be treated as our friend, and .. . [we should] deal with him as an equal . . he should be made to [understand], and comprehend, that though more powerful than he, [our] strength should be his Safety, and that in all things and [under] all circumstances, he shall regard us as his friend and protector [on] whom he can safely rely, but that for every act of faithlessness or [cruelty], prompt punishment will be inflicted. .."54

Gaines also stressed the importance of passing and enforcing laws against individuals caught selling liquor to Indians, commenting that "instead of striving to elevate [them] from barbarianism to civilization," selling them liquor caused them to "sink . . to the level of the beast."

Because of its remoteness from the rest of the country, the Oregon Territory lacked adequate mail and transportation routes. Gaines realized the growing importance of the Oregon Territory and that its people would have a desire to communicate with loved ones and business associates in the East and Midwestern portion of the United States. Thus, he requested postage rates on letters to the states be consistent with, and no higher than, those within the

\footnotetext{
53 Ibid.

54 Ibid.

55 Ibid.
} 
territory. Further, he noted that increased delivery of the mail to Oregon, "at least ... once every two weeks ...," and immediate improvement of roads within and to the territory, would be of great "advantage to the people of Oregon and the mercantile interest of the nation . ..."56 Moreover, Gaines cited needed improvements in transportation on the territory's rivers and "[P]acific [C]oast, particularly at the mouth of the Columbia and Willamette." He suggested ports of entry be designated, "the most prominent of which would seem to be the [Port of] Portland, it being the nearest point to the City of Oregon accessible to large vessels." ${ }^{157}$

Money for the territory's government, buildings, and defense also appeared among Gaines's top priorities. He encouraged President Taylor and Congress to make their appropriations to the Oregon Territory "as liberal as possible, with a due regard to [the] high price of labour and material in the Country." Again, the remoteness of the territory weighed heavily on his mind. "[With] the great extent of the coast and still more extended frontier constantly exposed, the great distance from Washington, and the difficulty of rapid communication, it will be seen that emergencies may arise when it will be necessary for the Territory to meet dangers, and incur expenses. ${ }^{n 58}$

Thus, he requested liberal funding to build roads, military posts, and maintain "a suitable number of troops."

${ }^{56}$ Ibid.

57 lbid.

58 lbid.

59 Ibid. 
Gaines intentionally. "avoided asking any special appropriations" because of his limited knowledge of Oregon and its people. He presented only the "most prominent and immediate" needs brought to his attention. In closing his letter, he suggested to President Taylor that if he and Congress believed the recommendations warranted, "it would oblige the people whose interest I desire to serve."60

60 Ibid. 
Chapter Two

\section{SLAVERY, ECONOMIC DEPRESSION, AND MANIFEST DESTINY}

"The movers, like the Romans, carried with them their lares and penates, their peculiarities and their prejudices, their customs and their political institutions. This intellectual baggage, however, did not always arrive intact. Some of it, impractical and therefore expendable, would be discarded along the way. Some would be altered, roughened by coarse circumstances."

On November 4, 1847, the Smith family pulled their raft out of the Columbia River. A cold rain, with snow on the mountains close by, made conditions almost unbearable. Climbing a steep hillside they built a fire, attempting to cook and warm themselves and their children. The wind blew cold around them and the Columbia churned below. Placing their raft in the turbulent water, the party moved a few miles on November 7 , but the storm again forced them to land. Icicles hung from the wagon beds into the water. Elizabeth Smith was so cold she could barely write in her journal. She attempted to warm herself by the fire but smoke filled her eyes and the heat burned her clothing. Her family found plenty of wood to burn, but the wind blew away the warmth it generated. Their provisions were dangerously low which forced Elizabeth's husband to leave in search of food. After several more attempts to navigate the Columbia the Smiths finally made it to the falls on November $11 .^{2}$ Two weeks later, after ferrying their cattle across the

\footnotetext{
1 Malcolm Clark, Jr., Eden Seekers: The Settlement of Oregon, 1818-1862 (Boston: Houghton Mifflin Company, 1981), p. 180.

2 "The Journal of Mrs. Elizabeth Smith Geer," as cited by Fred Lockley, History of the Columbia River Valley: From The Dalles to the Sea, Vol. I (Chicago: The S. J. Clarke Publishing Company, 1928), pp. 803-807. Elizabeth Smith is probably referring to Celilo Falls.
} 
mighty river and back again to avoid the falls, they passed Fort Vancouver. Then, on November 29,1847 , the Smith family landed at Portland by way of the Willamette River. Elizabeth Smith's husband died two months after their arrival. ${ }^{3}$ Her harrowing ordeal is typical of that experienced by hundreds of immigrants traveling to the Oregon Country -- a hardy, self reliant group of individuals.

Among the immigrants traveling overland, some chose to travel the final leg of the journey over the Blue Mountains to The Dalles and down the mighty Columbia River. Some individuals followed adventurers like Stephen Meek who attempted to bypass the Blue Mountains and locate a better route into the Willamette Valley. Meek's disappointed followers ended up at The Dalles during the winter of 1845 . Those who desired to avoid the treacherous Columbia joined Samuel Barlow's party in seeking a safer route into the northern end of the valley. Another route took immigrants around Cape Horn to the Pacific Coast. This route proved to be just as onerous and difficult as the overland routes.

Many immigrants leaving the United States before the Civil War embarked on the long journey West - either across the plains or around Cape Horn - to escape the growing social and political pressures connected to the slavery issue. 
Slavery, in nineteenth century America, was a societal institution based on ownership, dominance, and the exploitation of one human being by another. That slavery was a profitable enterprise is evident in its enormous growth during the nineteenth century. The material and ideological differences between northern and southern states provided a potentially dangerous situation. Although slave markets existed in both the North and South, an increasing number of individuals regarded slavery as unnecessary and undesirable. The rise of antislavery sentiment represents a surge in the feelings of sympathy, guilt, and anger. Politics became inextricably mixed with the slavery issue in the years after the Missouri Compromise (1820-21), by which Maine entered the Union as a free state and Missouri as a slave state; however, the Compromise prohibited slavery in the rest of the Louisiana Purchase territory -- above the thirty-six degrees thirty minute line. Southern leaders feared their power in the House of Representatives would dwindle with the creation of new free states. Senators resisted by calling for a southern slave state to balance every free northern state and by upholding the ideas of state sovereignty and the sanctity of private property--including slaves.

In 1845 , these issues again became paramount in the debates over the annexation of Texas and the Mexican War, by which the United States acquired a large block of territory not affected by the Missouri Compromise. 
This territory lay outside the scope of the Louisiana Purchase, and therefore became a battle ground both politically and through the act of war against the area's former occupants. Unsuccessful at opposing the annexation and the war, antislavery forces sought to bar the extension of slavery into new territories through the Wilmot Proviso of 1846 , by which new territories would be open only to the white population; however, the proviso failed to secure the desired results in a satisfactory manner.

As the northern antislavery movement changed its tactics from direct political action--for example, attacks on slavery in the state legislatures--to general moral condemnation of all Southerners, southern attitudes began to set. In the early 1830 s the South had claimed the largest number of antislavery societies; by the mid-1850s all such societies were north of the Mason-Dixon Line. ${ }^{4}$

\footnotetext{
${ }^{4}$ For further reading on the issue of slavery, territorial expansion, and the development of party politics see Thomas Brown, Politics and Statesmanship: Essays on the American Whig Party (New York: Columbia Press, 1985); Ronald P. Formisano, The Birth of Mass Political Parties: Michigan, 1827-1861 (Princeton: Princeton University Press, 1971); Eugene Genovese, The World the Slaveholders Made (New York: Vintage Books, 1969); Eugene Genovese, Roll, Jordan, Roll: The World the Slaves Made (New York: Pantheon Books, 1972); Thomas Haskell, "Capitalism and the Origins of Human Sensibility, American Historical Review, 90 (April and June, 1985), 339-361, 547-566; Michael Fitzgibbon Holt, Political Parties and American Political Development: From the Age of Jackson to the Age of Lincoln (Baton Rouge: Louisiana State University Press, 1992); Richard L. McCormick, "The Party Period and Public Policy," Journal of Amerrican History, LXVI, (1979), 279-298; Michael A. Morrison, "New Territory Versus No Territory: The Whig Party and the Politics of Western Expansion, 1846-1849," The Western Historical Quarterly, 23 (February 1, 1992), 25-51; Michael Morrison, "Westward the Curse of Empire: Texas Annexation and the American Whig Party," Journal of the Early Republic, 10, (Summer 1990), 221-249; and Robert V. Remini, Henry Clay: Statesman for the Union (New York: W. W. Norton \& Company, 1991).
} 
The institution of slavery, which promulgated distinctive political, ideological, and social behavior, also had economic ramifications. The conflicts over slavery coupled with world-wide economic changes caused many bank failures during the late 1830 s. A severe depression hit the country between 1837 and 1841. During the 1840 s rampant inflation, crop failures, and wild land speculation caused many citizens to lose their homes and property. Along with the economic disasters came disease and pestilence. The hopelessness of the situation at home in the United States caused many citizens to look elsewhere for a better life.

In early 1850 , attempting to appease both Northern and Southern interests, Henry Clay designed several measures which, after much debate in Congress, became the Compromise of 1850 . The final version of the Compromise consisted of five acts whereby California entered the Union as a free state; Texas and the United States established a boundary at the Rio Grande, and the Republic of Texas agreed to relinquish its claim to half of modern-day New Mexico and portions of Colorado, Wyoming, Oklahoma, and Kansas, in exchange for the assumption of its ten million dollar debt by the federal government; New Mexico and Utah became territories with the ability to enter the union as either free or slave holding states; the slave trade (but 
not slavery) became illegal in the District of Columbia; ${ }^{5}$ and the South gained a stricter fugitive slave law.

The second quarter of the nineteenth century witnessed a great burst of westward migration. Individuals, driven to improve their situation, promoted the idea of Manifest Destiny. Manifest Destiny, the term coined by John L. O'Sullivan, became the American mission -- the American dream. If individuals could not provide for their families in the United States, then they would search elsewhere for the land of opportunity and they would bring with them their democratic ideals. Fur traders, missionaries (sometimes unwittingly), and politicians promoted the Oregon Country as the promised land of new beginnings.

Samuel Barlow was among a multitude of immigrants who supported the United States's claim to the Oregon Country. Moreover, a majority of immigrants sought a better future for their children in the West.

Disappointment over Henry Clay's loss in the presidential election of 1844 and a growing concern over the issue of slavery also motivated Barlow's move west. ${ }^{6}$ The Barlows began their trek west at a time when Americans raced to beat their British rivals in settling the Pacific Northwest. In the early

\footnotetext{
${ }^{5}$ It is interesting to note that in early 1848 John Pollard Gaines attempted to introduce a bill in Congress to abolish the slave trade in Washington City. See The Congressional Globe: Sketches of the Debates and Proceedings of the Second Session of the Thirtieth Congress (City of Washington: Blair \& Reeves, 1849), p. 323.

Dale Morgan, ed., Overland in 1846, Volume II (Georgetown, California: Talisman Press, 1963), pp. 246-248.
} 
years, immigrants entered an Oregon Country jointly occupied by the United States and Great Britain; however, neither nation truly governed the inhabitants. After France and Spain surrendered their claims to the region the United States and Great Britain negotiated an agreement in the Convention of 1818. As part of this agreement, the British and the Americans drew a boundary at forty-nine degrees north between British North America and the United States. The boundary began at the Lake of the Woods (in present-day Minnesota and Manitoba) and ended at the Continental Divide, leaving the Oregon Country open to joint occupation. This understanding became known as the Joint Occupancy Agreement.

Ewing Young, a prominent settler in the Willamette Valley, died in 1841 leaving no will directing the disposal of his estate. Young's death provided the impetus to form a local government in Oregon -- the settlers realized the need to form a government to handle such matters. They held a series of meetings, between 1841 and 1843, resulting in Oregon's Provisional Government. This government represented its citizen's strong desire for self-government, the belief in the agrarian way of life, and Manifest Destiny. ${ }^{?}$

The British--especially those involved in fur-trapping ventures--felt threatened by the ever-increasing tide of American emigrants after 1843. The United States demanded a new boundary be drawn at the fifty-four degrees

7 For further reading on Oregon's Provisional Government see John A. Hussey, Champoeg: Place of Transition (Portland: Oregon Historical Society Press, 1967). 
forty minute line; the British were willing to compromise at forty-nine degrees north because of the diminishing fur trade south of the Columbia River.

John M. Shively, an immigrant of 1843 , returned to the States hoping to publish an emigrant guide to urge other Americans to settle in his newly platted community near what is now Astoria. While on the East Coast, Shively visited with representatives of both the United States and Great Britain. He recommended both countries withdraw their claims of title, "allowing Oregonians to govern themselves for a period of five years, at the end of which time a plebiscite would determine whether the country would be British, American or independent." ${ }^{8}$ He based his recommendation on the argument that distant governments would provide nothing but ineffective governing. Shively is representative of Oregon immigrants and their strong sense of independence. The settlers of the region learned to conduct business without the benefit of either country's government. As a result they came to resent outside interference -- especially when it came to government officials.

In 1844, upon becoming president on a platform of territorial acquisition and a slogan of "Fifty-Four-Forty or Fight," James K. Polk continued the agenda of territorial acquisition for the United States. The arrival, settlement, and increased population of American citizens in the Oregon Country helped to enable the United States to acquire it free and clear of other European claims. ${ }^{9}$

${ }^{8}$ Clark, p. 187.

${ }^{9}$ Ibid. 
Polk walked a thin line when it came to negotiating the boarder of the Oregon Country with Great Britain. He made the Oregon boundary issue a large one in his campaign for president, yet his real desire was to expand the boarders of the United States into Mexico. The Mexican War complicated the issue -- Polk did not want the controversy with Great Britain over Oregon to interfere with his designs on southern expansion. Further, there was at that time a large peace coalition in Congress that did not want a war fought over Oregon and were well aware of Great Britain's naval warfare capacity. So, when Polk sent notice to Great Britain that the United States desired to terminate the agreement of 1827 and open boundary negotiations, Great Britain responded with an offer of a proposed boundary at the forty-ninth parallel. Further, the British asked that the Hudson's Bay Company (but not British nationals) be allowed to navigate along the Columbia River south of the boundary. Polk asked his Cabinet for advice regarding the British response, and the Cabinet in turn sent the proposal to the Senate. The Senate advised that the offer from the British be accepted. Thus, President Polk accepted the British proposal of a boundary at forty-nine degrees in 1846 , ordering a treaty be drawn and ending the Joint Occupancy Agreement. $^{10}$

With the end of Joint Occupancy, a sharp increase in migration to the Pacific Northwest resulted in new overland routes being opened, improving

10 For further information on the Joint Occupancy Agreement, see Frederick Merk, The Oregon Question (Cambridge: The Belknap Press of Harvard University Press, 1967). 
access into the Willamette Valley. Jesse Applegate, who built the southern route into the valley, cites "the year 1846 [as] an epoch to be remembered in the history of Oregon, for the quiet settlement of its boundary, [and] for the arrival of emigrants from the United States with their wagons, at both ends of the Willamette [V]alley. ..."

Located on the West Coast of the continent, Oregon remained remote from the arm of the United States government. Being ruled by the federal government of the United States did not interest Oregonians; yet they desired protection from foreign interests, such as the British based Hudson's Bay Company. Growing trouble with local Indian tribes also caused anxiety among the newcomers. While the Natives of the northern Willamette Valley tended to be friendly, others resented the settlers' presence. They had learned, from their brothers to the East, about the invasion of the native homeland. This alarmed the Native Oregonians: Why did these newcomers wish for them freely to give up their land and customs? The conflict between the Natives and early Oregon settlers focused federal government attention on the frontier of the Far West. Justification for making Oregon an official territory of the United States, entitled to federal military protection, came as a result of the Whitman Massacre on

\footnotetext{
${ }^{11}$ Jesse Applegate, Oregon Spectator, January 21, 1846, cited by Dale Morgan (ed.), Overland in 1846, Volume II (Georgetown: Talisman Press, 1963), pp. 69-70. This reference is from part one of a series of articles written by Jesse Applegate for the Oregon Spectator between January and April 1847. Applegate used an " $X$ " for his signature in these articles.
} 


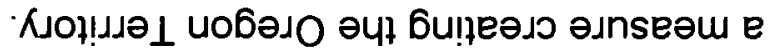

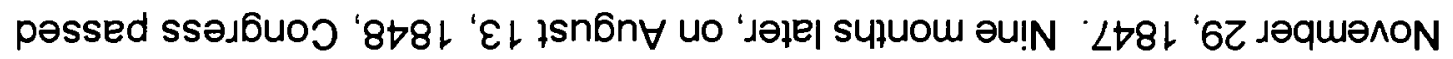


Chapter Three

\section{A NEW TERRITORY, ITS OFFICIALS, AND PARTISAN POLITICS}

"It is now made certain, that a [W]hig press is on the way for Oregon, to be established at Portland . . It is also certain, that Marion \& Clackamas Counties, the two heaviest counties in the Territory, have drawn the lines \& organized accordingly, and this will probably be the case, all over the Territory, very soon ..."1

At first glance the territories of the United States appear to resemble the colonial form of government used by Great Britain: the central government ruled them from a distance. Yet, when examining the American form of territorial government closer, one will find differences, presumably made by early politicians to correct "recognized abuses in the English system." From 1780 until 1802, the original states of the Union made several cessions creating new territories northwest of the Ohio River. This created the issue of disposing of the territories in such a manner as to produce the "greatest degree of happiness to their inhabitants." ${ }^{3}$ As a result, the government of the United States began debating a policy of administering the new territories for the benefit of all its citizens.

Before 1780 , the interests and activities of speculators of western lands influenced the debates in Congress over whether territories in the West should

\footnotetext{
1 "Political Correspondence Asahel Bush II from Samuel Thurston," (transcribed), A-3-tt, \#2. Housed at Portland State University Library. No fage numbers. Citation is dated Washington, August 11, 1850, and labeled Confidential.

2 Elvin L. Valentine, "The American Terntorial Govemor," (Graduate School, University of Wisconsin, July 2, 1928), p. 7.

3 T. C. Hinckley, ed., Studies in Temitorial History (Manhattan, Kansas: Sunflower University Press, 1981), p. 3.
} 
come under state or federal control. Opposition to the cession of lands came from "land companies with political ties to states possessing western claims."

Those with economic and political ties to the landless states, who "in disregard of state claims were making purchases on their own from the Indians," desired the United States to maintain control of these lands. ${ }^{4}$

In October of 1783 , Congress thought it prudent to create a "district of the western territory." Thomas Jefferson served as chairman of the committee formed to devise a plan for a government which would connect the people of the West with the United States. To Jefferson,

" . . . as to most contemporary believers in natural-law concepts, it was axiomatic that governments derived their legitimate authority from the consent of the governed, and that this consent was given, in theory if not in historical fact, by the people's entering in to a primordial social compact, which was then continuously renewed through the tacit acceptance of succeeding generations." 6

Even though Jefferson's committee did not fully realize its goal, the ideal became the basis for "a firm central control of the West." A few years later, following a tour of the Northwest Territories, James Monroe addressed short-comings in the Ordinance of 1784 -- specifically, the size of the new territories and population requirements for statehood. ${ }^{8}$ After considering Monroe's recommendations in

\footnotetext{
${ }^{4}$ Arthur Bestor, "Constitutionalism and the Settlement of the West: The Attainment of Consensus, 1754-1784," ed. John Porter Bloom, The American Teritorial System (Athens, Ohio: Ohio University Press, 1973), p. 19.

5 Valentine, p. 7.

Bestor, p. 24.

Ibid., p. 6.

8 Jack Ericson Eblen, The First and Second United States Empires: Govemors and Temitorial Govemment, 1784-1912 (Pittsburgh: University of Pittsburgh Press), 1968, p. 28.
} 
early 1786 , Congress selected a committee, chaired by Monroe himself, to review the "whole problem of government for the Northwest." Based on the committee's report, Nathan Dane drafted the comprehensive and definitive Northwest Ordinance of 1787 , relating a specific "compact between the Original States and the People" in the territories northwest of the Ohio River. ${ }^{10}$

Through the Northwest Ordinance of 1787 , Congress provided a guideline for territorial governments that carried them through until they became members of the United States. Ideally, the territories would eventually become individual states: members of the federal union yet distinctive in nature. The Ordinance did not allow the settlers to govern themselves to begin with; however, it did guarantee that when territories achieved "a predetermined point in their cycle of growth," they would not only become self-governing, but also members of the Union "on equal footing with the original States, in all respects whatever."11

Congress later added four amendments to the Northwest Ordinance, conforming it to the United States Constitution after its ratification. Of these four, one declared "the President shall nominate, and by and with the advice and consent of the Senate, shall appoint all officers which by the said ordinance were to have been appointed by the United States in Congress assembled." ${ }^{12}$ The

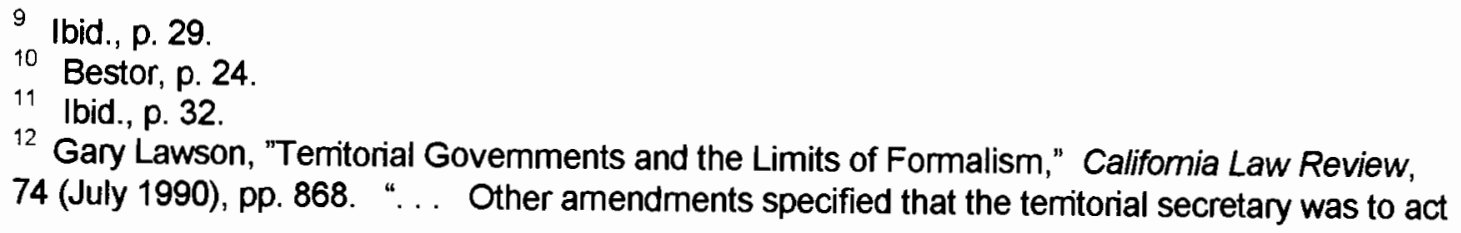


"appointments clause" remained unchanged for 160 years, the first change occurring in 1947 in an "amendment to the Organic Act of Puerto Rico authorizing popular gubernatorial elections. .."13

So, the evolution of a territory consisted of three stages. "Congressionally appointed officials" governed territories in their first stage. During the second stage congressionally appointed officials still governed the territories; however, locally elected legislators and a "nonvoting delegate in Congress" enabled a certain measure of self-governance. Once a territory surpassed the first two stages it could attain statehood, the third and final stage of territorial status. ${ }^{14}$

Territorial governments, as defined by the Ordinance of 1787 , went through two stages of government. The first stage ended when 5,000 "free, adult, male inhabitants" had settled in the new territory. The second stage continued until the territory's population reached 60,000 men, women, and children. ${ }^{15}$ On the average, territorial status lasted approximately twenty years. ${ }^{16}$ During the first stage of territorial government, the control of both general and local affairs became the duty of the governor, secretary, and three judges, appointed by the federal government and responsible to Congress. Local citizens had no voice

in the governor's absence . . . all required reports were to be filed with the President . . . and the President rather than Congress was to exercise the removal power."

13 Ibid.

${ }^{14}$ Robert F. Berkhofer, Jr., "The Northwest Ordinance and the Principle of Territorial Evolution," Bloom, The American Temitorial System, p. 46.

${ }_{15}$ Valentine, p. 3.

16 Oregon became a state after only eleven years of territorial status. 
over the legislative, executive, or judicial branches of territorial governments -nor did they have the right to elect territorial officers. Further, territorial officials received their pay from the federal government. This practice lessened the pressure from local individuals seeking to direct the government contrary to federal laws. Territorial governments still remained aloof from true democratic process during the second stage; however, the territories' male occupants did gain the right to elect members to their territorial legislature.

So, as Oregon's Provisional Government gave way to an official territorial government, the inhabitants of the new territory lost their autonomy to elect those who would govern them. Unlike most territories, however, the citizens of the Oregon Territory retained some measure of control over local governmental affairs. For example, instead of having to wait until the second stage of territorial government, they were able to elect the members of the Oregon Territorial Legislature during the first stage of the territory. Moreover, Oregon's territorial governor did not have absolute veto power of legislation ${ }^{17}$ and could not "dissolve the [Legislative] Assembly at pleasure."18 This ability resulted from early Oregonians' efforts in forming a provisional government before recognition by the United States as an official territory.

President Polk's first choice for Orəgon's territorial governor was James 
Sheilds, who later distinguished himself as a general during the Civil War.

Sheilds declined the post, choosing instead to pursue a career as an Illinois state senator. On August 18, 1848, Polk extended the commission to General Joseph Lane, who accepted a few days later.

At the time of his appointment, Lane, a Democrat, was living at home in Indiana. Born in North Carolina, in 1801, Lane grew up in a frontier state. He attained the rank of Brigadier General and became a very popular leader during the Mexican War. On August 29, 1848, he told his wife and eight children goodbye and left for the Oregon Territory. ${ }^{19}$ Joseph Meek, U. S. Marshall for the territory, and a detachment of twenty-five riflemen, escorted Lane west. President Polk urged Lane to take the shortest and quickest route to Oregon and declare it a territory of the United States under the Democratic administration. Polk and other Democrats wanted the territory opened before the end of his term because "it seemed almost certain that [General Zachary] Taylor, a Louisiana Whig, would

19 For further reading on Joseph Lane see Victoria Case, The Quiet Life of Mrs. General Lane (Garden City, New York: Doubleday \& Company, Inc., 1952); James E. Hendrickson, Joe Lane of Oregon: Machine Politics and the Sectional Crisis, 1849-1861 (New Haven: Yale University Press, 1967); Sister Margaret Jean Kelly, The Career of Joseph Lane, Frontier Politician (Washington, D. C.: The Catholic University of Arnerica Press, 1942); Lane Autobiography (Bancroft Library, 1878) The Lane Autobiography began in the parlor of the Clarendon House in Portland, Oregon on Friday, June 21,1878 . H. H. Bancroft interviewed Lane while a secretary, referred to only as "A. B.," wrote down Bancroft's questions and Lane's answers; Hariet Lane, "General Joseph Lane and His Relation to the History of Oregon Between the Years 1849 and 1853" (Bachelor's Thesis, University of Oregon, 1909); Lena Newton. The Public Career of Joseph Lane (Thesis, University of Oregon, undated); Western, Biography of Joseph Lane (Washington: Congressional Globe, 1852). 
be elected." ${ }^{20}$ Lane and his party traveled overland along the Santa Fe Trail to New Mexico, then on through Arizona to San Francisco, California, where they arrived in February of $1849 .{ }^{21}$ At San Francisco the party boarded the Janet and sailed up the Pacific Coast to Oregon. Also on board the Janet was James W. Nesmith, former justice of the Oregon Provisional Supreme Court, and fellow Democrat. ${ }^{22}$

Arriving in Oregon on March 2, 1849, Lane had only a short time to establish the Oregon Territory under the Democratic Polk administration. A day later, on March 3, 1849, Polk and the Democratic Party left the White House. Then on March 4, 1849, a new Whig administration, led by President Zachary Taylor, made the White House its headquarters. News of this change did not reach Oregon for several months, enabling Lane enough time to set in motion the wheels of government. Under his governorship Oregon took its first census and held its first election. Lane divided the territory into judicial districts, visited numerous settlements, and began negotiations with the Native Americans for

\footnotetext{
${ }^{20}$ Newton, p. 4. Newton cites an article written by Walter Woodward, titled "Rise and Early History of Political Parties in Oregon," which appeared in the Oregon Historical Quarterly in March of 1911. Further, she cites "Conversations with Mr. John Minto, Mr. George Himes, Mr. Asahel Bush, and Mr. [?] Washbume." I have established the fact that Asahel Bush passed away in 1913. Therefore, as far as I have been able to ascertain, Newton probably wrote this thesis in 1912. ${ }^{21}$ Ibid.

${ }^{22}$ Hendrickson, p. 6n, "James Willis Nesmith (1820-1885) was bom in New Brunswick, Canada, and came to Oregon with the overland migration of 1843. Before going to the gold fields in Califomia, he served as justice of the provisional supreme court, member of the provisional govemment, and captain in the Cayuse War. in 1853 he became U. S. marshal, in 1857 superintendent of Indian affairs, and in $1861 \mathrm{U}$. S. senator from Oregon. He was elected to the House of Representatives in a special election in 1873 and served until 1875."
} 
their lands.

During the first election held in the Oregon Territory, on June 6, 1849, Samuel Royal Thurston became the territory's first delegate to Congress. A lawyer and newspaper editor, Thurston heard "promises of the beckoning West" in the spring of 1847 , and shortly thereafter made his way to Oregon with his wife and small son. Upon his arrival he began a successful law practice at Oregon City. ${ }^{23}$ A year later he became a member of the last provisional legislature and "made an honorable reputation as a man of ability and integrity."

Thurston left Oregon for Washington City on August 6, 1849. After six days traveling down the Columbia River "in an open boat" he reached Astoria, and departed from that point for San Francisco "in a sailing vessel." He experienced "all the dangers and discomforts incident to travel on that route in those days." Reaching his destination on November $11,1849,{ }^{25}$ Thurston found Oregon and the entire West Coast in the midst of great prosperity: the California gold rush! Thurston said at the time, , "The fame of Oregon . . . [is] now sleeping in the forgetfulness, amid the panegyrics of California, her voice ... [has been]

\footnotetext{
${ }^{23}$ Mrs. W. H. Odell, "Hon. Samuel R. Thurston," Oregon Pioneer Association Transactions of 1894, (1895), p. 70. Mrs. Odell was Elizabeth F. McClench, Thurston's widow, and according to Hubert Bancroft in his History of Oregon, (Vol. II, 1848-1888, San Francisco: The History Company, Publishers, 1888, p. 114), she fumished this biographical sketch of Thurston to him for his library. Bancroft felt the sketch was "strongly tinctured by personal and partisan feeling ... [but] valuable as a view from her standpoint of the character and services of the ambitious young man who first represented Oregon in [C]ongress." Further investigation shows Thurston's widow married W. H. Odell, who purchased the Oregon Statesman in June, 1877.

24 Thurston, p. 153.

25 Odell, p. 73.
} 
drowned in the clamour [sic] of golden reveries." Not many realized Oregon's rich possibilities then: its geography, climate or soil. Thurston took it upon himself to write articles about the Oregon Territory for newspapers throughout the United States. Thus, he spread the knowledge of the Oregon Territory throughout the country, which in turn helped to increase immigration. ${ }^{26}$

In early 1850 Governor Lane learned of President Taylor's intention to replace him; however, he had not yet received an official communication so he carried on with his duties. Although his term as governor lasted only a short time, it reflected "a period of transition from the time in which local issues predominated to that in which the Democratic Party emerged and became the controlling force in Oregon's political life."27 Lane laid the foundation for the next executive officer, yet he did not remain in office long enough for Oregonians to fully realize the limitations of their elective political power as citizens of a United States Territory. On June 18, 1850, Lane resigned as governor and headed for Yreka, California, to search for gold, leaving the office of governor to Territorial Secretary Kintzing Pritchette.

Very little is known about acting Governor Kintzing Pritchette. Born in 1806, Pritchette hailed from Philadelphia, Pennsylvania. He obtained experience as a territorial secretary in Michigan before it became a state of the Union in

26 Ibid., p. 71.

27 Kelly, p. 89. 
1837, and received his appointment as Oregon's territorial secretary from President Polk. While governor, Pritchette served as a prosecutor in the trial of the Indians responsible for the Whitman Massacre. At the end of his term as acting governor, he left Oregon and served in various federal departments until his death at Lautala in the Fiji Islands. ${ }^{28}$

After Lane's departure the citizens of the Oregon Territory realized they no longer controlled the selection of their executive officers or the justices of the territory. The democratic, home-rule-nature of Oregonians resulted in resistance toward the newly appointed Whig officials being sent by the federal government; however, Oregonians did have some measure of representation in Congress via Delegate Samuel Thurston. He was fairly successful during his short time in Washington City. One of his measures provided for a reduction in postage cost, on letters mailed from Oregon to the East Coast or other western states, such as Missouri, from twenty-five cents to three cents. Thurston's constituents in Oregon praised this measure. Another measure was the land bill, considered the "crowning act of his public life." Although there was much opposition to the bill from land speculators, members of Congress, and a foreign monopoly, Thurston "carried his measure successfully through. ..."29 According to Charles Carey, "Thurston signalized his entry into the public service by his zeal in attacking the Hudson's Bay Company and the Puget's Sound Agricultural Company, and also

${ }^{28}$ George S. Tumbull, Govemors of Oregon (Portland: Binfords \& Mort Publishers, 1959), p. 1921.

29 Odell, p. 72. 
was instrumental in framing and obtaining passage of the donation land law. . ."30

The political climate in Congress was at its "flood tide" and Thurston "saw at once [the need to] unite and combine strength from all ... ." Therefore, he sought to "shut up the book of partisan politics, and opened one in which the Whig, and the $[D]$ emocrat, the free soiler, the northern and the southern man might read together in harmony." Further, he said, "My political preferences are well understood and I am ready to defend them on all proper occasions, but I shall take good care not to obtrude them to the detriment of those measures I am seeking for Oregon." 31

Yet, Thurston was not as nonpartisan as he would have liked us to believe. A meeting between Thurston, Gaines, and the Postmaster General of the United States illustrates Thurston's partisanship. He wanted the Postmaster General to appoint a mail agent in Oregon, so he requested a Democrat but soon found "the Department would have none appointed but a Whig and that that was the inclination of Gov. Gaines."32 Morecver, Governor Gaines had the discretion in making the appointment, which frustrated Thurston. Suffice it to say, partisan politics was the norm of the era, and everyone was affected. ${ }^{33}$

\footnotetext{
${ }^{30}$ Charies H. Carey, A General History of Oregon, Volume II (Portland, Oregon: Metropolitan Press, 1936), p. 510.

31 Odell, p. 72.

32 Ibid.

33 Thurston Diary, p. 183 . In his January 29, 1850 , entry, Thurston demonstrates concern over only one party being represented among the federal appointees. He writes that this type of appointment policy could potentially "arouse party feeling" in the Oregon Territory.
} 
Shortly before Gaines's departure for New York in late December 1849, Thurston received a letter "from a gentleman who wished to go to Oregon to print some paper." The man turned out to be a Whig, and Thurston told him he had "no objections to his starting a Whig paper." He further informed the gentleman that he had no Democratic views he was afraid to discuss with him or anyone else. $^{34}$ It is noteworthy that within the next month Thurston himself conceived the idea of starting a newspaper in Oregon -- a Democratic paper!

Thurston may have conceived the idea of using a Democratic paper as a vehicle to compete with the Whig politicians in the territory. Moreover, as George S. Turnbull suggests, he may have wanted to promote himself for re-election as Oregon's delegate to Congress. ${ }^{35}$ Thurston may have felt threatened by the possibility that the popular Joseph Lane might run against him as territorial delegate. ${ }^{36}$ For whatever reasons, Thurston felt an urgency in establishing a Democratic paper in the Oregon Territory and he proceeded as rapidly as possible to do so. According to Wendell Webb, former editor of the Oregon Statesman newspaper, "Thurston and his friends in Oregon wanted a publication devoted to Jeffersonian democracy, in opposition to the territory's first newspaper, the Spectator, of [W] hig persuasion." Further, a need for a paper of

\footnotetext{
34 Ibid., p. 168. The letter is referred to in the December 21, 1849, entry.

${ }^{35}$ George S. Tumbull, History of Oregon Newspapers (Portland: Binfords \& Mort, Publishers, 1939), p. 74.

${ }^{36}$ Thurston Diary, p. 189. Upon Thurston's death, Lane became Oregon's delegate in Congress.
} 
the Democratic persuasion became urgent when they realized that soon a new Whig paper would begin publication in Portland. ${ }^{37}$ This seemed especially true since the Whigs now represented a majority of the Oregon Territory's federal officers.

Thurston was the editor of a paper in Burlington, lowa, for a short time, so he had the experience of a newspaper man, and thus would have known the proper individuals to contact in this regard. ${ }^{38}$ During mid-March of 1850 Thurston began negotiating a deal with $\mathrm{A}$. W. Stockwell and Henry Russell regarding a Democratic paper at Oregon City. ${ }^{39}$ Between April 26 and May 11, 1850, he traveled from Washington City to New York to check on a press. ${ }^{40}$ In a letter, dated May 1, 1850, Thurston speaks of sending Henry Russell to Oregon to start the Oregon Statesman. He adds, "I hope you will not fail to establish for yourselves a paper, and an organ, when the time arrives, of a well organized party." ${ }^{41}$

Further evidence of Thurston's intent to start a Democratic paper is found on the cover of his diary, where he wrote, "If I buy the office at Chicopee, I will

\footnotetext{
${ }^{37}$ Wendell Webb, The Oregon Statesman: A History (Salem, Oregon: Statesman Joumal Co., 1979), p 6.

${ }^{38}$ Diary, pp.178 and 180. The January 13,1850, entry refers to "a long talk with Mr. Fitch of Michigan" about starting a Democratic newspaper in Oregon, and the January 19, 1850, entry refers to a letter written to a "Mr. Crane of the N. Y. Evening Post relative to going to Oregon to start a paper."

${ }_{39}$ Ibid., pp. 191 and 193. March 14 and March 29, 1850, entries.

40 lbid., p. 197.

41 "Political Correspondence." Citation is from the page titled "Excer. from S. R. Thurston's Letters" It is not absolutely clear to whom this letter was written, but it is possible it was a letter to his peers in Oregon.
} 
want to buy some heading, 'Oregon Statesman,' fifty pounds ink, hundred pounds glue, roller mould, 30 bundles paper, and ten reams common writing paper, 1.50 c[en]ts per ream." ${ }^{42}$ Thurston probably wrote this list of newspaper-outfitting supplies on a visit to Chicopee, Massachusetts, his wife's home town. It was while in Chicopee he met Asahel Bush, another important figure in the origin of the Oregon Statesman and the formation of the Democratic Party in the Oregon Territory. ${ }^{43}$

Born June 4, 1824, in Westfield, Massachusetts, Asahel Bush began an apprenticeship at the Saratoga Sentinel in Saratoga Springs, New York, at age seventeen. After becoming familiar with the newspaper publishing business, young Bush went to work for the state printing office at Albany, New York, where he received an exposure to politics which, in turn, sparked an interest in law for the twenty-one-year-old man. ${ }^{44}$ Moving back to Westfield, Massachusetts, he pursued a law degree, and after much study, passed the Massachusetts bar. From January 24,1849 , through July 3,1850 , he worked both as the town law clerk and the editor of the Westfield Standard. ${ }^{45}$

42 Diary, p. 205.

43 Tumbull, Newspapers, p. 76.

${ }^{44}$ Carey, pp. $50-51$.

45 Ibid. See also, "Asahel Bush," the Moming Oregonian, December 24, 1913, p. 8; "Asahel Bush Dies; Funeral Is Today," the Moming Oregonian, December 23, 1913, p. 3; "Men Await Ghouls At Tomb of Bush," the Morming Oregonian, December 27, 1913, p. 1; "Asahel Bush As A Boss," The Sunday Oregonian, February 1, 1914, section three, p. 6; and Bob Sutton, "Asahel Bush, The Oregon Statesman," The Oregonian, Northwest section, March 7, 1971, pp. 10-11. As in the case of Gaines, there is no definitive biography on Asahel Bush. To understand his character, see Asahel Bush, "Political Correspondence, Asahel Bush II" (Portland State University Library, Portland, Oregon). This collection contains letters, sent and received by Bush, relating to Oregon 
When Thurston encountered Bush in Chicopee, Massachusetts, he found him infected with "Oregon Fever," and thus was able to engage him as the editor for his new paper. ${ }^{46}$ Bush sailed for Oregon on the steamer Empire City, departing New York for Aspinwall. He crossed the Isthmus of Panama "on a boat which was poled up the Chagres [R]iver to a point whence he proceeded on the back of a mule across the mountains." Upon reaching the Pacific side of the Isthmus, Bush boarded another sailing vessel that took him to the San Francisco harbor and the final part of his journey. Sailing up the Pacific Coast to Astoria, he arrived at Portland in September of 1850 , just a few weeks after the arrival of John Pollard Gaines. ${ }^{47}$

Before his departure for the Oregon Territory, Bush received several letters from Thurston with instructions for the Statesman. One of these letters relays Thurston's opinion regarding the Whigs and the fact the party intended to start a paper in Oregon. "It is now made certain that a Whig press is on the way for Oregon, to be established at Portland . . This then establishes the fact which I had before conjectured." Thurston continues:

temitorial and early state politics as well as the Oregon Statesman. See also Bush's editorials in the Oregon Statesman from 1851 through the early 1860s. A wealthy man at his death in 1913, Bush amassed a fortune through banking (Ladd and Bush), mills (he held interest the Salem Woolen Mills, was president and stockholder of the Salem Flouring Mills, and owner of the Salem Foundry), and other property investments in Salem, Oregon. He was also an active stockholder of the old Oregon Steam and Navigation Company, transferring his stock as the company evolved first to the Oregon Railroad and Navigation Company, then to the Oregon-Washington Railroad and Navigation Company.

${ }^{46}$ Howard McKinley Corning, ed., Dictionary of Oregon History (Portland: Binfords \& Mort, Publishers, 1956), p. 39.

47 Joseph Gaston, The Centennial History of Oregon (Chicago: S. J. Clark, 1912), p. 267. 
"You will understand my position, I have no objections to parties organizing, but while I am a Delegate, I shall not engage as a partisan, but consult soly [sic] the best interests of Oregon. It would be injudicious for me to take any other course, and I trust the Whigs will not seek to drive me to take any other position. If they attack me, and endeavor to run me dow., why we shall go before the people to try the issue, but come what may I am for Oregon . . You will not shrink at all, but will prosecute the matter with utmost vigor \& enterprise. You have . . a political war on your hands. Most of all have the good of Oregon in view, and 1st all other things, party included, be secondary. Treat your opponents with dignity \& courtesy, but with decision, ability \& firmness. ${ }^{.48}$

Thus, Thurston laid the foundation for Oregon's Democratic Party through Bush and the Oregon Statesman.

48 "Political Correspondence." Citation is dated Washington, August 11, 1850. The Whig press referred to in Thurston's letter became the Oregonian and proved to be the counterpart of the Democratic Oregon Statesman. 


\section{Chapter Four}

\section{WHIGS, DEMOCRATS, THE MEXICAN WAR, AND THE PRESIDENTIAL ELECTION OF 1848}

"Mr. Speaker, let our democratic friends be comforted with the assurance, that we are content with our position, content with our company, and content with our candidate; and that although they, in their generous sympathy, think we ought to be miserable, we really are not, and that they may dismiss the great anxiety they have on our account."

In 1846 the United States became embroiled in a conflict with Mexico over the territory known as the "Texas Republic." President James Polk, inheriting the problem of the annexed Republic of Texas from the Tyler administration, faced the probability there would soon be war with Mexico. Polk's ultimate goal was the acquisition of additional southern territory for the United States. He came close to a war with Great Britain over the Oregon Country, but fortunately negotiations brought an end to the Joint Occupancy Agreement, and the Pacific Northwest became the property of the United States.

Shortly after Texas became part of the Union, Mexico declared war against the United States. As a result the federal government called for men to volunteer their service in the war effort. Many young and ambitious politicians joined, thinking perhaps to distinguish themselves and thus attain greatness. Both Joseph Lane and John Pollard Gaines joined the ranks of men furthering their political careers through military service to their country. Largely because of his victories in the Mexican War, General Zachary Taylor, a Whig, became president of the United States in 1848, displacing Democrat James Polk.

\footnotetext{
${ }^{1}$ Roy P. Basler, ed., The Collected Works of Abraham Lincoln: Speeches and Writings 18321858 (New York: The Library of America, 1989), p. 221.
} 
The Whig and Democratic parties had been at odds with one another since the time of Andrew Jackson. Although the framers of the Constitution had hoped to avoid the factionalism of political parties, and thus wrote no role for them into the constitution, party divisions began during the administration of the first president, George Washington. Those individuals uniting behind John Adams became known as Federalists and the Democratic Party emerged from those uniting around Thomas Jefferson. The National Republicans succeeded the Federalists.

During Andrew Jackson's presidency, divisions again occurred in the nation's political parties, this time due to the president's veto of the Second National Bank's re-charter. Jackson believed the bank caused the booms and busts in the nation's economy, benefiting the wealthy while exploiting the farmers and working people. He sought to rally public opinion in support of his veto through the press. This action, on Jackson's part, was a new approach to politics, and also placed political leaders in a new role. To oppose him, the old Federalist coalition was reborn as the American Whig party. The ensuing argument between Democrats and Whigs over the bank charter became known as the "Bank War." Between 1828 and 1844, many Democratic Party members became disenchanted with the old "Jacksonism-Locofocoism" ${ }^{2}$ and turned their support toward the Whig ticket.

${ }^{2}$ Frank Otto Gatell, "Money and Party in Jacksonian America: A Quantitative Look at New York City's Men of Quality," Political Science Quarterly, LXXXII (1967), p. 244. Gatell uses the politicians of New York as his sample base. 
Party Affiliation by Time Period ${ }^{3}$

\begin{tabular}{|c|c|cc|cc|cc|}
\hline & Total No. & \multicolumn{2}{|c|}{ Identified No. } & \multicolumn{2}{|l|}{ Whig } & \multicolumn{2}{|c|}{ Democrat } \\
& & No & $\%$ & No & $\%$ & No & $\%$ \\
\hline $1828-31$ & 909 & 90 & $(9.9 \%)$ & 48 & $(53.4 \%)$ & 42 & $(46.6 \%)$ \\
\hline $1832-35$ & 909 & 379 & $(41.9 \%)$ & 291 & $(76.8 \%)$ & 88 & $(23.2 \%)$ \\
\hline $1836-39$ & 905 & 298 & $(32.9 \%)$ & 244 & $(81.9 \%)$ & 54 & $(18.8 \%)$ \\
\hline $1840-43$ & 900 & 324 & $(36.0 \%)$ & 270 & $(83.4 \%)$ & 54 & $(16.6 \%)$ \\
\hline $1844-47$ & 892 & 190 & $(21.3 \%)$ & 156 & $(82.2 \%)$ & 34 & $(17.8 \%)$ \\
\hline $1848-51$ & 880 & 134 & $(15.2 \%)$ & 106 & $(79.2 \%)$ & 28 & $(20.8 \%)$ \\
\hline
\end{tabular}

The watershed events that best explain this dramatic change in party affiliation is the Bank War and panic of 1837. Many individuals believed they were on the brink of anarchy. Success as a political organization lay in the Whigs ability to unite behind one leader and de velop an alliance with those disheartened by Democratic government control. The Whig party's birth was part of the social change that reorganized American life. Economics, religion, and ethnoculture played a role in party choice. The economic elite preferred the Whig party. Eighty-four percent of all elite Yankees were Whigs in 1844. Further, eighty-seven percent of all merchants and specialized entrepreneurs belonged to the Whig party. A majority of office holders consisted of wealthy Whigs. This is not to say there were no wealthy Democrats holding political offices. On the

${ }^{3}$ Ibid., p. 247. 
contrary, there were several who "withstood the social pressures and remained. . Democrat." ${ }^{4}$

Members of the Whig Party had a greater tendency toward moral reform than did Democrats. Many Whigs sought to Christianize America through political means. The evangelical movement became a primary vehicle to achieve their goal. It promoted new methods of capitalist exploitation, (e.g., the criticism of slavery promoted legitimized wage slavery). So, Whig party values came from the joining of Christianity with the growth and increasing need for control in the modern market society. Whigs believed every individual had the potential to be moral if the seeds to his moral character were sown properly. The Whigs were proponents of economic progress, yet they wanted it to be contained within a sphere of social and political framework. As industrialization accelerated, the population of the United States became more mobile, increasing individual opportunities. Social structures changed as new territories provided men with the chance to own property, unchaining them from the restraints of local community culture and at the same time freeing them from their bonds to the soil through modernized methods. The Whig party saw it as their task to attempt to reunite the men with their communal ties, without at the same time sacrificing modern progress. ${ }^{5}$

4 Ibid., p. 269.

5 See Daniel Walker Howe, "The Evangelical Movement and Political Culture in the North During the Second Party System," Joumal of American History, 77 (March 1, 1991). 
To the Whig mind, the annexation of Texas advanced the anti-republican doctrines promoted by their political opponents, the Democrats. Instead they proposed the alternative path of controlled expansion so private enterprise could be combined with public interest. The party espoused the idea that "progress and change should not degenerate in to wild and fistful restlessness ... . [They should] be harmonized, directed and concentrated into healthful, beneficial movement." 6

The American Whig party "believed that the primary object of all political institutions ought to be to consult the greatest good to the greatest number."7 Whigs argued that the United States shouldn't expand land acquisitions until all its citizens were protected in life, liberty, and property. The Whigs opposed the annexation of Texas because the territory would provide the opportunity for the expansion of the institution of slavery. They accused their opposition of having a "hunger for power and an unquenchable thirst for territorial aggrandizement."8 Further, they became increasingly alarmed concerning "annexation's effect on the stability of the Union."

The Whigs opposed the Democratic administration's policies during the Mexican War and they intended to use its events to their advantage. The political dissension and evolution in the no-territory arguments helps to explain "the

\footnotetext{
${ }^{6}$ Michael A. Momison, "Westward the Curse of Empire: Texas Annexation and the American Whig Party, "Joumal of the Early Republic, 10 (Summer 1990), 231.

7 Ibid., 232.

8 Ibid., 234.

9 Ibid., 235.
} 
nature of the political culture that provided the context for . . . opposition."10

Whig's promoted individual and national independence; Democrats promoted the dependence of one class upon another. Whigs believed the pursuit of individual liberty and national prosperity depended upon an active government representative of its citizen's interests. Democratic ideals found a basis in a "nation covetous of land [and] greedy for the acquisition of territory."11 Because of their commitment to a "program of controlled, peaceful expansion," Whigs became uncomfortable with the manner in which Polk acquired California and the Southwestern borderlands. ${ }^{12}$

In a letter written to William $\mathrm{H}$. Herndon in February of 1848 , Abraham Lincoln, then a representative in Congress, declared the Whig Party's sentiment toward the Democrat Party's instigation cf the Mexican War:

". . . the war was unnecessarily and unconstitutionally commenced by the President . . . nearly all the [Whigs] voted against the preamble declaring that war existed by the act of Mexico .... As to the [W] hig men who have participated in the war, so far as they have spoken to my hearing, they do not hesitate to denounce, as unjust, the Presidents [sic] conduct in the beginning of the war. . . There are two such [W] higs on this floor, Col. Haskell and Major Gaines" ${ }^{13}$

\footnotetext{
${ }^{10}$ Michael A. Momison, "New Territory Versus No Temitory: The Whig Party and the Politics of Westem Expansion, 1846-1849," The Westem Historical Quarterly, 23 (February 1, 1992), p. 27. 11 Ibid., p. 32.

12 Ibid., p. 28. For further discussion of the formation of the Whig Party and partisan politics see Thomas Brown, Politics and Statesmanship: Essays on the American Whig Party (New York: Columbia Press, 1985); Malcolm E. Carroll, Origins of the Whig Party (Durnam: Duke University Press, 1925); Ronald P. Formisano, The Birth of Mass Political Parties: Michigan, 1827-1861 (Princeton: Princeton University Press, 1971) and; Michael Fitzgibbon Holt, Political Parties and American Political Development: From the Age of Jackson to the Age of Lincoln (Baton Rouge: Louisiana State University Press, 1992).

${ }_{13}$ Basler, pp. 172-173.
} 
In another letter written by Lincoln to Usher F. Linder in March the same year, Lincoln repeats his stand against the Mexican War, condemning President Polk's conduct in the process. Moreover, he demonstrates Whig Party support for Zachary Taylor as their Presidential candidate for the election of 1848.

". . . There are in this H[ouse of] R[epresentatives] some more than forty members who support Genl. [sic] Taylor for the Presidency, every one of whom has voted that the war was unnecessarily and unconstitutionally commenced by the President . . . 'More than this; two of these, Col. Haskell and Major Gaines, themselves fought in Mexico; and yet they vote and speak just as the rest of us do, without ever dreaming that they 'strip' themselves of any laurels. . ."

On July 27,1848 , Lincoln addressed the House of Representatives with a speech entitled "The Whigs and the War," in which he continued his stand against the war and his support of General Taylor for president:

". . . But as Gen: [sic] Taylor is, par excellence, the hero of the Mexican war; and, as you [D]emocrats say we [W]higs have always opposed the war, you think it must be very awkward and embarrassing for us to go for Gen: [sic] Taylor. The declaration that we have always opposed the war, is true or false, accordingly as one may understand the term 'opposing the war.' If to say 'the war was unnecessarily and unconstitutionally commenced by the President' be opposing the war, then the [W] higs have very generally opposed it . . . [M] arching an army into the midst of a peaceful Mexican settlement, frightening the inhabitants away, leaving their growing crops, and other property to destruction, to you may appear a perfectly amiable, peaceful, unprovoking procedure; but it does not appear so to us. . But if, when the war had begun, and had become the cause of the country, the giving of our money and our blood, in common with yours, was support of the war, then it is not true that we have always opposed the war . . I think of all those brave ... Americans ... Many of them, [W]higs and [D]emocrats . . my constituents and personal friends . . Col: Haskell, and Major Gaines, members here, both fought in the war; and one of them underwent extraordinary perils and hardships; still they, like all other [W] higs here, vote, on the record, that the war was unnecessarily and unconstitutionally commenced by the President." ${ }^{15}$

14 Ibid., pp. 178-180.
15 Ibid., pp. 219-221. 
The inauguration of Zachary Taylor as President of the United States, in March 1849, resulted in a change of political parties at the federal level. A change in political parties at the federal level generally meant a change in territorial governments as well. During his presidential candidacy Taylor's platform included a statement in which he declared "that no removals would be made except for cause."16 After Taylor's inauguration, a great number of men received notice of their replacement, including Joseph Lane of the Oregon Territory. Political difficulties in Oregon began with Lane's removal. His friends and fellow Democrats "resented the implied charge against his efficiency."17 The issue presented itself in Congress, where the Democrats alluded to Lane's dismissal as a result of partisan politics. The Whigs, meanwhile, declared Lane's removal due to just cause, and the "result of an investigation of . . Lane and one other. . ."18

The investigation suggested the failure, on Lane's part, to send quickly the report on Indian affairs in the Oregon Territory to the Taylor Administration. Lane's report may have been delayed by a lack of consistent mail service to and from the Territory. Lane also may have been waiting for instructions from the federal government regarding the Indians. The investigation also cited several complaints about Lane made by individuals from the Territory and elsewhere.

\footnotetext{
Harriet Lane, p. 16.

Ibid.

Ibid., The other individual was Colonel Weller of the Boundary Commission.
} 
According to Lane's granddaughter, Harriet Lane, at least a few of the complaints came from "anonymous letters . . . in the New York Tribune, written by Mr. [J. Q.] Thornton, ex-Indian agent, reflecting upon the private character of Lane. . . ."19 The relationship between Joseph Lane and Zachary Taylor further complicates the political scenario. Both men served together in the Mexican War, Taylor being Lane's commanding officer. Several incidents arose out of the Battle of Buena Vista, causing long term friction between the two soldiers. Although Lane "fought acceptably at Buena Vista, displaying exemplary courage under fire and taking a ball through one shoulder ... two days before that battle he got into a fist fight with one of his own colonels. .."20 After being separated from the colonel, Lane went to his tent to get his rifle. It took several men to prevent him from using his rifle to kill the colonel. As a result of this episode Taylor removed Lane from direct command of the Third Indiana Regiment. ${ }^{21}$

19 Ibid., p. 17; Coming, p. 243-244. Bom on August 24, 1810, at Mt. Pleasant, Virginia, Jesse Quinn Thomton became a govemment leader in early Oregon. A lawyer by trade, Thomton passed the Virginia bar and came, with his wife, Nancy Logan Thomton, overland to Oregon in 1846. They amived in the Willamette valley via the Scott-Applegate Trail. He tells of his early life and experience on the Oregon Trail in a two-volume book titled Oregon and Califomia in 1848. He became judge of the Provisional Supreme Court in 1847, then resigned to go to Washington City and assist in the creation of the Oregon Temitory. Thomton practiced law at Oregon City, Albany, Portland, and Salem. He passed away on Februâry 5, 1888.

20 Clark, p. 225.

21 Ibid., p. 224-225. Clark refers to the colonel as "the irascible and erratic James H. Lane." It is unclear whether he is a relative of Joseph Lane; however James Lane commanded the Third Indiana, which explains Joseph Lane's removal in the chain of command above James Lane. Lane's character during the war is further illustrated after his victory at Huamantla, when he 'tumed his troops loose on the town because his cavalry commander, Major Sam Walker, had allegedly been killed by a civilian sniper duning a Mexican counterattack." According to Clark, "the sack of Huamantla -- an awesome orgy of rape, murder, desecration and drunkenness -- was the ultimate atrocity of a war made hideous by atrocities." 
Also during the Battle of Buena Vista, Lane ordered his men, the artillery section of the Second Indianans, to advance. At the same time another officer, a Colonel Bowles, ${ }^{22}$ thinking the artillery had retreated, ordered his men to cease fire without gaining the authority to do so from Lane. Of course the men later rallied and fought hard; however, when Lane made his report he did not know the men had been ordered to cease fire and fall back -- nor did Taylor when he made his report to the Secretary of War. In other words, the report more or less referred to the Indianans as failing to act on the order of an officer -- a serious mark on the men's character.

Upon learning of Bowles's error, Lane asked Taylor to revise his report to the Secretary of War. When Taylor refused to revise the report Lane pursued vindication for the men under his command by taking "the stump in Indiana as a political demagogue in the Presidential canvass ... denounc[ing] General Taylor, for his report, as a slanderer and a liar . .." ${ }^{23}$ This caused a lasting rift between Taylor and Lane. Colonel Bowles requested a court of inquiry "to investigate his conduct in the Battle of the 23rd of February, 1847, between the forces of General Taylor and General Santa Ana [sic] in Mexico." The results of the inquiry showed the Indianans "did not yield their ground until ordered to do so by the colonel of the regiment." Briefly absent from duty, due to illness, Bowles didn't know the artillery had not retreated. Further, Bowles never received a

\footnotetext{
22 I have been unable to discover this officer's first name.

${ }^{23}$ The Covington Joumal, August 24, 1849, p.2.
} 
communication containing the battle plan from Lane. Moreover the investigation found "Colonel Bowles evinced no want of personal courage or bravery but that he did manifest a want of capacity and judgment as a commander."24

Lane went on to achieve military glory later in the war, when he received command of "a few hundred well-mounted men and order[s] to pacify the country." ${ }^{25}$ In a series of skirmishes Lane's "hard-riding, hard-fighting troopers cleaned out almost every major pocket of resistance, ${ }^{, 26}$ earning him the rank of brevet major general. The Democratic press back home, looking for a hero to justify the war with Mexico, compared Lane to the "celebrated Swamp Fox of the Revolution," and dubbed him "Marion of the Mexican War."27 Thus, Lane returned home to Indiana a hero with a nationwide reputation, which in turn led to his appointment as Oregon's first territorial governor.

As mentioned above, Lane's removal as territorial governor caused serious political partisanism in the Oregon Territory. The people of the territory "came to attach a good deal of significance to party, becoming ardent supporters of whichever side they were in sympathy with, the most part of the people being Democrats." ${ }^{28}$ So, whoever became the governor of the Oregon Territory would face a political challenge upon arrival. Thus, when President Taylor appointed John Pollard Gaines, fellow Whig, as Oregon's territorial governor, Gaines

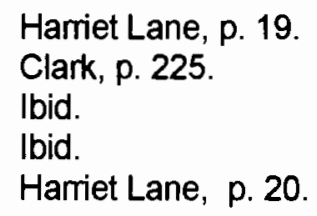


encountered an uphill battle -- even before he departed from Kentucky. Once Gaines accepted the assignment, Taylor appointed the other territorial officers, including Edward Hamilton as secretary of the territory, and William Strong as territorial supreme court justice. It was now late in the year 1849 , and the citizens of the Oregon Territory awaited the arrival of their new officials. 


\section{Chapter Five}

\section{AROUND THE HORN TO OREGON}

"On or about the 18th Nov [sic] we left our dearly beloved Native State for the City of N. Y. at which place the ship on which [we] expected [to] take passage was to take her departure-- Having first touched at Washington City we arrived at that place about the 10th Dec- and ascertained to our regret that the ship would not leave so soon as was expected. ... On the 3d Jan [sic] 1850 all things being in readiness, we weighed anchor and took our departure from the bussy [sic] and bustle of the city for the far west--"'1

Upon accepting his appointment as Oregon's territorial governor, Gaines sold the family farm in Boone County, Kentucky. Together with his family he bid farewell to his son Richard, brother Archibald, and numerous friends, many of whom "loathed to part with him on account of the valuable services he had rendered the state politically." Gaines's brother, Archibald, purchased the farm and other property for $\$ 14,000$, "a portion of which was in hand the remainder on credit of 2 years." ${ }^{2}$ The remaining members of the family, including Gaines's wife, Elizabeth; his sons, twenty-six-year-old Archibald and fourteen-year-old Abner; and his daughters, twenty-three-year-old Ann Maria, twenty-year-old Florelle, seventeen-year-old Harriett, ten-year-old Mary Elizabeth, and eightyear-old Matilda, departed for New York City on November 18, 1849.

On the way to New York the family stopped at Washington City where Gaines received information and instructions from Samuel Thurston and President Taylor. After a brief stopover in Baltimore, Maryland, the family arrived

\footnotetext{
Archibald K. Gaines Joumal.

Ibid.
} 
in New York City on December 10,1849, expecting their ship to be ready for passage around Cape Horn to Oregon. Fortunately it was not ready. Archibald Gaines wrote in his journal, "Preparations for a voyage of this kind being much more extensive, and requiring more time than was anticipated, we were ultimately satisfied with the delay." ${ }^{3}$ The family stayed nearly four weeks at the Howard Hotel, at a cost of $\$ 213.83$ for room and board. ${ }^{4}$ Among other things, the delay allowed time for Governor Gaines to purchase and load on the ship books for Oregon's territorial library.

Captain C. W. Kennedy wrote a note to Gaines on New Year's Day, 1850, that said, "Will you be kind enough to inform me when it will be eminent for yourself and the rest of the passengers to repair on board." Gaines replied that he and his party would board the next day before noon. ${ }^{5}$ On January 3,1850 , the party finally departed New York City aboard the United States ship Supply. Besides his immediate family, Gaines's party included Territorial Secretary Edward Hamilton and Territorial Supreme Court Judge William Strong, together with their families.

On the fifth day at sea the party experienced a violent storm that lasted twenty-two hours. Hearing the pounding wind and waves reminded Archibald of

\footnotetext{
${ }^{3}$ Ibid.

4 Gaines Papers, reel 4, box 7, folder 2, frame 00087

5 Gaines Papers, reel 2, box 4, folder 2, Frame 00456. Letter to Govemor J. P. Gaines from C. W. Kennedy, U. S. Ship Supply, Navy Yard, New York, January 1, 1850.
} 
the family's story about General Andrew Jackson and the roaring cannons during the January 1815 battle of New Orleans:

"My mind as I contemplated the danger in which we were placed would occasionally dwell upon that day so celebrated with U. S. All were pleased at the announcement about 11 oclock [sic] P.M. that the gale had broken, or as we termed it that the hostilities had ceased, but little disposition was indicated on the part of any for a second engagement. "6

Everyone experienced sea sickness during the storm except for Gaines and his eldest daughter, Harriett. The family's cabin filled with several feet of water from leaking tanks, and their amenities were few. The officers extended to the family the use of "a portion of their apartments which were readily accepted." Archibald stayed during the night with his sister, Florelle, who had the worst case of sea sickness. Matilda joined him, and they both slept on the floor beside the berth where Florelle lay. ${ }^{7}$

The weather remained rough until the ship passed the Gulf Stream. On February 7, 1850, after crossing the Equator in longitude 35 west from Greenwich, "Father Neptune" visited the party and "the usual ceremonies were passed through, as are usual on occasions of that kind." ${ }^{8}$ Three days later they sighted land near Pernambuco and on February 22, 1850, fifty days since their departure from New York City the party finally sighted the "beautiful City of Rio."”

\footnotetext{
6 Archibald K. Gaines Joumal.

7 Ibid.

${ }^{8}$ Ibid. Father Neptune's visit refers to the ceremony of shaving which involved sailors passing the over the Equator for the first time. It remains a tradition today.

${ }^{9}$ Ibid.
} 
For twenty-four hours the Supply waited to enter the harbor. Spotting Cape Frio on February 21, Archibald thought it "the most beautiful shaped land. . ever beheld . . . [and] the delights of our party at a sight of the best of all friends, land, sweet land, together with a prospect of a short respite from the confinement to which we had been subjected for 50 days, can better be imagined than described." ${ }^{10}$ Because of the tides the ship was not able to weigh anchor until February 23. As they entered the harbor a symphony of music greeted them, flowing from ships of war and commerce of all nations. The American ships issued Hail Columbia which made the Gaines family feel welcomed. They met with the ship of war, Ohio, hailing from San Francisco; but having been at sea for five months, she carried no recent news. ${ }^{11}$

At that time of year Rio was in full bloom. Archibald wrote,

"To find the grass green and the trees in bloom, after coming from the snows of $\mathrm{N}$ [orth] A[merica] was to one unaccustomed a most beautiful sight. Rio is surrounded on all sides except at the entrance of the Harbour by the most beautiful shaped mountains that I ever saw . . . [It] is beautifully interspersed with small elevations of land [and] with the natural growth of the country."12

The Portuguese "aristocracy" lived in "respectable style" yet the rest of the city was in the state of decay. According to Archibald the city had a two-thirds black population that was "... made to answer the purposes of beasts, for ... transportation." ${ }^{13}$ The sound of human retching obscured the beauty of the

\footnotetext{
${ }^{10}$ lbid.

11 Ibid.

${ }^{12}$ Ibid.

13 Ibid.
} 
country, and testified to the presence of the yellow fever. Indeed, the yellow fever caused much anxiety for all who entered the harbor at Rio, including the Gaines party. $^{14}$

Concerned for his family's safety, Governor Gaines sought a "healthy" residence for the duration of their stay at Rio. Archibald writes, "Father took up . . residence in a very beautiful and healthy part of the city ..." near Batafogo ". . . at which our family enjoyed themselves very much indeed." Both the minister and governor of Rio showed much interest in the family's "fate and comfort." They attended a fine party, given in their honor by Rio's governor, and according to Archibald, "my sisters enjoyed themselves very much indeed. .." The Gaines family seemed safe from the ravages of the fever.

While the party enjoyed their holiday on land, the ship's crew experienced the death of one of its members from the yellow fever. The crew member, a lieutenant, was on his way home after a tinree year absence when his death occurred. The lieutenant's death threw "a damper over the spirits of the officers of our ship," said Archibald in his journal. ${ }^{15}$

On March 4, 1850, Captain Kennedy, the Supply's commander, ordered the ship's departure from Rio. He planned to finish outfitting the Supply at Santa Catharina. ${ }^{16}$ After sailing south a distance of 400 miles from the City of Rio, the

\footnotetext{
14 Ibid.

15 Ibid.

${ }^{16}$ Ibid.
} 
party arrived at the Island of Santa Catharina on March 7. The harbor of Santa Catharina Island stands about twelve miles from the town of the same name, and conveyance to shore took place on small ships. Captain R. S. Cathcart was the vice consul of the island. Upon their arrival, Gaines and his daughters, Florelle, Harriett, and Mary Elizabeth visited Cathcart, who was also an old Nantucket whaler. John Gaines wrote in his journal that their day with the vice consul was "spent . . very agreeably ... [we] were very hospitably entertained by him." ${ }^{17}$

During the three day voyage to Santa Catharina there had been "but little sickness on board, except a few cases amongst the sailors." The captain himself had become ill from the yellow fever a day or two before their arrival at Santa Catharina. Then the disease afflicted a member of the Gaines party. Archibald wrote, "Judge Strong's son, Frederick, age six, succumbed to the disease" and "was buried at sea on the trip from Rio to the Island."18 The party remained confident, however, that the disease would not harm its remaining members.

The family normally dined together on board the ship. On March 12 , Harriett arrived at dinner, leaning upon her father for support. This caused great concern amongst the family who feared "something serious affected her."19 Harriett was usually a very animated and social creature, but on this day she appeared subdued, and refused to eat. Even though the ship's physician was very attentive, her condition grew worse. On March 17 she suddenly became

17 Gaines Papers, reel 3, box 6, folder 1, frame 00425 .

18 Archibald K. Gaines Joumal. 
animated, and appeared her usual self. Archibald says, "She showed a disposition to talk [and] exhibit her wit for which she was so much celebrated. . "20 His and other family members' hopes were dashed, however, when her condition again deteriorated. Then she told the family she would not recover from her illness. Archibald describes the family's grief at Harriett's passing:

"On Monday about 4 oclock [sic] of the 18th [March] it became evident that our Harriett, the pride of the family, the life of the ship, she who had ministered to the wants and comforts of all ... who had kept us in spirits by her lively disposition and sparkling wit in times of trouble and danger, who had braved the danger of the celebrated 8th [January] without an emotion -- who was the polar star toward whom all looked for consolation in trouble, around whom all centered when there was to be an exhibition of her wit or musical powers, who had left a name indelible at every point at which we had stopped between the City of Rio and the place of her death, our universally popular and beloved Harriett, the magnet around whom all centered, could not live .. How mysterious the ways of Providence, our beloved sister who had so much to live for, everything to gain and nothing to loose, who was destined to be an ornament to the family, and to society - whose every act was purity, resulting from the best motives, why she should be taken from us is indeed a mystery, thou hast doubtless another [sic] and better field for her, thou wilt always extend around her thy kind protecting arm. May she live with thee as she did with us in ease, in happiness, in contentment, in spirits." ${ }^{\prime 1}$

Harriett was "handsomely prepared for the grave by Mrs. [Edward] Hamilton and [Mrs. William] Strong ... ." and buried on the mainland of Brazil near the home of Captain Cathcart. ${ }^{22}$ Cathcart and the ship's officers escorted the funeral party from the ship to the burial spot on March 20. Two days before Harriett's death, twenty-year-old Florelle became ill with the same symptoms

\footnotetext{
19 Ibid.

20 lbid.

21 Ibid.

22 Ibid.
} 
shown by her younger sister. At the time of Harriett's death Florelle could barely sit up. Soon it became evident to the family that Florelle would not survive. According to Archibald, she "expressed a wish to follow Harriett - had no desire to live - she for whom she lived and in whom all her thoughts were centered was taken from her- Her sufferings mentally were intense, she was inconsolable . .."23 On the day of Harriett's funeral, Gaines decided to take his wife and remaining children onto Santa Catharina Island "for the purposes of getting into a better atmosphere and to get away from the place of the late scenes ..." He thought that, perhaps, Florelle's condition might improve in a better atmosphere. ${ }^{24}$

Several "respectable" boarding houses on the island had previously solicited Gaines's patronage. Territorial Secretary Hamilton obtained a house a few days before Gaines decided to bring his family ashore. Much to the chagrin of the family, the inhabitants of the island were very disturbed at the prospect of renting to those with the yellow fever amongst them. Fortunately, they located a small house "on a high eminence overlooking the bay." ${ }^{25}$ Besides renting the house to the family, the owner also offered to provide them with food. The family found the house pleasant enough; a cool breeze provided comfort from the extremely warm weather.

\footnotetext{
${ }^{23}$ Ibid.

24 Ibid.

${ }^{25}$ Ibid.
} 
Florelle showed a fatal sign of the yellow fever, the dreaded black vomit, at about ten in the evening on March 20. Her condition continued to worsen through the night, and on the next morning Gaines requested a French physician to come attend to her. An interpreter hac to be found, for the doctor did not speak English. Consequently, the family became frustrated because they could not determine his diagnosis of Florelle's condition. The doctor gave a prescription, but it had little, if any effect, and she continued to grow worse. She became delirious that evening and the next morning "all hope vanished." ${ }^{26}$ The doctor made a final effort to save her life, but to no avail. Again, Archibald describes the family's grief:

"[S]he who was so celebrated for sound judgment and discretion, who had exercised a[s] guardian [over] our Harriett, who had always taken interest in and protected her at all times- must be parted with . . I was dispatched to the ship in a canoe for medicine. I had but little expectation of finding her alive on return, it was but too true, I returned about 12 oclock [sic] her spirit had taken its flight to a better world about one hour previous, $22^{d}$ March 1850[.] She was buried by the side of her sister Harriett, at which place she was always found when they were living, with the same ceremonies, read by the same person . . . I always felt confident of Harriett's safety when [Florelle] was with her. [Florelle] being older was more discrete and gentle- The deep interest she took in [Harriett] was truly astonishing- She led her in the paths of rectitude, her advice was good and effective and kindly rec[eive]d. I feel now that [Florelle] has followed [Harriett] to the grave, that she will lead her to that house not made with hands, Eternal in the heavens- She had great reverence for religion, and religious subjects- and was a true believer in Christianity." ${ }^{27}$

Florelle's funeral occurred on March 23, 1850.

26 Ibid.

${ }^{27}$ Ibid. 
There was a bit of controversy over the burial of these two young women on the foreign soil of Brazil. Archibald thought it was because his sisters were both foreigners and Protestants. Apparently Captain Cathcart told the president of the island that he was the owner of the property in question, and therefore he would "exercise his own judgment" as to whether the burial would take place. Further, Cathcart was an American, attending to American business and interests, and there seemed to be no question as to the protection of American citizens by the United States government "no matter how much the Brazilian [government] should take exceptions." Additionally, Cathcart conveyed to the president that it was

". . . his duty to the utmost of the means in his power, by nature of his office to minister to the wants, comforts and necessities of his countrymen, even by coffering upon them the benefit of his own property of which he had a clear and indisputable right to the extent of his claim, both by the laws of nature and nations, that by failing to do so, he would prove recreant to his duty, and forfeit all protection to the American flag- that notwithstanding at first sight it might appear to be in violation of the principles of their religion, that it could not apply to the [privileges and] rights of an officer of a foreign gov[ernment] that it would at once destroy the purposes for which he held his station."28

The yellow fever struck a third time. When Ann Maria began suffering from the black vomit Gaines "considered her lost." He even left the island. The possibility of losing yet another child was too much for him bear. Imagine his joy upon learning of her survival!

28 Ibid. 
On March 28, 1850, the Supply weighed anchor and sailed out of the harbor of Santa Catharina Island. Reflecting upon the sickness experienced by all aboard the Supply at Rio and Santa Catharina, Archibald criticized the ship's captain for not leaving sooner:

"There was much sickness on the ship amongst officers [and] men after our arrival in the Harbour . . . I thought the ship seemed to be placed in an unhealthy place ... There is a question in my mind as to the necessity or policy of touching at this point, we had been in Rio for 10 days which was ample time to have made all the preparations necessary to a passage to Valparaiso, the weather was excessively warm and oppressive, but little air stirring compared to that while at sea- there is always at sea a fine fresh, healthy breeze in motion, which would have been highly beneficial under the circumstances, every step was taking us into a colder, and healthy region the more remote from the unhealthy region in which we were placed, in the same proportion would its influence assist- in one week after leaving Santa Catharina we were in a pleasant healthy region . . . I am not willing to admit, that, we could not have made the passage, with the preparations made at Rio, I believe that we could have done so, but at the same time I am compelled to say that cowardice, and incompetency to discharge duties in an emergency was the cause of our not sailing . . . -- it was a base retreat into a Hog puddle -- it was a retreat to a short distance into a supposed hiding place . . . I expressed myself before leaving Rio that I hoped that if the Capt[ain] was not in entire readiness to leave for the Cape, that he would remain 24 or 48 hours and make himself so - our crew at that time were in health with the exception or one or two ... the passangers [sic] were all in perfect health except a son of Judge Strong who died on the trip here- our ship might be said to be healthy, at the time we left that post. Had we therefore gone entirely out of the latitudes, with cold weather, away from under the influence of disease- instead of stopping for 21 days at a place which had the appearance at first sight of being more unhealthy than the one we had left- much suffering and some deaths might have been avoided." 29

Further, he believed both the captain and the ship's physician, should be held responsible for the deaths:

\footnotetext{
${ }^{29}$ Ibid. It is true that Harriett and Florelle might have survived if the ship had continued around the Hom from Rio instead of stopping in Santa Catharina. Further, the yellow fever spreads by mosquito bites and mosquitoes will not survive the salty sea atmosphere or a cold climate.
} 
"The question presents itself as to whom the responsibility of this unwise . . step should be thrown upon-- I have formed but a poor opinion of Capt[ain] Kennedy as a commander ... He is a man that is extremely fond of having it understood that he is an officer in the U.S. Navy, and that he is the commander of this ship, this fact he has more than once published for our information . . I look upon him as a bad sailor on account of his timidity, and his extreme caution which may possibly proceed from his ambition as an officer as his reputation may depend upon the success of his voyages ... He is not the man to make a quick passage$\mathrm{He}$ is not the man to pass quick under full sail, over dangerous places. He is not the man for a bold and successful attack - He has often stript [sic] the ship when under full sail for the most trifling causes -- frequently, much to the merriment of his subordinates - thereby much retarding the progress of the ship . . I stated, that I supposed the Capt[ain] had power in his hands of stopping or not as he chose. Yet he may have felt himself under some obligations to respect the advice of the gentleman who had been placed on the ship as physician. This gentleman attended my sister Harriett in her illness, his course was not altogether approved by me -- He is greatly deficient in judgment and common sense, and in practice, and in courage and in good temper, all the requisites so very necessary for the station he fills ..."130

So, after spending two weeks in a foreign country, and experiencing much grief over the loss of loved ones, the Gaines party continued on their journey around Cape Horn. The Supply experienced a strong northwest wind on April 10,1850 , enabling it to sail around the Horn, passing latitude fifty-six degrees. It suddenly encountered a strong headwind that blew it south to eighty degrees latitude before the crew regained control. Forty-nine days after the party left Santa Catharina they arrived at Valparaiso after passing around Cape Horn. Judge Strong, another victim of the yellow fever, was regaining his health -growing stronger every day.

30 Ibid. 
Gaines received a letter from J. R. Underwood, at some point between

Santa Catharina and Valparaiso, informing him about the progress of the

Committee on Territories regarding his numination as governor of the Oregon

Territory. The letter read,

"You may think it strange but it is nevertheless true that the committee on territories has not yet acted upon your nomination, much less reported it to the Senate. . . I I am apprehensive that your nomination will meet with opposition. . . . When I proposed to take it up the Chairman, Douglas, said that the Senators from Indiana wished to appear before the Committee in regard to the nomination. We requested him to fix a day $\&$ invite them to attend. This he failed to do or at least they never attended. . . So far as I can understand the nature of the opposition there is nothing in it of a personal character towards you ... it grows out of hostility toward Gen[eral] Taylor in consequence of the removal of Lane \& the Indianans are somewhat disposed to gratify their malignity to him by vengeance upon you. I trust however that you will pass thro (sic) unharmed. I shall certainly give you the earliest information as to the result. I send this to Panama where it will arrive before you no doubt $\&$ from which place I hope you will address me a line. ..."31

He did not know it at the time, but this letter was an omen of things to come.

The Gaines party arrived at the port of Valparaiso on May 16, 1850.

According to Archibald, Valparaiso had a better climate, stronger enterprise, and

a larger population than Rio. Archibald describes the local native population as a "worthless looking people who resembled the Indians of N[orth] A[merica] and are the descendants of original inhabitant[s] of this country." They lived in "miserable huts" in a country where the Spanish government held all the wealth. ${ }^{32}$ The prospect of eating an abundance of the "finest fruits known in the world . . .

31 Gaines Papers, reel 2, box 4, folder 2, frame 00461-00462. Letter to Govemor J. P. Gaines from J. R. Underwood, Washington City, March 13, 1850.

${ }^{32}$ Archibald K. Gaines Joumal. 
delicious grape[s], pears, peaches, quinces, oranges . . water melons [sic] . ..," delighted the Gaines family. ${ }^{33}$ The family spent their time at Valparaiso relaxing in a very cozy residence, visited often by Americans. There they met Bailey Peyton, the American minister to China. They also met the consul of Valparaiso, who was from Baltimore, and had been appointed by President Taylor. The merchants of the city were engaged in a profitable enterprise stemming from the rush of emigration to the California gold fields. Many American ships were in the harbor, most bound for California laden with emigrants and produce. ${ }^{34}$

After the short respite, the Supply left Valparaiso around noon, May 25, 1850. The winds and the weather were fair until crossing the equator. Late in the evening of June 14 , at about twelve degrees north of the equator the ship met with bad winds blowing from the north that sent it sailing west. The winds brought cooler weather and more delay. Crossing the equator at longitude 108 degrees west, the wind blew the ship to longitude 132 degrees west. The wind still blew the wrong direction on July 3,1850 . In his journal entry of the same day, Archibald relates the party's concern about the delay:

"[We are] growing more anxious every day to reach our place of destination, our progress is slow, having been out from port 39 days . . . It is 6 months to day [sic] since we saill[ed] from our native land -- expected when we left to have made the trip in 4 months -- we are yet within a month or more of our place of destination." ${ }^{35}$

\footnotetext{
${ }^{33}$ Ibid.

34 Ibid. The gold rush in California resulted in profitable enterprise for many who chose to capitalize upon the situation.

35 Ibid.
} 
The Gaines family was homesick. Archibald writes of "old Kentucky," friends and family and their preparations for the Fourth of July:

"In old Kentucky at this time I know our friends are all making active preparations for to morrow [sic] the glorious $4^{\text {th }}$. How my mind dwells upon it. Here I am cooped on the ship, worn out with the fatigue and monotony of this life- How I pant for a roam in the country once more -- How delighted I would be to sit under the beautiful maple, in our front yard, on our farm in Boone, with my friends with whom I was raised, around me -- How much I should delight to spend the 4th in this way -- this pleasure I shall forego for a long time to come -- I shall however, still look for[ward] to that day." ${ }^{36}$

On Independence Day the ship's location was latitude twenty-four degrees, thirty feet and longitude 133 degrees, thirty-three feet. The party spent the day reflecting on the signers of the Declaration of Independence and "the causes which led up to it ..." The ladies of the party "gave quite a respectable dinner to the officers of the ship [during] which toasts were drank ... the day well spent."37

By July 10,1850 , the Supply had traveled nearly 18,000 miles. It continued on its northwesterly course, heading toward San Francisco, and fighting the northern wind. Due to the delay caused by the wind, firewood began to run short, and the captain issued an order on "the necessity of being economical. ${ }^{38}$ On July 11 the wind finally began to blow in the right direction. The party felt "some consolation, after . . traveling for 10 [d]ays in an almost

\footnotetext{
36 Ibid.

37 Ibid.

38 Ibid.
} 
opposition direction from S[an] Francisco ... we are to day [sic] in latitude $57^{\circ}$, $51^{\prime}$ Longitude $141^{\circ}, 24^{\prime}$ west -- 950 miles from S[an] Francisco. ... ."39

During the night of July 18 , the crew anchored the Supply just outside the San Francisco Harbor because they feared hitting the sand bar. Gaines and his party looked forward to seeing San Francisco and the next afternoon at four they entered the harbor. The ship anchored at Sausalito, about eight miles south of the City and "all [were] . . . on tiptoe to see the most remarkable of American Cities." ${ }^{\prime 40}$ The Supply was amongst 700 other ships lying at anchor in the harbor. Ship owners were experiencing great difficulty in persuading men to unload freight because of the "great temptation at the mines." Money flowed freely and the gambling was rampant. After having read glowing descriptions of the city, the atmosphere displeased the party. The wind was blowing and it was "as cold as that of December in the State of Kentucky . .."42 Surrounded by "high hills," Archibald writes, San Francisco was a city where "all classes and conditions of people are to be found . . all countries being fully represented." ${ }^{43}$

As a result of the gold rush, the party experienced "much difficulty in getting suitable conveyance ..." to Astoria on the coast of the Oregon Territory. ${ }^{44}$ After arriving in the San Francisco Harbor, Gaines wrote a letter, on July 19,

\footnotetext{
39 Ibid.

40 Ibid.

41 lbid

42 Ibid

${ }^{43}$ Ibid.

44 Ibid.
} 
1850, to Commodore Thomas Jones, commander in the U. S. Navy, of a squadron stationed in the Pacific Ocean. Gaines enclosed with his letter an order he had obtained, while in Washington City the previous December, from Secretary of the Navy, William Ballard Preston:

"Upon the arrival at San Francisco, of the U.S. Store Ship Supply you will be pleased to furnish to the Hon. John P. Gaines, Governor of Oregon, and his party, (who have taken passage on that ship for the Pacific) transportation by means of one of the vessels under your command to enable them to reach their destination as early as practicable."

Gaines appealed to the commodore for a speedy passage to Oregon:

"Our freight, from five to eight tons, the great length of [time we] have been at sea, together with great family afflictions, impels me [to ask the] favor of you to forward us to our destination at the earliest possible [time] compatible with the public convenience. Should there be no public [vessel] at hand, we should prefer that the Supply should be ordered to [continue] the voyage to Oregon, and whatever vessel may be sent may be placed under our direction in relation to our place of landing." ${ }^{46}$

Apparently, due to the urgency of Gaines's letter, the Navy forwarded the letter to

C. S. McCauley, commander in chief of the U.S. Naval Forces in the Pacific, who

responded to on July 21, 1850 , from the U.S. Ship Savanah, anchored at Benicia,

California:

"I have had the honor of receiving your letter of July 19th, and, whilst sympathizing deeply in your domestic afflictions, I shall afford every facility within my power to further you on your way to your destination. To this end I have ordered Commander Petigru, with the Falmouth, to proceed immediately to the present anchorage of the Supply and take yourself and party, with their effects, on board, and ... without loss of time sail for the Columbia River and land you as

45 Gaines Papers, Letter to Commodore Thomas Jones, U.S. Squadron, Pacific Ocean, from Secretary of the Navy, William Ballard Preston, U.S. Navy Department, December 5, 1849, reel 3, box 6 , folder 2 , frame 00436 .

${ }^{46}$ Ibid., Letter to Commodore Thomas Jones from John Pollard Gaines, U.S. store ship Supply, July $19,1850$. 
near to your destination as circumstances will permit him to do in his own ship, consistent with her safety, though I apprehend that the Falmouth will not be able to get higher up the Columbia than Astoria, but here, I am told you will find no difficulty in getting to Oregon City as steamers run daily. ${ }^{47}$

Apparently, Gaines and other members cf his party expressed concern, in a letter written on July 23 , about the accomodation of the Falmouth. McCauley responded,

"Gentlemen, I have just received your note of the 23d inst; and regret exceedingly that the "Falmouth" does not afford sufficient accomodations to take you to your destination in Oregon -- I regret this the more because it is the only means of transportation for yourselves and party that I have at my command. ${ }^{\prime 48}$

Evidently, on July 31,1850 , the Falmouth had not yet arrived. In frustration

Gaines wrote a third note to McCauley, asking if there was not another, larger vessel, available sooner for their transportation to Oregon. ${ }^{49}$ Gaines and his party had arrived at the height of the gold rush. Consequently, there were few ships available due to seamen abandoning their posts in search of their fortune at the mines. McCauley's response demonstrates his genuine concern for the Gaines party:

"I have the honor to acknowledge the receipt of your note of yesterdays [sic] date.- I regret that the Falmouth is the only means of transportation that I have now at my command for yourself and party to Oregon. I concur with you in the opinion that, from the limited accommodations of a sloop-of-war, there will be many inconveniences to contend with by so large a part - particularly by the ladies; but Captain Petigru has assured me he will do everything in his power to

\footnotetext{
47 Gaines Papers, reel 2, box 4, folder 2, frame 00483. Letter to John P. Gaines, Govemor of Oregon, from Charles S. McCauley, dated U. S. Ship Savannah, Benicia, Califomia, July 21, 1850.

48 Ibid., frame 00486. Letter to Govemor Gaines, Judge Strong, and General Hamilton from C. S. McCauley, dated U. S. Ship Savannah, Benicia, Califomia, July 26, 1850.

49 I have found no record of the second letter sent; however, since there is a reply from McCauley I can only assume Gaines sent a third note to him
} 
make them comfortable. It is to be hoped too, that the voyage will be short, the distance to the Columbia River is trifling, and, with anything like a favourable time, it ought to be accomplished in a week-and at this season of the year no decidedly bad weather need be apprehended. ${ }^{, 50}$

So, on August 3, 1850, the Gaines party boarded the U.S. Sloop of War Falmouth, leaving the San Francisco harbor. The last fifteen days of the voyage were "exceedingly pleasant," for all on board. ${ }^{51}$

After a journey of seven-and-a-half months, the Gaines party arrived at Astoria on August 15, 1850. Upon his arrival, Gaines met with customs officials briefly to transact a small amount of government business. ${ }^{52}$ The party departed Astoria, the same day as they had arrived, on board a steamer which took them to Oregon City. Arriving the next day, the Gaines party discovered Oregon City to be not "so beautiful or commanding in appearance as expected ...." country, as seen from the river, looked as if it could compete "with some of the most flourishing States of the Union ...," wrote Archibald. "[T]hough I must say that I have met with nothing, as yet, that I like so well as the good old State of Kentucky.".54

${ }^{50}$ Gaines Papers, reel 2, box 4, folder 2, frame 00490. Letter to John P. Gaines, Govemor of Oregon, from Charles S. McCauley, dated U. S. Ship Savannah, Sausalito, Califomia, August 1, 1850.

51 Archibald K. Gaines Journal.

52 Gaines Papers, Letter to Commodore Thomas Jones, July 19, 1850, reel 3, box 6, folder 2 , frame 00436.

${ }_{53}$ Archibald K. Gaines Journal.

${ }^{54}$ Ibid. For further discussion about voyages around Cape Horn, see Paul G. Merriam, "Riding the Wind: Cape Hom Passage to Oregon, 1840s - 1850s," Oregon Historical Quarterly, 1976, pp. 36 60 . 


\section{Chapter Six}

\section{A WHIG APPOINTEE IN A DEMOCRATIC TERRITORY}

"In standard texts Gaines is characterized as vain, pompous, arbitrary and unavailable. He may have been reser sed. He had reason enough. On the voyage out, two of his daughters died of yellow fever. The remainder of the accepted description is suspect. It issued from men who, because they opposed Gaines, did not hesitate to malign him. The governor's true deficiency was political. He was a Whig appointee in an overwhelmingly Democratic territory."1

Anchored at the mouth of the Columbia River, the Gaines party patiently awaited a conveyance into the territory they would now call home. While waiting,

Gaines received a note from the citizens of Washington County in that said,

"It will be a . . heartfelt congratulation to the citizens of the Territory at large to welcome you upon your safe arrival with your family ... after your long and varied voyage. They will feel too a sincere sympathy with yourself and family occasioned by the [calamities] which have made your voyage painfully eventful. None will experience their mingled feelings of sorrow and satisfaction more keenly than our fellow citizens of Washington County. . . [ []t will be highly gratifying if your Excellency will notify either of us, (in advance) of the hour of your arrival at Portland-- in order that we may secure such arrangements to be made to give such a public reception to yourself and the official gentlemen who accompany you, as may be fitting to the occasion. ..." 2

Cannon fire, mixed with salutary speeches, greeted the Gaines party in Oregon

City as they stepped from their steamer that warm afternoon of August 16, 1850.

Shortly after arriving the party gathered at a dinner in their honor, during which

Governor Gaines presented the people of Oregon with a silk American flag and a salutation from Oregon Territorial Delegate Samuel Thurston. This gesture is

\footnotetext{
1 Clark, p. 245.

${ }^{2}$ Gaines Papers, reel 2, box 4, folder 2, Frame 00487 . I cannot ascertain who actually wrote this letter or the date of the letter because of fire damage.
} 
significant because until that time the Federal Government had not given Oregon

an American flag -- the symbol truly represented the United States welcoming its

territory on the Pacific Coast to the Union.

Of the other territorial officials accompanying Governor Gaines to the

reception dinner, Edward Hamilton ${ }^{3}$ succeeded Oregon Territorial Secretary

Kintzing Pritchette, and William Strong ${ }^{4}$ filled a vacancy caused by the

resignation of Peter $\mathrm{H}$. Burnett ${ }^{5}$ on the territorial supreme court. J. B. Preston ${ }^{6}$

${ }^{3}$ Bancroft, p. 139; Coming, p. 105. Bom in Culpeper County, Virginia, on October 3, 1801, Hamilton was a lawyer by profession. He edited the Portsmouth Tribune in Portsmouth, Ohio, before coming to Oregon. Serving as a captain under General Zachary Taylor in the Mexican War, Hamilton became a General through his service in the militia. At the Whig convention, held at Philadelphia in 1848, he nominated Taylor for president. He formed a law practice with Benjamin Stark at Portland in 1854. He also served as secretary of the Oregon City Female Seminary that year. Besides serving in the position of Oregon's second temitorial secretary (August 18, 1850 to May 14, 1853), Hamilton also served as a Multnomah County judge from 1858 to 1862 . He mamed Katherine Royer in Ohio in 1850; they had at least one child. Hamilton passed away on December 10 or $12,1883$.

${ }^{4}$ Coming, p. 235-236; Bancroft, p. 139. Bancroft refers to Strong as James Strong, however, I have verified his name as William Strong. Bom July 15, 1817, in New York, William Strong gained his early education near a town named Rushville. He attended Yale College, entering there at age seventeen, and graduating in 1838. After graduation, Strong continued his study of law, taught school, and passed the bar exam in 1840. He mamied Lucretia Robinson the same year and they eventually had six children. Strong began practicing law at Cleveland, Ohio in 1840, continuing in that capacity until 1849, when Presicent Taylor appointed him associate justice of Oregon's Temitonal Supreme Court. He presided over the Third District. Moving to Cathlamet on the lower Columbia in the spring of 1851 , he became the sole judge of the newly created Washington Temitory in 1853. He practiced in the courts of both Oregon and Washington from 1853 to 1855 . When Indian troubles arose in 1855 , Strong volunteered his services to the cause. He also surveyed public lands, advised Govemor Isaac I. Stevens, and became a member of Washington's House of Representatives in 1856. In 1858 Strong became an associate judge in the Supreme Court of the Washington Temitory, serving in that capacity until 1861. In 1862 he moved to Portland and practiced law there until 1883. He passed away on April 10, 1887.

${ }^{5}$ George H. Himes, "History of the Press of Oregon, 1839 - 1850," The Oregon Historical Quarterly, V (1904), p. 345; Coming, p. 38. Bom November 15, 1807, in Nashville, Tennessee, Peter Hardeman Bumett had relatively little education and worked as a store clerk until 1832 . He mamed Hamet W. Rogers that year and moved to the Missour frontier. Falling into debt, but nonetheless pursuing the study of law, Bumett began practicing law in 1839. In 1843, still in debt but determined to improve his condition, he embarked on the Oregon Trail reaching. He arrived in Oregon in the fall of 1843 and settled on a farm near Linnton. Shortly thereafter he moved to another farm near Hillsboro and became active and well known locally. In 1844 he served as one 
later joined Gaines and the other federal officers in April of 1851, becoming the

Oregon Territory's first Surveyor General. Strong served as the Oregon

Territory's sole judge for eight months because O. C. Pratt, ${ }^{7}$ also a judge on the

supreme court, had "slipped away to California and the East immediately upon

hearing that a new colleague was approaching Oregon." His purpose in the East

was to solicit for himself the position of chief justice of the Territorial Supreme

Court. $^{8}$ Ironically, on his return trip to the Oregon Territory Pratt accompanied

of the nine committee members of the Provisional Govemment and in 1845 he became judge of the Supreme Court. His peers elected him to the Oregon Territorial Legislature in 1848, and the same year President Polk appointed him Supreme Court Justice. Having already left for the mines of Califomia, Bumett never served in the capacity of Supreme Court Justice; however, he became Califomia's first govemor in 1850. He never retumed to Oregon. Bumett passed away in Califomia on May 17, 1895. For further reading on Peter Bumett see his book, Recollections of an Old Pioneer, published in 1880.

6 "Pioneer days." This article claims Preston came with the Gaines party to Oregon around Cape Hom; however in Corning, p. 205, Preston's biographical sketch says he amived in Oregon on April 20,1851 . Preston's original surveys fixed the "boundaries of all donation land claims in the Oregon Country. He drove the "starting stake" for the base surveys June 7, 1851. A growing number of crews served under him in the field. With the work only well begun, he was replaced in 1853 by C. K. Gardner, who broadened the scope of the surveys."

${ }^{7}$ Clark, p. 229; Coming, p. 204. Clark describes Pratt as "Suave, sleek, swollen with self-esteem, incurably covetous ... slippery as a greased eel." Moreover, he adds, "Comers of his career are shadowed by little mysteries intended to conceal indecorous truths." Clark further refers to Pratt's first name as Oliver on page 229; however, the name appears as Orville under his photograph in the middle section of the book. I checked on this, and Pratt's first name is indeed Orville. Bom on April 24, 1819, in Ontario County, New York, Orville C. Pratt, attended West Point Academy from 1837 to 1839. After studying law at Rochester, New York he gained admittance to the New York bar in 1841. He practiced law at Galena, Illinois from 1843 to 1849 . It is probable Pratt had a family in Galena, but for some unknown reason left them in Illinois instead of bringing them to Oregon. Clark says, "On going East, [in 1851] Pratt had visited Galena long enough to impregnate his wife (relieving himself of the necessity of moving her to Oregon)." Nonetheless, in 1849 Pratt came to Oregon as a justice of the Territorial Supreme Court and remained in that capacity through 1856. Pratt left Oregon for California in 1856, and died at San Francisco in October 1891.

${ }^{8}$ Clark, pp. 243, 251. 
newly appointed Chief Justice Thomas Nelson. ${ }^{9}$ Pratt would later cause Gaines and his colleagues much mental anguish.

A short time after his arrival, Gaines received a letter from his friend in Congress, Mr. J. R. Underwood, that read,

"I have at length the happiness to inform you that your nomination has been confirmed by the Senate by a vote just taken. It was unanimous in your favor with the exception of the two Senators. ..." ${ }^{10}$

Thus, he was now the officially confirmed Governor of the Oregon Territory. John Pollard Gaines arrived in Oregon a Whig and an outsider -- carrying with him an emolument not highly regarded by the communities of the territory. The Oregon Territory -- which extended to the original boundaries fixed by the treaty of 1846 -embraced all the region now contained in Oregon, Washington, Idaho, and the western portions of Montana and Wyoming. Its main population, at the time of Gaines's arrival, centered in the northern Willamette Valley. Governor Gaines faced an intensified individualism found in the territory's inhabitants -- a reflection of Oregon's successful Provisional Government and the lack of federal assistance from the United States. The long period of relative federal neglect

\footnotetext{
${ }^{9}$ Ibid., p. 251; Coming, p. 174. Bom at Peekskill, New York on January 23, 1819, Thomas Nelson received his license to practice law in 1840. Appointed Chief Justice of the Oregon Territorial Supreme Court in 1850 by President Millard Fillmore, Nelson amived at Oregon City in April 1851, and served with Associate Justices Orville C. Prati, and William Strong. Political controversy surrounded his three year term in the Oregon Temitory, "but he executed his duties with honor." Leaving the territory in August of 1853, Nelson retumed to New York where he practiced law. He visited the State of Oregon, forty years after his departure from the Temitory, in July of 1889. Nelson passed away on July 26, 1907.

${ }^{10}$ Gaines Papers, reel 2, box 4, folder 2, Frame 00505. Letter to Govemor Gaines from J. R. Underwood, dated Washington, September 1, 1850.
} 
aroused in them irritations that only the most sage of diplomats might have soothed.

The early years of a territory's organization were often "disruptive, confused, intensely combative, and highly personal" politically - the term Kenneth Owens uses to describe the quagmire of early territorial organization is chaotic factionalism. ${ }^{11}$ Common reasons for chaotic factionalism in frontier territories include a small population and a smaller political community -- or "persons actively interested and involved in politics." The Oregon Territory of the early 1850 s had relatively few settlements, some of them a great distance from others. A steady stream of immigrants brought with them their political ideals -- likes and dislikes toward certain forms of government; however, a truly settled social and political order had yet to form because the early settlers' main concerned was providing for their families.

When Asahel Bush departed for Oregon, Delegate Samuel Thurston sent with him two letters of introduction: one to his Democratic colleagues in Linn County and another to his Democratic colleagues in Yamhill County. These letters urged them to lend Bush their aid and influence, "patronize his enterprise . . . and further his design." ${ }^{13}$ Thurston's "design" for Asahel Bush consisted of

\footnotetext{
${ }_{11}^{11}$ Kenneth N. Owens, "Pattem and Structure in Westem Temitorial Politics," Bloom, p. 163.

12 Ibid., p. 164.

13 "Political Correspondence." Letter dated November 30, 1850. Again, it appears Thurston was in a race with the Whigs regarding who would establish the first party paper.
} 
building a strong Democratic Party in Oregon and to that end, creating a newspaper as the voice of the organization. On November 30, 1850, Thurston wrote a letter to Bush telling him he had found a newspaper press in New York, but that it would need repair upon its arrival in Oregon. He urged Bush to "Drive this thing ahead at all hazards... The enterprise cant [sic] fail -- it will be triumphant." Thurston warned Bush to keep his correspondence a secret. ${ }^{14}$ Soon after Bush arrived in Oregon, he began "undercutting his designated associates" of the Oregon Statesman. ${ }^{15}$ Wilson Blain, a friend and associate of Thurston's involved in the planning of the Statesman, was Bush's first target. ${ }^{16}$ Writing a letter to Thurston, Bush accused Blain of leaking secrets and Henry Russell of being "careless with money."17 On December 19, 1850, Henry Russell transferred his interest in the Statesman over to Bush. ${ }^{18}$ Apparently Russell had assumed he would be in charge of the editorial matters. In a letter dated January

\footnotetext{
${ }^{14}$ Ibid. Thurston did not want local Whigs to catch wind of the eminent production of a Democratic paper, nor his connection with it.

${ }_{15}$ Clark, p. 244.

${ }^{16}$ Himes, pp. 354 - 355. The Rev. Wilson Blain, a clergyman of the United Presbyterian Church in Oregon City, edited the Spectator newspaper from October 1849 through September 5, 1850.

Bom in Ross County, Ohio, on February 28, 1813, Blain graduated from Miami University, Oxford, Ohio, in 1835. His continued his studies at the Associate Reformed Theological Seminary, Allegheny, Pennsylvania, and received his license to preach on April 18, 1838, from the First Presbytery of Ohio. After being ordained by the Presbytery of Chillicothe, Ohio, on October 17, 1839 , he became pastor of the Presbyterian congregation at Hebron, Indiana, until May 8, 1848, when he departed for Oregon. Soon after his amival at Oregon City, on November 29,1848 , Blain organized the first Presbyterian Church in the temitory. After being elected to the temitorial legislature on June 6,1849 , he moved to Union Point, Linn County, organizing another church there in November 1850. Blain also established, managed, and taught at a Presbyterian academy at Union Point. He died on February 22, 1861.

17 Clark, p. 244; Tumbull, p. 77.

18 "Political Correspondence." The letter transfeming the press and materials is dated December 19,1850 , at Oregon City.
} 
17, 1851, Bush informed Thurston he preferred Russell have nothing to do with

the paper:

"Taking all things into consideration I am positive that it would be better if he was not connected with it. And I had much rather be alone in the concern. Russell makes a bad impression wherever he goes. So they all tell me."19

Thurston never responded to Bush's January 17 letter, but referred to Russell in a letter dated January 27,1851 , saying

"In no case is he to have any control over the editorial part of the paper. It was understood that he was to be, with Stockwell, the mechanical partner . . Now sir, in no event allow him to manage the finances of the concern . . ." ${ }^{\prime 20}$

Stockwell resigned from the partnership in the Statesman before Bush had a chance to attack him -- which left Bush sole proprietor, publisher, and editor of the Democratic mouthpiece.

Bush was not a man who wasted time. While waiting for the Oregon Statesman press to arrive, he solicited subscriptions to the paper. Assisting him in this endeavor were Matthew Deady, ${ }^{21}$ James Nesmith, and Joseph Avery, ${ }^{22}$

\footnotetext{
19 Tumbull, p. 77.

20 "Political Correspondence." Letter dated January 27, 1851, Washington City.

${ }^{21}$ Hendrickson, page 26n; Corning, p. 70. Born in Maryland in 1824, of Insh ancestry, Matthew
} Paul Deady received his early education in West Virginia. He became a blacksmith by trade, then after receiving further educational training at the Bamesville Academy in Ohio, he passed the Ohio bar in 1847. Arriving in Oregon in 1849, Deady taught school and practiced law at Lafayette. Elected to the Oregon Temitorial Legislature in 1851, Deady became associate justice for the southem district of the Oregon Ternitorial Supreme Court in 1853. In 1852 Deady mamed Lucy Henderson and they had three children. Residing in the Umpqua Valley until after Oregon became a state, Deady wrote a provision in State law "prescribing six-year terms for judges, biennial sessions of the legislature, and four-year terms for state officers." President James Buchanan appointed him United States District Judge for Oregon in 1859, at which time he moved to Portland, living there until his death. Deady was also among the founders of Multnomah Public Library, and served as president for the Board of Regents of the State University from 1873 to 1893. Passing away on March 24, 1893, Deady was "a brilliant and articulate jurist," and one of Oregon's "most distinguished citizens." 
who traveled up and down the Willamette Valley selling the Statesman. Besides helping Bush with his enterprise, these men became influential in their own right during the later part of the nineteenth century: Deady became a judge, Nesmith a politician, and Avery a newspaper man. Bush and Deady became instant friends -- they got along so well that they became roommates in Oregon City during the winter of $18500^{23}$

A few miles down river from Oregon City, the leading businessmen and founders of a new village called Portland were eager to start their own local paper. Milwaukie (near Oregon City) had the Western Star, ${ }^{24}$ Oregon City had the Spectator, ${ }^{25}$ and Bush waited anxiously for the arrival of the Statesman's press. During the summer of 1850 , while waiting for their new governor to arrive,

${ }^{22}$ Avery later parted ways with Bush over a political disagreement. Coming, p. 15. Bom on June 9, 1817, at Punckhammock, Pennsylvania, Joseph Conant Avery, received his education at Willkesbarre, Pennsylvania, and moved to Illinois in 1839. He mamed Martha Marsh in 1841 and in 1845 he left for Oregon. Avery settled on the Mary's River in the upper Willamette Valley and operated a ferry on the Willamette River. Working hard at "planting and harvesting crops" Avery also built a log granary before leaving for the Califomia gold mines in 1848 . Retuming in 1849 with a small fortune in gold, he bought "a stock of goods . . . and opened the first store" at the townsite he had surveyed and platted. The town became Marysville, and later Corvallis. In 1853 Avery was appointed postal agent for the temitories of Oregon and Washington. He also served for two terms in the Temitorial Legislature as a representative of Benton County. Avery died on June 16, 1876.

${ }^{23}$ Clark, p. 244

${ }^{24}$ Bancroft, p. 147; Himes, 361 - 362. The Westem Star issued its first number on November 21, 1850. Lot Whitcomb, a native of Vermont and founder of the town of Milwaukie, onginally owned the Star. John Orvis Waterman later bought the Star and moved the paper to Portland, renaming it the Oregon Weekly Times. The first issue of the Times came out on June 5, 1851.

${ }^{25}$ Himes, p. 337-338. The Spectator has the distinction of being Oregon's first newspaper.

Founded before Oregon became a temitory, the Spectator's first issue came out in Oregon City on February 5, 1846 with the motto "Westward the Star of Empire takes its Way." John Fleming, an immigrant of 1844 from Ohio and postmaster of Oregon from 1856 through 1869, printed the Spectator. The Spectator's first editor was William G. T'Vault, pioneer of 1845 . T'Vault, a native of Kentucky, was also the Oregon Provisional Govemment's postmaster general. 
Stephen Coffin and W. W. Chapman ${ }^{26}$ traveled to San Francisco to locate a press for their proposed paper. In early July they met T. J. Dryer, the editor of

San Francisco's California Courier, who happened to be thinking about relocating. It did not take much for Chapman and Coffin to persuade Dryer to come north to Portland and become editor-in-chief of The Weekly Oregonian.

Born in Canandaigua County, New York, on January 10, 1808, Thomas Jefferson Dryer was the second child born to Aaron and Lucinda Dryer. When young Thomas was twelve-years-old, and shortly after the family had moved to Ohio, Lucinda Dryer passed away. Aaron Dryer soon remarried, and after about three years living in an intolerable family situation, Thomas left Ohio, returning to

\footnotetext{
${ }^{26}$ Coming, p. 51 and 57; Himes, p. 363. Himes says of Coffin and Chapman that they were "leading citizens of Portland . . . and vitally interested in everything pertaining to its well being. ...." Bom on August 11, 1801 William Williams Chapman received his early education in Clarksburg, Virginia. He studied law and moved to the Wisconsin Temitory. He served as U. S. Attomey while there, and upon moving to the lowa Teritory he was elected to Congress. In 1832 Chapman mamied Margaret I. Ingram and they had seven children. Moving to Oregon in 1847, he settled in Linn County, then moved to Salem. He left for the Califomia gold mines in 1849 , retumed in the company of Govemor Joseph Lane in 1850 , and was elected to the Oregon Temitorial Legislature. Purchasing a one-third interest in the new townsite known as Portland in 1850, Chapman then moved to Fort Umpqua in 1853, where he bought holdings of the Hudson's Bay Company and began a mercantile business. In 1855 and 1856 he participated in the Rogue River Indian Wars after which he moved to Corvallis for a year. In 1857 he moved to Eugene where he became Oregon's Surveyor General. Resigning that position in 1861, he retumed to Portland practicing law there for a number of years. Chapman passed away on October 18, 1892. Bom in 1807 and a native of Maine, Stephen Coffin amived at Oregon City in 1847. In 1849 Coffin purchased halfinterest in the future townsite of Portland and in 1860 he helped form the People's Transportation Company. Providing a steamboat at his own expense along with blankets and provisions, he transported military troops up the Columbia River at the outbreak of the Yakima Indian War. Govemor Addison C. Gibbs appointed him brigadier-general of the militia in 1863. He was very instrumental in building the Tualatin Plank Road, (now known as Canyon Road), and a large stockholder of the Oregon Iron Works of Oswego. Coffin built the first pine saw mill at Eastem Oregon, near La Grande in 1862 . Further, he contracted to build twenty wooden bridges; "donated a public levee to Portland; purchased Portland's first church and school bell; and with W. W. Chapman gave two blocks to M. E. Church as the site of academy for boys and seminary for girls." Coffin passed away on March 15, 1882.
} 
New York. He eventually found work as a mail carrier and continued in that capacity, saving money all the while until 1841. At that time he left for Michigan, spent some time there, and then moved on to Indiana. He gained experience working at newspapers along the way, and in 1849 , hearing about the California gold rush, he left for that state from St. Louis, Missouri. So, at age forty-three, Dryer arrived in California. He soon found a job as the city editor of the California Courier and just as he became dissatisfied with his situation he met Chapman and Coffin. ${ }^{27}$

Dryer brought with him to Portland an "old Ramage press ... with some second-hand material, which answered his purpose for a few months until a new Washington press and new material came out by sea from New York. ..." ${ }^{28}$ The Milwaukie Star informed its readers:

". . [A] press, type, and paper, intended for the Oregonian, is on board the bark Keoka, which is now in the river near Portland. We shall look for the Oregonian in a few weeks. We understand it is conducted by T. J. Dryer, Esq., formerly the city editor of the California Courier. Mr. Dryer has the reputation of being an able man, and now doubt will furnish the reading community with a good, readable paper." ${ }^{29}$

In the meantime, Asahel Bush's popularity grew and he developed a following of politicians of the Democratic persuasion. When the territorial legislature convened in December of 1850 , its members elected Bush to the

\footnotetext{
27 Tumbull, pp. 56-57.

${ }^{28}$ Bancroft, p. $147 \mathrm{n}$.

${ }^{29}$ Tumbull, p. 56.
} 
positions of territorial printer (even though his press had yet to arrive) and chief

clerk of the assembly. ${ }^{30}$ It was during the legislative session that Bush met

Reuben P. Boise ${ }^{31}$ and Benjamin Harding, ". . a shy, good looking lawyer, a

gentle manipulator." Harding and Bush remained close friends until death

separated them. ${ }^{32}$ Boise, Deady, Harding, and Nesmith became the heart of

what later became known as the "Salem Clique," a group of power-hungry

${ }^{30}$ Clark, p. 244; Flora Belle Ludington, "Oregon Newspapers 1846-1870," Oregon Historical Quarterly, XXVI (September 1925), pp. 256-258. Bush remained in the position of Territorial Printer until the rise of the Republican Party and the "growing power of the Oregonian" caused his defeat and replacement by Henry Pittock.

${ }^{31}$ Coming, p. 31. Bom at Blanford, Massachusetts, on June 19, 1819, to Reuben and Sally

Putnam Boise, Reuben Patrick Boise graduated from Williams College in 1843 and passed the Massachusetts Bar in 1847. He came to Oregon in 1850 and mamed Ellen Frances Lyon the next year. They had two sons. In 1853 Boise joined with James K. Kelly and D. R. Bigelow in prepaning the first code of laws for Oregon. He practiced law in Portland until 1857 when he was appointed a Justice of Oregon's Territorial Supreme Court. When Oregon became a state in 1859, Boise was again elected to the Supreme Court, serving as Chief Justice from 1862 to 1864, and leaving the bench in 1870. In 1867 Boise married Emily $A$. Pratt and they had two daughters. He retumed to the bench of the Supreme Court in 1876, serving in that capacity until 1880 when he became Circuit Judge of the Third Judicial District, in which capacity he served until 1892. After six years in private practice, Boise again attained the position of Circuit Judge from 1898 until his retirement in 1904. Boise also served as a trustee of Pacific University, La Creole Academy, and Willamette University. Moreover, he served as a regent of Oregon Agricultural College, was master of the Oregon State Grange for five terms, and was proprietor of Ellendale Woolen Mill. He passed away on April 14, 1907.

32 Clark, p. 244; Coming, p. 106. Benjamin Harding was bom in Wyoming County, Pennsylvania on January 4, 1832. After studying law he gained admittance to the Illinois Bar in 1849. He moved to Oregon approximately 1850 and settled in Marion County. Elected Clerk of the Territorial Legislature in 1851, he also served as a member of the Legislature and Speaker of the House in 1852. He married Elizabeth Cox in 1851 and they had several children. President Pierce appointed Boise United States District Attomey in 1853, replacing Amory Holbrook. Pierce appointed him Oregon Ternitorial Secretary in 1855, in which capacity he served until 1859. Boise served as one of the first commissioners on the Eugene-Oregon City-Portland project of the Oregon-Califomia Railroad Company, incorporated in 1854. Elected to the Oregon Legislature again in 1858 , and serving in that capacity until 1862 , he was speaker of the assembly during the 1860-61 session - the first regular session after Oregon became a state. A Douglas Democrat, Boise "was one of the ruling spints of the Union cause." He became a United States Senator, as a Republican, on September 12, 1862, serving as such until March 3, 1865. Following the death of his first wife, Elizabeth, Boise remaried in 1868 to a Mrs. F. W. Bush, a relative of Asahel Bush. Retining to his Manion County farm, Boise lived for a time in Salem, but later moved to Cottage Grove where he passed away on June 19, 1899. 
Democrats bent on controlling the government of the Oregon Territory. Asahel Bush became the voice and leader of the clique through the Oregon Statesman.

Thus, while he waited impatiently for the press of the Oregon Statesman to arrive, Bush made sure of his position as leader of Oregon's new Democratic Party.

On December 2, 1850, the legislative assembly invited Governor Gaines to speak before them. Gaines began:

"The duty is not imposed on me by law, to recommend, to your considerations, any measure, nor am I clothed with power to approve or disapprove any of your acts. But in accordance with previous usage, and believing that some suggestions from them will not be unacceptable to you, I have taken some pains to ascertain the wants and necessities of our common constituents, and with great deference submit a few observations to your consideration." ${ }^{33}$

In the remainder of his address, Gaines referred to the letter he wrote to President Taylor while at Washington City the previous December. He told the assembly that he furnished a copy of this letter as a part of his communication to them. He went on to discuss the increased emigration to Oregon, donation land claims, military protection, and the importance of creating, improving, and maintaining roads within the territory.

". . To connect the Puget's Sound with the Columbia [R]iver, some point on the Willamette with the mouth of the Columbia, and the Willamette [V]alley with that of the Umpqua, are among those I would name for the present. Commissioners should be appointed to view, locate, and mark out the principal roads at the expense of the Territory, and the counties through which they pass, required to open, and keep them in good order., ${ }^{34}$

${ }^{33}$ Oregonian, December 4, 1850, p.2.

${ }^{34}$ Ibid. 
His concern centered not only on roads, but also rivers:

"To the Federal Government properly belongs the improvement of our rivers and habours. . . I learn from the collector's office that out of one hundred and seventeen vessels that have entered the mouth of the Columbia [between] April 1849 and September 1850, there has been but two vessels that have met with accidents, only one of which was lost. ... The numbers of vessels arriving and trading on the Columbia and the Willamette is rapidly increasing each month. . . . We may reasonably expect, I think, further appropriations by the General Government for the erection of light houses and other improvements." ${ }^{13}$

Gaines continued his speech with a discussion of the need for institutions of

education, buildings for "public business," and "the permanent location of the seat

of Government." Regarding the location of the territorial capital, Gaines said,

"This subject is well calculated to excit€ the public mind, therefore, great pains should be taken to meet the just expectations of all parts of the Territory. The advantage, in a pecuniary point of view, of the location, to the place selected is rather imaginary than real. As, therefore, there can be but little individual gain or loss, the subject has no importance in this sense, but the public at large have a deep interest that a judicious selection be made. There is now in my hands $\$ 5,000$ for the purpose of erecting suitable public buildings, to which may be added $\$ 40,000$ appropriated at the late session of Congress. ${ }^{.6}$

Gaines concluded his remarks on public buildings with a comment on the

necessity for a penitentiary as "a secure place of confinement for persons

convicted of high crimes."

Regarding the Indians living in the territory Gaines said,

"In relation to that portion of Indian tribes who are within the settled part of the Territory, a high and sacred duty belongs to the Legislature. The protection of these people in their homes and persons, the guardianship of their moral being, the bestowal upon them of such cultivation as they are capable of receiving, in a great measure belongs to the General Government. The Government has

35 Ibid.

${ }^{36}$ Ibid. 
appointed a person whose especial duty it is to attend to Indian affairs, and a Board of Commissioners to treat with the Indians for the relinquishment of their right to the soil.".37

He continued his discussion about Oregon's Native Americans, mentioning an apprentice program for Indian children that would train them in "useful trades and occupations" provided their parents gave their consent. Although the Indians may at first be resistant to the program, Gaines said,

". . . their habits of fixed residence, and great unwillingness to leave their old grounds, the ingenuity displayed by them in many articles of manufacture, indicate the direction in which they should be instructed, not only as farmers, but as carpenters, smiths, and other mechanical pursuits. . Should the experiment be deemed worthy a trial . . . provision should be carefully made in it, for the protection of the apprentice in his rights, and authority given to the agents of Government to enforce the fulfillment of the contract on the part of the employers." 38

Gaines next commented on the ccndition of laws in the territory:

"No man's life, liberty, or property, should be subjected to the operation of laws of which he is wholly ignorant, or of which he might not easily obtain information and yet, such is essentially the condition of the people in the territory. ${ }^{39}$

He complimented the people of the territory on their "love of good order" and respect for the rights of each other; however, he cautioned the legislative assembly, stating,

". . [A]s the country populates, new interests will arise, and the necessity of well known rules, by which these interests can be regulated and protected, must be obvious to all. Some of the laws now on the Statute Book, are believed by many to have been placed there in violation of their chartered rights, whilst others openly refuse obedience to them for the same reason. These difficulties should

37 Ibid.
38 Ibid.
39 Ibid. 
be gotten rid of, and a code instituted that would command the respect of all our constituents." 40

On the subject of taxation, Gaines proposed the passage of an equitably levied property tax law, "by which the value of every person's property, of every description, is duly ascertained, " and a uniform tax applied to it. ${ }^{41}$

Referring to the territorial library, Gaines comments,

"The unexpected balance of five thousand dollars appropriated by Congress for the purpose of purchasing a library, was placed in my hands, and has been nearly all expended under my direction. The books have been placed in a room handsomely fitted up, and I submit to your wisdom such action in relation to them as you think proper. If it is your desire to provide for their use and safe keeping at the Territorial expense, they are at your disposal, otherwise I will endeavor to see the law faithfully executed." ${ }^{42}$

Gaines also commented on the Washington Monument being built at Washington City. Since other states and territories of the Union were each contributing a stone to the monument, Gaines invited the citizens of the Oregon Territory to do the same with a "suitable insscription thereon, to form a part of the monument." He said, "In recommending an immediate acceptance of this invitation, I feel sure that I am expressing the wishes of every true hearted Oregonian." ${ }^{43}$

In his closing remarks Gaines commented on the death of President Taylor in Washington City on July 9, 1850. Gaines's final words to the assembly

\footnotetext{
${ }^{40}$ Ibid.

41 bid.

${ }^{42}$ Ibid.

${ }^{43}$ Ibid.
} 
spoke of the safety of the United States and his expected cooperation with the assembly regarding affairs in Oregon:

"The admission of California into the Union, the establishment of Territorial governments in Utah and New Mexico, and the proposition to settle the Texas boundary question which I have no doubt will be occupied by that State, has scattered to the winds the oft repeated declaration of monarchists, 'that there is no capacity in man for self government,' it is a timely rebuke to fanaticism both North and South. I invoke the Divine blessing on all your efforts to serve Oregon, and tender you my hearty co-operation." ${ }^{44}$

The Oregonian newspaper rolled its first issue off the old Ramage press on December 4, 1850, printing in its pages Governor Gaines's first address to the Legislative Assembly, his letter to President Taylor, and the Donation Land Claim Act. With Dryer at the helm, the Oregonian quickly became a thorn in the side of Asahel Bush. Not only did it issue its first number before Bush's Statesman, it was also a proponent of the Whig Party in Oregon -- and Thomas J. Dryer soon proved himself "a man of ability ... an excellent speaker and an aggressive fearless writer well suited for pioneer journalism." ${ }^{45}$

On Christmas day 1850 Governor Gaines appeared with many other local citizens who gathered to witness the launching and christening of the first steamboat built on the Willamette River. The steamboat "was a first-class vessel: double boiler, twin stacked, with galley, dining salon and plenty of cabin space."46 Much experience came with the Lot Whitcomb: Jacob Kamm installed her

\footnotetext{
44 Ibid.

45 Tumbull, p. 56.

${ }^{46}$ Clark, p. 243.
} 
machinery and commanding the vessel was Captain John Ainsworth -- both individuals gained their experience on the Mississippi River. Holiday spirit and great excitement charged the atmosphere as cannon salutes reverberated through the countryside. At the appointed hour, Governor Gaines christened the vessel and sent it into the Willamette River. Just before the boat hit the water a cannon exploded, instantaneously killing Captain Frederick Morse, commander of the Merchantman. Despite this tragic event, the Lot Whitcomb began service immediately and thereafter made regular excursions between Oregon City and Astoria. $^{47}$

Three months later, on March 28, 1851, the first issue of the Oregon Statesman finally hit the streets and most Democratic homes in Oregon received and read it with interest. ${ }^{48}$ Bush's journalistic style proved to be "cold, calculating, [and] relentless." The Statesman quickly became the "Bible of Oregon Democracy," ${ }^{49}$ with Bush holding the reins of power of Oregon's Democratic Party during the remainder of the territorial period and a few years into statehood. Aspiring politicians and businessmen, who contributed to the columns of the Statesman, rose to distinguished positions in the territory "by the dozen. ${ }^{150}$ The first and subsequent issues of the Statesman declared in the

47 Ibid.; Carey, pp. 651-652.

48 Tumbull, p. 80.

49 Ludington, p. 256.

50 Bancroft, p. $147 \mathrm{n}$. 
banner, "No favor sways us, no fear shall awe." ${ }^{51}$ Indeed, the paper and its editor boldly defied the federally appointed officials and federal laws as applied to the territory.

The citizens of Oregon became concerned about the federal government's distance and apparent lack of disregard for their welfare as early as March 1850. Governor Lane was off dealing with Indian affairs and Judge Pratt had left for the East Coast. The Spectator announced,

"[W]e are in a state of anarchy. We have no civil officers, and what is worse, there is, so far as we know, no legal way of creating any. . . So far as we can see there is no remedy for this state of things but in the erection of a State Government and the elevation of our own officers. . . . And we are strongly inclined to the opinion that if all our officers were dependent on the voice of the people for their official tenure, our business would be attended more promptly." 52

Thus, a revolt against the territorial system of government had begun.

A passion for home rule continued to fester in the territory and about six months after Governor Gaines arrived citizens in Portland gathered to prepare a resolution of protest. They belligerently declared ". . there are many respectable individuals in Oregon capable of ... filling any ... office under the territorial government. ..."53 The Oregon Statesman published the resolution, which targeted not only Gaines, but all federally appointed officials, on April 11, 1851. Moreover, the Oregon Territorial Legislature, in December of 1851 and

51 Webb, p. 6.

52 Dorothy O. Johansen, "A Tentative Appraisal of Territorial Government in Oregon," Pacific Historical Review, XVIII (November 1949), p. 493.

53 Carey, pp. 503-504. 
January of 1852 , took action against federally appointed officials and sent a memorial to Congress. The memorial, in essence, requested an amendment to the Organic Act to enable Oregon's citizens the right to elect their local officials.

The resolution, together with the memorial to Congress, demonstrates the deep resentment felt by the citizens of Oregon toward outside appointees and the fifty-five-year-old Gaines seemed to personify what they despised most -- he appeared to them as a "vain, pompous, arbitrary, and unavailable" politician. ${ }^{54}$ Coming, as he did, from a fairly well to-do aristocratic Kentucky family, he may have carried himself in a manner considered arrogant by the citizens of this farflung frontier. For whatever reason, local individuals considered Gaines and his peers "outsiders," and this sentiment provided a fertile bed in which to sow the seeds of the Democratic Party in Oregon.

Individuals interested in gaining personal advantages during a territory's organizational period most likely sought it through political means. According to Owens,

"Federal officials, from land office registrars to the governor and territorial judges, must be counted among them. Also included ordinarily were locally posted army officers and local supervisors or agents for such major nonterritorial enterprises as transcontinental railroads. Pre-eminent among political activists, however, were newly minted local boosters, frontier newspaper editors, lawyers, and other professional men whose careers would prosper as the country attracted more immigrants. Most important of all were frontier businessmen who had come to a new location on speculation, who were anxious through governmental means to speed the rapid growth of their business, their town, their region." ${ }^{.55}$

\footnotetext{
${ }^{54}$ Clark, p. 245.

55 Owens, p. 165.
} 
While Gaines is among federal officers and territorial judges coming into the territory, his move to Oregon did not gain him any personal advantage -- on the contrary, the move brought him much grief, both politically and personally. Asahel Bush and the Salem Clique, on the other hand, fit right into Owens's theme: they constituted a massive and dominant component in the political community of the Oregon Territory. The Clique realized that gaining control over the territorial political structure meant dictating the territory's public policy -- which directed the use of natural resources and could grant economic privileges to those in the right place at the right time. In essence, the arrival in Oregon of federally appointed Whig officials and the formation of the Clique set in motion the events that flavored the territory's first political conflict: the location war. 


\section{Chapter Seven}

\section{INEXTRICABLE AGGRAVATION AND GALLANT PERSEVERANCE}

"The act was clearly inviolate of that portion of the [O]rganic [L]aw, which distinctly states, 'that to avoid improper influences which may result from intermixing in one and the same act, such subjects as have no proper relation to each other, every act shall embrace but one subject, and that shall be expressed in the title'."1

In a special session during May of 1850 , before Governor John P.

Gaines's arrival and Governor Joseph Lane's departure, the Oregon Territorial Legislature convened at Oregon City. ${ }^{2}$ Among other things, the legislators gathered to establish "the seat of government, according to the fifteenth section of the Organic Act, which authorized the legislature at its first session, or as soon thereafter as might be expedient, to locate and establish the capital of the territory."3 One historian suggests rampant speculation and arm twisting by Speaker of the House William King and assemblyman William Willson, among others, may have occurred during the session. King, according Malcolm Clark, was "a man who could marshal the selfish desires, interests and prejudices of

\footnotetext{
${ }^{1}$ Archibald K. Gaines Joumal, March 10, 1852.

2 The first session of the Legislature assembled at Oregon City on July 16,1849 , staying in session until July, 24, 1849. Thereafter, the Legislature met in regular sessions from December through February each year until the time of statehood. The Territorial Legislature met a total of twelve times - ten regular sessions during the periods mentioned above, and two special sessions during the Gaines administration: May 1850, and July 1852. The Legislature met at several different locations during the temitorial period. It met at Oregon City during the session of 1849-50; at Salem during the session of 1851-52; again at Oregon City during the session of 1852-53; back at Salem during the session of 1853-54; at Corvallis during the session of 1854-55; and it finally retumed to Salem for the sessions of 1855-56, 1856-57, 1857-58, and 1858-59.

${ }^{3}$ Bancroft, p. 145.
} 
men with consummate skill." Willson, on the other hand, founded the town of

Salem, and probably, sought to benefit by relocating the territorial capitol from

Oregon City to that location. ${ }^{5}$

On February 1, 1851, the Legislative Assembly passed another act, titled,

"An Act to provide for the selection of places for location and erection of the

public buildings of the Territory of Oregon," which narrowly passed by a majority

of two votes. ${ }^{6}$ Disharmony abounded in the legislature that season and possibly

as a result of the desire to finish the session the legislators lumped several items

into one bill. It included the appropriation of funds for and the location of the seat

\footnotetext{
${ }^{4}$ Clark, p. 245; Bancroft, p. 143n. Colonel William M. King hailed from Washington County as an assemblyman and Speaker of the House in the Territorial Legislature. Clark describes King as being "distinguished by an illuminated nose and a conniving nature." Bom at Litchfield, Connecticut, circa 1800, King amived in Oregon in 1848. Engaging in a business at Portland, he became known "as a talented and unscrupulous politician, as well as a cunning debator and a successful tactician." King died at Portland on November 8, 1869.

${ }^{5}$ Coming, p. 271. Bom at New Harnpshire on April 14, 1805, Dr. William Holden Willson followed the trades of cooper, ship carpenter, and whaler in his early life. He studied medicine under Elijah White while on his way to Oregon in 1837. Amiving via the brig Diana, on May 18, 1837, Willson performed the duties of a carpenter and began practicing medicine at the Willamette Missions. He received his commission to preach while at the Willamette Missions and established a branch of the mission at Puget Sound in 1839. After retuming from Puget Sound, Willson took a land claim at the site of present-day Salem. He maried Chloe Aurelia Clark in 1840 and they eventually had three children. On May 2, 1843, he voted for the organization of a local civil govemment at Champoeg. Members at that meeting elected Willson Treasurer of Oregon's Provisional Govemment. Two years later, in 1845 , Willson served as President of the Bench for Champoeg County. In 1846 Willson presented land for the Oregon Institute, and the same year he platted his land claim, naming it Salem. Also in 1846, Willson became a member of the commission that sought to "borrow or raise funds for prosecuting the Cayuse Indian War." A member of the Oregon Exchange Company in 1849, he helped to develop Oregon's Beaver Money. Campaigning against Samuel Thurston as a delegate to Congress in 1852, Willson lost to former Oregon Teritorial Govemor Joseph Lane because of Thurston's untimely death. He served as a trustee of Willamette University in 1853, and as a commissioner for the projected Oregon and Califomia Railroad Company in 1854. Willson passed away on April 17, 1856, and is buried in I.O.O.F. cemetery in Salem, Oregon.

${ }^{6}$ Clark, p. 249; Carey, p. 470. Interestingly, Matthew Deady, later a member of the Clique, voted against the act.
} 
of government at Salem; a penitentiary at Portland; and a university at Corvallis. Over the course of the next two years the "location issue" would torment the federal officers sent to the territory and stir the political consciousness of all citizens living in Oregon.

Oregon's Territorial Legislature included a Legislative Assembly of two houses: a Council of nine members, and a House of Representatives of eighteen members. The qualified voters from the eight counties then existing in the Territory elected the members of the Legislative Assembly. Members increased as new counties came into existence. The individuals Gaines faced during the legislative session of December 1850 were mostly middle-aged farmers who had immigrated to Oregon between 1845 to 1847 . A majority of the legislators were from New York, Kentucky, Tennessee and Pennsylvania. The proportion of individuals from the North closely equaled that of those from the South. Most were men who had either served under or had some part in forming the Provisional Government.

Members of the 1850-1851 Legislative Council included W. W. Buck (President of the Council), Lawrence Hall, A. L. Humphrey, James McBride, Samuel T. McKean, W. B. Mealey, Richard Miller, Samuel Parker, and Frederick Waymire. Appearing as members of the House were J. C. Avery, Hector Campbell, Matthew P. Deady, S. M. Gilmore, Benjamin F. Harding, H. N. V. Holmes, William King, W. T. Matlock, William McAlphin, William Parker, Aaron 
Payne, Truman P. Powers; William Shaw, Benjamin Simpson, W. St. Clair, John

Thorp, E. L. Walters, and Ralph Wilcox (Speaker of the House). George L. Curry served as chief clerk of the Council, and Asahel Bush served as chief clerk of the House. $^{7}$

Member Characteristics of the 1850-1851 Legislative Assembly ${ }^{8}$

\begin{tabular}{|c|c|c|c|}
\hline 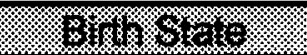 & (1) & Orceur.t. & W. \\
\hline Tennessee & 5 & Farmer & 16 \\
\hline New York & 4 & Merchant & 5 \\
\hline Pennsylvania & 4 & Lawyer & 4 \\
\hline Kentucky & 4 & Physician & 3 \\
\hline Connecticut & 2 & Surveyor & 2 \\
\hline Maryland & 2 & Carpenter & 1 \\
\hline Missouri & 1 & Mechanic & 1 \\
\hline Virginia & 1 & H & \%:. \\
\hline Vermont & 1 & Married & 18 \\
\hline 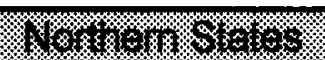 & 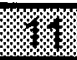 & Single & 3 \\
\hline 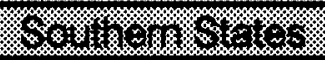 & 18 & Widowed & 3 \\
\hline \multicolumn{2}{|c|}{ (1) } & 17"1 & X \\
\hline 1843 & & members in their $20 \mathrm{~s}$ & 3 \\
\hline 1844 & & members in their $30 \mathrm{~s}$ & 5 \\
\hline 1845 & & members in their $40 \mathrm{~s}$ & 6 \\
\hline 1846 & & members in their $50 \mathrm{~s}$ & 9 \\
\hline 1847 & & members in their $60 \mathrm{~s}$ & 1 \\
\hline 1848 & & & \\
\hline 1849 & & & \\
\hline
\end{tabular}

7 "Members of the Legislative Assembly relating to the birth place, age, occupation, condition \&C of the members of the Legislative Assembly, recently in session in this city," The Oregon Statesman, March 28, 1851, p. 1." For further biographical information on individuals not given in this text, see Bancroft, History of Oregon, and Coming, Dictionary of Oregon History.

8 Ibid.

9 Some members had two occupations, for example, most members were farmers but some may also have been lawyers. 
For over one hundred years historians of Oregon, (from Hubert Bancroft in 1888 to Malcolm Clark more recently in 1981), have dealt with the location issue in much detail; however, they researched the issue by primarily examining it through the observations of Governor Gaines's adversaries. It is not the purpose here to redefine the location issue, but rather look at it from the viewpoint of Governor Gaines. ${ }^{10}$ According to his son Archibald, Gaines obtained a copy of the Location Act,

". . . examined it, and considering it so utterly defective in its provisions in addition to its entire unconstitutionality, and the impossibility of his conscientiously cooperating in its execution, sent the [Legislative Assembly] a respectful message, stating the reasons why he could not cooperate with them in executing the law, and at the same time iequesting, that, before they closed their session, they would pass a law that he could sanction, and cooperate with them in carrying out. ${ }^{11}$

Gaines considered the location bill invalid: it contained more than one subject and no provisions for the dissemination of funding provided for the institutions.

Moreover, the Governor felt the act to be,

". . . exceedingly defective in not adopting a plan of buildings, proportioning them to the amount of money on hand for those purposes, which was limited; and above all in not first informing themselves previously to any action upon the subject, by securing proportions from mechanics versed in such matters, based upon a plan selected, and commensurate with the amount of money appropriated by Congress for those purposes." ${ }^{12}$

\footnotetext{
${ }^{10}$ For further discussion of the location issue see Bancroft, History of Oregon, II, Chapter V, "Administration of Gaines," pp. 139-173; Carey, General History of Oregon, pp. 469-473; Clark, Eden Seekers, pp. 244-253, 255; and Robert W. Johannsen, Frontier Politics and the Sectional Conflict: The Pacific Northwest on the Eve of the Civil War (Seattle: University of Washington Press, 1955), p. 53. Clark's Eden Seekers comes the closest to looking at the Gaines era from a point of view other than the Salem Clique's.

${ }_{11}$ Archibald K. Gaines Joumal, March 10, 1852.

12 Ibid.
} 
In other words, Gaines thought the assembly should have requested an architectural bid for the design of the buildings. Moreover, he felt they should have thoroughly investigated the cost of construction by requesting bids from contractors showing the cost of labor and materials. The Location Act included a clause that provided for the appointment of commissioners to superintend their respective buildings (one each for the capitol, the penitentiary, and the university). Governor Gaines held the conviction that the clause regarding the commissioners should have been separate from that which located the Territorial institutions. Further, he felt the Assembly should have designed a separate piece of legislation for the costs and erection of the buildings themselves.

So, in essence, had the Legislature enacted three separate acts for each of the institutions, (i.e., a total of nine acts as follows: an act each for the location of the capitol, penitentiary, and university; three acts appointing and outlining the duties of the commissioners of the buildings; and three separate acts outlining the design and cost of construction for each institution), Gaines probably would have cooperated regarding the disbursement of funds. Reflecting his father's viewpoint, Archibald Gaines wrote,

"The Legislature took the whole business into their own hands regardless of any interest or authority the Gov[ernor] may have had in the matter, or any responsibility which may have rested upon him to see that the money was faithfully applied to the purposes for which it was intended, to the faithful disbursement of which he was held to a strict accountability by the department at Washington. . . The law, therefore, was defective in not providing for his concession as to the place for the location of the penitentiary, his cooperation in 
the disbursement of the funds . . . the safety of said funds, by the failure of security, not adopting a plan of said buildings instead of leaving to the discretion of said commissioners which must have been the case inevitably, in the absence of anything in the act upon the subject, and in not having their actions based upon, and everything commensurate with, the money on hand for those purposes." 13

Gaines sent the Location Act to United States Attorney, Amory Holbrook, for evaluation. When Holbrook agreed with Gaines upon the invalidity of the bill, the members of the Legislative Assembly became enraged. How dare the federal officers challenge the Assembly's authority. Oregon's Democratic Party coalesced when the members of the Clique unified their separate interests and focused against Governor Gaines and other federally appointed officials regarding the location of the territorial institutions. Gaines felt extreme disappointment with the individuals of the Legislature. All he had asked for was a little cooperation, a little reciprocity between himself and the assemblymen, but, ". . this they could not do, showing plainly that it was a log rolling business, and that they had been engaged in the very thing which the Organic Act intended should be avoided if possible, by that perticular portion of the law which says, to prevent improper influences \&c every law shall embrace but one subject. . ."

With this circumstance in mind Governor Gaines wrote to Attorney General John J. Crittenden on February 6, 1851, for advice on the location fiasco, enclosing with his letter a copy of the Act. Of course, the territorial press had a field day with the location issue. The Statesman would not let the matter rest until

${ }^{13}$ Ibid.

${ }^{14}$ Ibid. 
the Clique gained the omnipotent upper hand. The Oregonian, on the other hand, willingly printed the letters and messages of the Governor regarding the location issue. $^{15}$ In the August 2, 1851, issue of the Oregonian there appeared on the second page the correspondence from Gaines to Crittenden at Washington City. Gaines wrote,

"Sir: I . . ask the favor of you, at your earliest convenience, to furnish me with an official opinion, as to the validity of the Act in question; and especially whether the Legislative Assembly, can lawfully assemble at Salem, at its next session. Much difference of opinion exists amongst the members, and I am extremely anxious to have the question settled as early as possible."

\section{Apparently Daniel Webster forwarded Gaines's communication to}

Crittenden, who referred the matter to President Millard Fillmore. Fillmore sent it back to the Attorney General asking him to write an opinion. In his response to the President, Crittenden considered,

"1st, ... what purports to be an Act of the Legislative Assembly of the Territory of Oregon . . . 2nd, a message from Governor Gaines to that Assembly . . . expressing ... his dissent to that Act, and his refusal to participate in its execution ... and 3d (sic), an opinion of the United States Attorney for that Territory, given on the application of the Governor, against the validity of the said Act." ${ }^{17}$

Researching Congressional acts "relating to the subject," Crittenden cited "An Act to establish the Territorial Governmert of Oregon," created on August 14, 1848 , and "An Act to make further appropriations for public buildings in

\footnotetext{
15 Because so much has been written from the "Clique" point of view, I have chosen to show more of the other side of the story. For further reading from the Clique's viewpoint see issues of the Oregon Statesman, beginning on March 28, 1851 and continuing through 1855. There are sporadic comments thereafter as well, but not so heated in nature.

${ }^{16}$ Oregonian, August 2, 1851, p. 2.

17 lbid.
} 
Minnesota and Oregon," created June 11, 1850. Crittenden's opinion coincided

with that of the Governor on several instances; however, in one instance it

coincided with that of the Territorial Assembly. Crittenden opined,

"By the first of these acts, the Legislative power and authority are vested in the Legislative Assembly of the Territory, consisting of a Council and House of Representatives, and the concurrence or approval of the Governor is not requisite to the validity of their acts of Legislation. The power to 'locate and establish the seat of Government for said Territory at such place as they may deem eligible,' is expressly given to that Assembly by the 15th Section of that Act." ${ }^{\prime 18}$

Crittenden cautioned, however, that the Act of Congress, passed on June 11, 1850

". . . in its first section provides ... 'that the sum of twenty thousand dollars each, be, and the same is hereby, appropriated out of any money in the treasury not otherwise appropriated, to be applied by the Governors and Legislative Assemblies of the Territories of Minnesota and Oregon, at such place as they may select in said Territories for the erection of Penitentiaries;' and in the 3d (sic) section it further provides; 'that the sum of twenty thousand dollars \&c., be and the same is hereby appropriated \&c., to be applied by the Governor and Legislative Assembly of the Territory of Oregon, to the erection of suitable public buildings at the seat of Government of said Territory'..19

So, in essence, Crittenden's opinion was that the Legislative Assembly, by law,

had the right to select the location of the territorial capitol; however, Gaines had the authority, together with the Legislature, to disseminate funding for the construction of the public buildings. Crittenden, commenting further on the use of the money, said,

". . . they cannot dispose of it without the concurrence of the Governor. In regard

${ }^{18}$ Ibid.

${ }^{19}$ Ibid. 
to the first section of the act and the appropriation of twenty thousand dollars for the erection of the Penitentiary in Oregon, the act is too explicit to leave any room for construction. That money, in the words of the law, is to be applied "by the Governor or Legislative Assembly of Orezon at such place as they may select for the erection of a Penitentiary.' By force of this language, the Governor must have concurrent and equal power with the Assembly, not only in the application of the money to the erection of the necessary buildings, but in the selection of the place where they are to be erected." ${ }^{20}$

Concerning the other issues presented by Gaines in his communication,

Crittenden concurred with United States Attorney Holbrook. Moreover, he pointed out,

"The Act of Congress which established the Territorial Government of Oregon, and from which its Legislative Assembly derives its existence and its power, expressly and imperatively declares that, 'to avoid improper influences which may result from intermixing in one and the same Act, such things as have no proper relations to each other, every law shall embrace but one object, and that shall be expressed in the title.' That the act of the Legislative Assembly, in question, does 'embrace more than one object,' and that is, therefore, in violation of the Act of Congress, is a proposition that cannot be made plainer by argument. The same Act of Congress declares what shall be the consequence of such violation of its provision, namely, that Territorial Act, 'shall be utterly null and void.' My opinion, therefore of the Act in question is, that it is null and void in all parts, and, consequently can give no validity to any thing done under color of its authority."

Thus, in the words of Archibald Gaines, ". . the Governor was sustained thro out (sic)." ${ }^{22}$ The news from Washington buoyed the Governor's hopes that all would go well during the next legislative session; however, in December a majority of the Oregon Territorial Legislature opened its regular session at Salem which put a complete damper on the Governor's optimism. The act creating the

${ }^{20}$ Ibid.

${ }^{21}$ Ibid.

${ }^{22}$ Archibald K. Gaines Joumal, March 10, 1852. 
territory had mandated the legislature to select a seat of government at the first session or as soon as possible thereafter. In Governor Gaines's opinion, the Legislative Assembly had chosen Oregon City as the seat of government. Moreover, the Governor reasoned, Governor Lane and the legislative body confirmed Oregon City as the seat of government by virtue of that body meeting there for three successive sessions without declaring any other location as the seat of government. Therefore, the seat of government should remain at that location until the legislature approved a properly written act passed for that purpose. ${ }^{23}$ Refusing to recognize Salem as the seat of government, Governor Gaines attempted to hold a legislative session at Oregon City. Present was Territorial Secretary Edward Hamilton, Columbia Lancaster, William T. Matlock, R. C. Kinney, and Democrat Aaron E. Wait, but because they held no quorum they adjourned day by day.

The Territorial Supreme Court, consisting of Chief Justice Thomas Nelson and Justice William Strong, met in quorum at Oregon City. Judge Pratt had previously had the opportunity to become acquainted with Judge Nelson during his return trip to the Territory; however, probably because of Pratt's jealousy over Nelson's appointment as Chief Justice, it soon became apparent they would not get along. Pratt refused to work with Strong and Nelson, choosing instead to hold session in Salem and side with the Clique over the location issue. Elucidating on

23 Ibid. 
the situation facing the Territorial Supreme Court (Strong and Nelson) regarding the location issue, Archibald Gaines wrote,

"The sup[reme] court of the Territory are authorized, annually, to hold a session of court at the Seat of Gov[ernment] -- the question with them, was, where is that place. They examined all the law upon the subject to aid them in seeking that point . . . they find from a careful examination of the late and last law passed upon the subject that the Seat of Gov[ernment] is not, and cannot be at Salem under the law before them -- if such is the fact, any action on their part at that place would be null and void for the want of power to act . . . they are authorized to act at the Seat of Gov[ernment] and at no other place. . . Even if they believed the law locating the Seat of Gov[ernment] to he void, and would so pronounce it when brought before them, the very fact that they might have so pronounced it that place could have availed nothing from the fact that it was adjudicated upon at a place other than the seat of Gov[ernment] and at no other place than the Seat of Gov[ernment] could they legally act-- Therefore had they met at Salem in conformity to said act ... they could not legally act upon any question whatever. . "24

Thus Strong and Nelson concurred with the Governor in their opinion over the location issue.

There is some evidence that individuals, namely Pratt and Deady who now aligned themselves with the Democratic Clique in Salem, had previously considered the location bill void. Deady, as mentioned previously, originally voted against the bill, and while campaigning "for a seat on the council, argued stoutly that the law was void." ${ }^{25}$ Yet, on December 1, 1851, during the 1851-1852

\footnotetext{
24 Ibid.

${ }^{25}$ Clark, 249-250. Further commenting on the assemblyman's character at the time and that of his friend, Asahel Bush, Clark says, "Bush, who cared not a fig about legalisms, was so confounded by what he thought an irrational stand that he expressed a fear Deady would lose to his Whig opponent, David Logan, lately of Illinois. Logan was a masterful trial lawyer, a caustic speaker and an accomplished boozer. Deady got him drunk -- a state in which Logan sustained himself without appreciable aid through much of the campaign - and won handily."
} 
Legislative Session, Deady wrote to Lane at Washington City,

"You will and must see at a glance that some prompt action of Congress is demanded in reference to those judges who have thus refused to meet at the presumptive seat of government, where they by law were bound to meet . . I hope you will not involve yourself in the question of where the capital ought to be, by seeking a confirmation of this law from Congress."26

Lane's response shows his intention to malign Gaines and uphold the legislators in Salem:

"... The Representatives of the people are the only law making power known to the people of Oregon, as far as municipal enactments are concerned. The Acts of the Assembly, therefore, should be respected and sustained, not only by every citizen but by every civil and military officer in the Territory, and especially by one whose duty it is to see that the laws are faithfully executed, and who has no right or power to decide upon the validity or constitutionality of laws passed by the Assembly. I hate technical quibbles and evasions. To me it would have been enough to know that the assembly had located, by enactment, the seat of government, and so it should have been to any man, governor or other. The Assembly in my judgment acted correctly in holding their session at Salem." ${ }^{27}$

In a private conversation with Deady, Pratt had also agreed the law had problems; however, with political aspirations in mind Pratt later resolved to publicly condemn the Gaines administration on the issue -- probably at the suggestion of Asahel Bush after Holbrook sided with Gaines over the legality of the Location Act. ${ }^{28}$

Pratt had become "a busy partner in Bush's intrigues" and while holding court in Salem he developed a plan for further political disorder. The plan

\footnotetext{
${ }^{26}$ Correspondence from Mathew Deady to Joseph Lane as cited in Newton, p. 25.

${ }^{27}$ Correspondence from Joseph Lane to Mathew Deady, dated Washington City, February 19, 1852, as cited in Newton, p. 26.

${ }^{28}$ Clark, p. 251.
} 
concerned the lowa Statutes and whether the territory had adopted the rules compiled in 1839 or the version printed in 1843 as the laws of Oregon. ${ }^{29}$ The contrivance was absurd and obvious -- "Nelson and Strong opted for the former. Pratt, anxious to ingratiate himself with Oregon Democrats, plumped resolutely for the latter." ${ }^{30}$ Pratt's efforts produced the desired results though -- the political partisanship increased and so did the tension felt by Governor Gaines.

Realizing the group in Salem was not planning to adjourn Gaines and the others at Oregon City "finally adjourned Sine Die." Observing his father's humiliation while at the same time presenting an optimistic regard for the citizens of the Territory, Archibald Gaines wrote, "Judge Pratt with a few other leading Democrats determined to ride into power on the question, and are now endeavoring tn organize the Democratic party upon the question, pandering the prejudices which they suppose may exist against federal officers, crying out federal dictation, Gov[ernment] oppression, \&c, \&c -and for a while it seemed as if Democracy would swallow everything before it, but now the scale is rather changing, the people are beginning to awaken. ..."32

On January 9,1852 , Pratt read his opinion on the location issue to the Legislative Assembly condemning his colleagues on the bench for their opposing opinion in the process. ${ }^{33}$ John Pollard Gaines's son epitomized the Governor's frustration as he interpreted Pratt's opinions regarding the Act:

\footnotetext{
${ }^{29}$ See Coming, p. 30, and Clark, pp. 251-252, for a brief discussion of the lowa Statute controversy.

${ }^{30}$ Clark, p. 251.

${ }^{31}$ Archibald K. Gaines Joumal, March 10, 1852.

32 Ibid.

33 Ibid.; Charles H. Carey, "The Creation of Oregon as a State," Oregon Historical Quarterly, XXVI (December 1925), p. 286.
} 
"The Legislative Assembly having power conferred upon them . . may not have done ... precisely as the statutes point out, (which fact I do not understand him to admit however as he did at first, now taking the ground that [there] is but one object in the bill, and that the law is entirely valid, not even voidable as was his first position), still the act is good from the fact that [the Legislative Assembly] had jurisdiction over the subject matter, [and] that their action may probably come under the head of what is termed directory. ${ }^{.34}$

A directory statute was one over which the legislative body had jurisdiction and prescribed the manner in which a law passed. Further, according to Archibald Gaines, a directory statute stated,

". . . if the manner prescribed is not imperative or negative, but merely directory or affirmative in its nature, any action on [the Legislative Assembly's] part not in strict conformity to said directory obligation, would not thereby by validated, but if not in conformity to said imperative obligation, that . . it would be void. . . ."35

The Assembly sent Pratt's opinion to Congress together with a memorial from the Territorial Legislature declaring "that the majority judges had abused their high office in attempting to hold court at Oregon City or to decide the statute void." They also accused Nelson and Strong of "fulminating" against the Assembly,

". . . and of issuing paper decrees, characterizing the members as revolutionists and disorganizers. [They] expressed the opinion that public confidence in the judiciary department had been seriously impaired, and strongly intimated that the two judges were unfit for their high office.".36

Regarding the Governor, they cried,

"Ever since he landed upon our shores and entered upon the duties of the office, either from mental perverseness or, what is more probable, the mischievous

\footnotetext{
${ }^{34}$ Archibald K. Gaines Joumal, March 10, 1852

${ }^{35}$ Ibid.

${ }^{36}$ Carey, A General History of Oregon, p. 471.
} 
advice of the district attorney, Amory Holbrook, he has sought by indirect and extra official acts to usurp the powers placed in the hands of the representatives of the people alone, and the consequence has been that confusion and discord have, like the cloud that precedes the storm, overshadowed our public affairs." ${ }^{\text {"37 }}$

Reaction to the Act varied throughout the territory. Of course, the

Governor considered the one-subject clause in the Organic Act proof

"conclusively to the mind of every unprejudiced man" that the Location Act was

entirely unconstitutional; however, he opined to his son,

"[T]here are those in the territory who conceive it to be valid upon the ground that the three objects as contained in the act are but one, to wit, the public buildings of the Territory ... There are others in the territory who take the ground that tho (sic) the law may be unconstitutional, it is merely at the same time a voidable law, and should be enforced until adjudicated upon by the courts. . . Another party in the territory and by far the most numerous at this time, as is supposed assumes that the law is void abeinto, that it never had any binding force upon any one from the time of its passage, and upon the ground that they were directly prohibited from passing a law upon any subject having more than one object, and think it the duty of every citizen to resist the execution of such law. . ." ${ }^{38}$

The last comment above alludes to Pratt's opinion. The Governor maintained that Pratt misinterpreted the Organic Act deliberately to gain grace with the opposition. Further, the Governor reasoned,

". . . upon the ground that Judge Pratt is right in assuming the position, that any law passed, over which [the Legislative Assembly has] no jurisdiction, is void, abeinto, there the law under discussion falls to the ground from [Pratt's] own showing, which is also strengthened by that portion of the Organic

Law which says that all laws passed inconsistent with the Organic Law, and therefore utterly null and void, is a question to simple to be argued. ..." ${ }^{\text {"39 }}$

\footnotetext{
37 Ibid., p. 472.

38 Archibald K. Gaines Joumal, March 10, 1852.

${ }^{39}$ Carey, p. 473.
} 
The memorial from the Legislative Assembly received attention in Congress and with the careful guidance of Lane (now acting as the Territory's delegate in Congress) the Act establishing the Territorial capital at Salem became law on May 4, 1852. Not only did Congress declare Salem the Territory's legal seat of government, but it also found valid all the laws adopted by the Legislature while at that location. Responding to a letter written by a shocked Amory Hobrook, President Fillmore on July 26, 1852, wrote,

"I did not scrutinize the resolution when presented to me for my approval . . .I supposed it was intended merely to legalize the proceedings of the legislative assembly at Salem, but not to express any opinion whether they were legal or illegal under the organic law. On that point the attorney general had given his opinion, in which I fully concurred then and do now, and the very fact that this joint resolution was passed was an evidence, at least, that these proceedings were not considered as valid without being ratified by [C]ongress. There may have been some artful design in the wording of the resolution, intending to give it a local effect in Oregon, of which I was wholly unaware. I regret, however, that anything should have transpired that should have led anyone to suppose for a moment that I had changed my opinion in reference to the true construction of the organic law." ${ }^{, 0}$

Nonetheless, Governor Gaines, even though legally and constitutionally correct in his opinion on the omnibus bill, became disgraced through the actions of individuals seeking to destroy his authority, and never completely recovered politically.

The Governor and his family held their heads high through this very trying political situation, continuing on with their personal lives. On August 10, 1851,

40 Ibid. 
Governor Gaines departed Oregon City with his fifty-one-year-old wife, Elizabeth; and his daughters, twenty-four-year-old Anna Maria; twelve-year-old Mary Elizabeth (called Mary); and ten-year-old Matilda (called Tilly), to see their new home on the Clatsop Plains. The family left young Abner, now sixteen-years-old, in charge of their home at Oregon City. It had been nearly a year since their arrival in the territory, during which time the family had been renting a house in Oregon City and had "passed through some remarkable scenes." During their stay in the Territory thus far the family had become acquainted with the "people, manners, [and] customs of the country." They made a few friends, but no strong friendships. ${ }^{41}$

Governor Gaines bought a farm on the Clatsop Plains in March of 1851 and his twenty-seven-year-old son, Archibald, remained there improving the land in anticipation of the family's arrival. Boarding the steamer Willamette near Portland, the family cruised down the Columbia River to Astoria. There they dropped off Anna Maria at General John Adair's home, picked up General Adair's son and daughter, John and Kate, and boarded an open boat. They crossed Young's Bay, and, leaving the bay, they floated a mile and a half up a little creek to a place known as Lexington. They disembarked at Skipanown Landing which stood about eight miles from Astoria. ${ }^{42}$

\footnotetext{
41 Archibald K. Gaines Journal. This entry is dated Clatsop Plains, August 22, 1851.

42 "Died," Oregon Spectator, August 19, 1851, p. 2.
} 
While at Lexington John and Elizabeth enjoyed a leisurely Sunday afternoon dinner. Mary, Tilly, John, and Kate continued on for three more miles on horseback to the family's new farm. The four young people arrived around 2:30 where they found Archibald sitting 0.7 the open porch of the partially painted farm house. Over the course of the next few hours they visited and the girls prepared an excellent dinner that they ate while waiting for the arrival of John and Elizabeth. Archibald wrote that the girls were "even anticipating much pleasure on the [P]lains [and] seemed to be delighted with every thing around them." Then, at about four o'clock, a messenger rode up to the farm house bringing tragic news about Elizabeth Gaines which "at once blasted [away] all their anticipated pleasure." 43 John and Elizabeth left Lexington after having eaten dinner there. Elizabeth mounted a very gentle and trusted horse and John mounted another horse -- both horses belonging to a Colonel Taylor. About one mile down the road toward the farm they met some people traveling from church services in an ox-drawn wagon. Acknowledging them as acquaintances, John and Elizabeth stopped and began a conversation. Then, at approximately 3:30, Elizabeth "met with a sad and melancholy accident. . . ."44

Upon hearing the news, Archibald immediately mounted his horse and headed toward the scene of the accident. Finding that the Governor had moved

\footnotetext{
${ }_{44}^{43}$ Archibald K. Gaines Joumal, Clatsop Plains, August 22, 1851.
}

${ }^{44}$ Ibid. 
his wife to the Wirt farm near Lexington Archibald rode quickly to that location.

Elizabeth's "life was despaired of . . . the indications of death were indeed too plain to admit of doubt," wrote Archibald. He continues, "I never shall forget my feelings when I first beheld my Mother lying upon the bed at Mr. Wirt's. ..." After visiting his mother's bedside and finding her incognizant, Archibald turned to his father who relayed the details of the accident:

". . . Mother's horse backed between the fore part of the waggon (sic) and the oxen at the same time touching the ox, this seemed to alarm him very much, he darted in an instant carrying the horse with my Mother upon him in front of the fore wheel for some little distance; she finally fell back from the horse on the tongue of the waggon (sic); striking a severe blow upon her head. . . "45

Further details of the accident appeared in the Oregon Spectator a few days later:

"Mrs. Gaines fell, her head striking the tyre of the wagon, and her body being jammed between the front board and the horse. The horse being thrown down, was passed over by the wheels of the wagon, and Mrs. Gaines fell underneath, before the oxen were checked." ${ }^{\prime 46}$

The fall caused extensive bleeding and a brain concussion, resulting in unconsciousness almost immediately. Governor Gaines told Archibald that Elizabeth "spoke but one sentence after the accident, which was, I am almost gone; this immediately followed the accident: her speech and mind immediately left her." ${ }^{47}$ Gaines sent for a physician who made every effort to save her life.

Ann Maria, summoned immediately after the accident, arrived that evening

\footnotetext{
${ }^{45}$ Ibid.

46 "Died," Oregon Spectator, August 19, 1851, p. 2.

47 Ibid.
} 
around ten. Archibald returned to the farm and brought the two young girls back with him. ${ }^{48}$ Elizabeth remained unconscious for a little over three days, then about five in the evening of Wednesday, August $13,1851, " \ldots$ her spirit took its flight into heaven." A grieving Archibald wrote, "Her death was an easy one, without a struggle... what a scene for our family- oh what a loss it may prove to my dear little sisters, Mary \& Tilly."

A service for Elizabeth took place at noon on August 15. Ironically, Archibald noted,

"At the time almost precisely at which she expired 12 months previously we reached the bar out side the Columbia [R]iver and anchored our ship, the sloop of war [F]almouth. . . [S] he was interred at 10 oclock (sic) in a beautiful spot near the Presbyterian church, and in a beautiful section of Country called [C]latsop [P]lains, about one mile from our farm, facing . . the . . . [P]acific about one mile distant from it. . . . The Plains . . are about 20 miles in length from north to south running with the Pacific Ocean, and about one mile in width from the ocean back east $\&$ west ... This is a most beautiful section of country, made entirely from the ocean, thrown up in regular, and beautiful ridges and valleys. . . There is at all times a continual sound from the ebbing and flowing, of the tide, yet she hears it not on this Earth, that she hears it from above, and looks down upon her beautiful burial spot, I sincerely hope. At the precise time at which she was buried . . . one year previously, we reached the post of Astoria, after a long and arduous trip from the City of N[ew] York around Cape Horn of $71 / 2$ months: a most remarkable coincidence. ... Our voyage to Oregon seems to be one continued disaster, after another. May a better fate yet await us. ${ }^{49}$

After Elizabeth's death, Governor Gaines sold his farm on the Clatsop

Plains to the man from whom he had purchased it, John Hoblson. By August 28,

\footnotetext{
48 Archibald K. Gaines Joumal, Clatsop Plains, August 22, 1851. I can only assume that someone sent for Abner. Archibald does not mention him arriving before his mother's death or for her funeral.

49 Ibid.
} 
1851 , he had in hand about $\$ 4,500$ from the sale, and expected $\$ 1,250$ more on March 1, 1852. In early October his daughters, Anna, Mary, and Tilly, and his youngest son, Abner, began making preparations for a return trip to Kentucky. They departed Oregon City on Wednesday, October $8,1851 .^{50}$ Instead of traveling the long journey around Cape Horn the children traveled across the Isthmus of Panama, arriving in New Orleans on November 20, 1851. They experienced some sickness along the way but nothing when compared to the trip to the Oregon Territory fourteen months earlier. From New Orleans the children traveled to Arkansas and Kentucky, where they remained in the care of relatives. $^{51}$

Despite the political setbacks and another tragic loss in his family, Governor Gaines remained in the Oregon Territory. Letters to the editor of the Oregonian showed a high regard for Gaines during and after the location issue became a hotly debated item. One letter, dated August 1,1851 , regarding the location issue, states,

"Let the Legislature conform to the laws of the general government in this matter, and the majority will, or at least ought to be, satisfied, let the locations be where they may be. It is a revolutionary principle to suppose the that the Legislature here have the power to pass and enforce laws on the Governor or the governed which are in direct violation of the constitution and special acts of Congress. I would respectfully ask Mr. D[avidson] to look at the oath of office taken by the Governor, and say, if situated thus, whether he would have acted differently. . I I glory in his [Gaines] spunk and in the spunk of all such, be they [W] hig or

\footnotetext{
${ }^{50} \mathrm{Ibid}$. Journal entry is dated October 2,1851 , but mentions events after that date.

${ }^{51}$ Ibid.
} 
[D]emocrat." ${ }^{52}$

In the Oregon Statesman, Bush continued to attack the Governor's stand on the location issue. Moreover, he had launched a campaign to viciously and continuously attack the Governor's character day after day. The Oregon Spectator reacted to one attack upon the character of Governor Gaines regarding the manner in which he and his family arrived in the Oregon Territory. The Statesman had compared Gaines's mode of travel to Lane's:

"... [T]he editor of the Statesman adopts the declaration that Gen. Lane came to the Territory overland 'in the garb of a western man with a small company of men, with a rifle in his hand at his own expense an exile from his family.' While Gen[eral] (sic) Gaines came 'out at the Government expense in a Government vessel'.,"53

\section{The Spectator responded:}

"Gen[eral] Lane did not come out [an exile from his family] -- his son came with him to California and went into the mines to dig gold. Gov[ernor] Lane did not come hither at his own expense. He came under an escort of twenty-five soldiers commanded by an officer of the United States army . . Gov[ernor] Gaines . . . had permission to embark himself and family on a ship sent with supplies to the Pacific coast - a ship whose destination and the expense of whose voyage was not in any manner affected by the transportation of Gov[ernor] Gaines. . . . He paid for his traveling expenses as much, if not more, on the public vessel as he would have been required to pay on a merchant vessel. He came, in his own emphatic language to become a citizen of Oregon. Embarked his fortunes and his family--and truly 'burnt his ships behind him.' He gave the strongest pledges

\footnotetext{
52 "Seat of Govemment," Oregonian, August 9, 1851, p.2. The Mr. Davidson referred to in the letter is an assemblyman from Marion County; however, I have been unable to ascertain his first name. This letter is signed "Plow Boy." It is possible "Plow Boy" is A. R. Stroughton. His name appears at the bottom of an advertisement in the Oregon Statesman titled "Plow Boy," dated Salem, April 28, 1855. Plow Boy appears to be a reference to a horse. The advertisement describes him as "a four year old, dappled brown, over sixteen hands high . . . sired by 'Old George.' He comprises the best blond for both the road and the farm, of any horse on the Pacific Coast. ..."

53 "The Administration and the Removal of Gov. Lane," Oregon Spectator, April 10, 1851, p. 1.
} 
known to men--all his pecuniary wealth, and that wealth which none but a father can truly estimate, his family. . . . Can Oregon ever repay him the sacrifice of those 'dear ones' who fell by the wayside on their journey hither?"54

The Spectator closes the article with a question and answer:

"And how does the character of the two men, presented for the public judgment in their conduct here, contrast? What has Gov[ernor] Lane done here? With what recollections or with what interests is the public mind of Oregon familiar? No breath of imputation reaches the conduct of Gov[ernor] Gaines regarding the sacrifice of public interest to private purposes. We impute no neglect on to Gen[eral] Lane, but we demand that a just statement of facts shall be presented to the people, if the decision of the people is to be invoked as to the conduct and character of the late and present Executive of Oregon." ${ }^{.55}$

Responding to the Spectator's representation, the Statesman repeated its argument that Gaines came to Oregon at the expense of the Federal Government while all Lane "received from [the] Government was the use of one wagon." In hindsight, one can make the argument that in both instances the governors traveled in a manner suiting their purpose. Governor Lane traveled overland bringing with him United States Marshall Joe Meek and soldiers sent to protect the Oregon Territory. Governor Gaines traveled in a government supply ship -- a ship whose destination was San Francisco before Gaines ever thought of boarding it, and on board which Gaines brought the Oregon Territory's library. The two governors took just about as long to reach Oregon: Lane, traveling overland, took a little over six months; Gaines, traveling around Cape Horn and at

\footnotetext{
54 Ibid.

55 Ibid. The article is signed JUSTICE.

56 Oregon Statesman, April 18, 1851, p.2.
} 
the mercy of the ship's captain, took seven-and-a-half months to get from New York to the Oregon Territory. One should remember that although Gaines received his appointment in October, he opted to sell his property in Kentucky and commit himself and his family to a new life in Oregon. He also visited Washington City for instructions and purchased supplies for the Territory in New York. Further, there is evidence showing Gaines paid for groceries and other merchandise besides the books for Oregon's library, including household furniture, sewing supplies, and farm equipment while in New York waiting for the ship Supply to depart that city. ${ }^{57}$ There was no possible way for Gaines to bring the Territorial Library and his household furniture overland to Oregon. Had Lane's purpose been to sell his property, pack up his family and their belongings to accompany him, and visit with President Polk directly for instructions before his departure for the West, he probably would have taken just as long, if not longer, to reach the Territory.

News of Governor Gaines and his controversies in the Oregon Territory spread throughout the United States. Even newspapers on the East Coast began printing articles about the governor who challenged the Oregon Territorial Legislature. The Oregonian reprinted a letter, "written by a distinguished gentleman of [the Democratic party], who knows well what he talks about, and

${ }^{57}$ See Gaines Papers, reel 4, box 7, folder 2, beginning at frame 00043 . This folder holds the accounts and receipts of the expenses incurred from December 1849 through January 1850 during Govemor Gaines's joumey to Oregon beginning in New York City, New York. 
has the manliness to tell what he knows," to the editor of the Boston Post.

"I have had the pleasure of reading your spirited and valuable paper . . . in which under the head of Oregon, the character of Gov[ernor] Gaines . . . is reflected upon. Now, though one 'after the strictest sect' of democracy, I deem it one of the duties imposed by that creed, not to allow injurious impressions to be spread abroad, even against an enemy, without refutation. . . . I know from personal knowledge, that Gen[eral] (sic) Gaines has sacrificed more for Oregon, than the whole tribe of his defamers there, legislators and caballers, put together. $\mathrm{He}$ embarked his all, his family and estates, in the fortunes of the territory. . . When he went to Oregon therefore, he carried with him his household goods--bore in his hands his most sacred pledges of society--'burnt his ships behind him' and gave all he had, and all he was to her people." ${ }^{58}$

Commenting on the location issue the writer said,

"An effort of the legislature to exclude him from the exercise of an authority and the performance of a duty, imposed upon him equally with themselves, by an act of Congress ... has given occasion to interested defamation of his character, that which, nothing can be more grossly unjust; and if the facts bore company with the slanders, they would themselves refute it. Every man who has had an opportunity of observing the bitterness and injustice, engendered in the struggle for ascendancy, in a territory which is looking for speedy admission into the Union, will recognize the dominant feature of policy, of little local politicians, to make the existing authorities as odious as possible to the people with a view to excite their eagerness for an independent organization. ${ }^{.59}$

Elucidating upon Oregon's political nature, the gentleman continued,

"There is no doubt that Oregon is democratic; but if the democracy congratulate themselves in having obtained their representative in [C]ongress, by the election of Gen[eral] Lane as their delegate, they owe their thanks to Gov[ernor] Gaines, who threw his entire influence, personal and political, in his behalf. Gen[eral] Lane professed to run as an independent candidate, irrespective of politics, and received the whole vote of the [W] hig party. . .,"60

The Democrat closed his letter with further comment upon Gaines's character:

\footnotetext{
58 Oregonian, March 23, 1853, p. 2.

59 Ibid.

60 Ibid.
} 
"I must earnestly maintain--waiving politics--that a more highminded, honorable and gallant gentleman does not exist; nor an executive officer, either by commission or election, more faithfully, honestly and usefully devoted to the people over whom he presides, than Gov[ernor] John P. Gaines, of Oregon."161

Gaines understood the desire of local citizens to have individuals from the Territory serve as public officers. In a letter to the Secretary of the Interior at Washington City, dated Oregon City, March 8, 1852, Gaines addressed this subject most admirably:

"Sir;

In the supposition that land offices will be established in this Territory with a [vein] of dispensing of land which may not be taken up under what is called the donation law, I . . recommend for the office of Register Receiver W. D. S.

Schnibly of Lynn City- W. S. has been some two years a citizen of the Territory, has a family and is in every way identified with our interest, and would . . make an excellent officer -- I would earnestly recommend that in every case, citizens of the Territory should have the preference when competent persons can be had-It [creates] confidence between officer \& citizen and all business is transacted much more harmoniously than when nonresidents are sent."162

Gaines's son, Archibald, left for the States in early March of 1852, before news of the Congressional action regarding the location issue arrived in Oregon. Notwithstanding the departure of his eldest son -- the last member of his family in the Territory - and his political difficulties, Governor Gaines determined to continue in the Territory. In July of 1852, with the opinion that the public building issue needed additional attention, the Governor called a special session of the

\footnotetext{
${ }^{61}$ Ibid.

62 Letter to the Honorable A. H. Stuart, Secretary in Washington, from Govemor John Pollard Gaines, March 8, 1852, Oregon Historical Society Mss 683, F3 5. Incidentally, this letter was found among the Joseph Lane papers and is now in the John Pollard Gaines Manuscript Collection at the Oregon Historical Society.
} 
Oregon Territorial Legislature. ${ }^{63}$ In his message Gaines first congratulated the

Assembly:

"It is a subject of congratulation that the question of the seat of government, upon which for some time past there has been an animated conflict of opinion not only between the authorities but between the citizens of the Territory, has been determined by a tribunal whose authoritative voice no one will presume to disobey; and it is my ardent and sincere hope and I doubt not it is also that of every good citizen, that hereafter when questions may arise to disturb energetic and harmonious [productivity] that by working together for the common good, we may [attempt to] develop the affluent resources of the fertile vallies (sic) and coasts of Oregon. It now becomes our imperative duty, as it is our true interest, to carry out in good faith, the provisions of the law upon the subject of our public buildings, and to make use of all the legitimate means with our power for their speedy erection." ${ }^{64}$

Gaines continued by discussing the acts of Congress creating the Oregon

Territory and subsequent acts appropriating funds for the public buildings. He

then declared,

"The sum of twenty five thousand dollars has thus been granted by the United States for the erection of public buildings at the seat of government, and twenty thousand dollars for the erection of a penitentiary. No part of this money has as yet been expended. It has been in idle since its appropriation and has been of no service whatever. . . further action by the Legislature is necessary in order to supply the defects in the acts. No site was designated in the act upon which to erect the buildings at the seat of government, and no provision ever made by law for the selection and purchase thereat." ${ }^{\prime 65}$

\footnotetext{
${ }^{63}$ See Gaines Papers, reel 4, folder 7, frame 00239-00256. Documents on these frames appear to be Gaines notes and drafts of his address to the Legislative Assembly. The final address appears to have been prepared by a secretary, as it is not Gaines's handwriting. Because of fire and water damage to these documents, I have used both Gaines's notes and the version in other handwriting, to reconstruct the address as he would have read it.

64 Ibid

65 Ibid.
} 
Alluding to the selection of a board commissioners to supervise the construction

of the public buildings, Gaines continued his address suggesting,

". . . that the act gives no authority to any of the commissioners to draw money from the several sums appropriated by Congress, for the object referred to, nor does it in any way limit the amount to be expended under their direction. I recommend therefore, that provision be made by law for the selection and purchase of ground at the seat of government, and for clearing up all ambiguities in which the subject may at present be involved, so that all officers charged with the execution of any trust under said Location Act may attend to their duties and carry out the provisions of the law according to the true intent and meaning thereof." ${ }^{\prime 66}$

Gaines also addressed the Oregon Territory's judicial districts during the

special session. Concerned about fairness and equality in the dissemination of

justice, he suggested the district boundaries be redrawn:

"The rearrangement of the judicial districts is another matter to which your attention is invited. The rapid increase of population in the southern and also in the north part of the territory requires that provision be made for the administration of law at, such points as shall be convenient to the people. At present in the whole region south of the Calapooya Mountains Umpqua County is the only place in which District Courts are authorized to be held. This cannot fail to produce serious inconvenience -- subject to unnecessary expense many who for any cause are obliged to attend court I now come therefore to the Legislative Assembly to lay out anew the judicial districts in such way as will best comport with the true interest of the people in the various sections of the country and, in as much, as by reason of absence, sickness or inability, the proper judge of the district may fail to attend and hold his courts, I recommend also that some general law be passed authorizing, in such cases, one of the judges of other districts to supply his place, so as to prevent a failure of courts." ${ }^{.67}$

66 Ibid.

67 lbid. 
Commenting on the subject of Thurston County, created north of the Columbia River during the 1851-1852 session of the Assembly held in Salem, Gaines declared,

". . . that by an oversight no provision was made for holding courts in [Thurston County], or for annexing it to any other county for judicial purposes, nor was it organized except by the title of the act. A recent brief visit to that admirable portion of the Territory now rapidly filling up with an active and intelligent population, satisfied me that immediate steps should be taken to secure to such community the right of protection by laws in their various avocations. Especially as numerous Indian tribes reside within the limits of the country, and a revenue district of the United States is embraced in it, where important commercial questions may require prompt adjudication. ${ }^{.68}$

Continuing on a similar subject, Gaines remarked,

"Nothing is more important to the people than to have a complete system of laws adapted to the present condition and future developments of the country. Complaints are made against the present statutes as being in many instances incongruous with each other and so uncertain, so defective, and so unsuitable as to fail to meet the just wants of the people. . . By the act of organization, Congress adopted the laws of the Provisional Government with certain exceptions. The Provisional Government in its day, adopted the laws of lowa, so far as they were applicable. Since that time the Territorial Legislatures have passed numerous acts of the efficacy of several of which there exists much diversity of opinion. Many of the laws now in force and which had their origin in the days of the Provisional Government have never been printed. The doubt and obscurity which this [has] over many laws regulating the rights and duties of the citizens must in the nature of things produce frequent disputes and lead to litigation between the inhabitants, if not the consequences still more serious and deplorable. The delays that necessarily attend the administration of justice which the present laws themselves create is another reason why some new legislative action should be taken on the subject. . . Unless such means be furnished, the substantiated and permanent citizens of the country are liable to be at the mercy of every unprincipled adventurer who by art or fraud has induced them to permit property to be reduced into his possession." ${ }^{69}$

\footnotetext{
68 Ibid.

69 Ibid.
} 
Gaines went on to recommend a board of commissioners be appointed to revise

the Territorial laws. He suggested they report on the subject at the next regular

session of the Legislature. He also acknowledged that the project would be time

consuming and require much research. With this in mind he suggested,

"After the revisers make the report the Legislature could take such action upon the laws . . . as in their wisdom they might think proper: enacting them as reported, or modifying them in some respects, or changing them altogether. This seems to be the only practical or effectual mode of relieving the country from its present embarrassments. It is the course which most, if not all the old states and other territories have from time to time adopted, in order to accomplish a needed reform in their systems. The present Legislature cannot, in my judgment build for themselves a nobler monument, nor win a more profound and lasting gratitude from their fellow citizens, nor accomplish an object more beneficial to themselves than [the enactment] of a complete and ivholesome system of laws, suited to the condition of a great agricultural, mining, and commercial people such as now are beginning and are destined soon to be."70

In closing his address, the Governor mentioned that he knew of other issues for the Legislature to discuss; however, he believed these issues could wait until the next regular session. Commending the Assembly on convening during a time other than their normal session, Gaines noted,

"You have been assembled at a period of the year, when your private avocations most require your attentions. It was therefore with reluctance that l exercised the power of convoking you. Nothing but a deep sense of the importance of immediate legislative action would have induced me to take a step which would subject you to any personal inconvenience. I entertain, however, too high an opinion of your patriotic feeling to suppose that you would be unwilling to make any reasonable sacrifices of your private interests, for the sake of advancing the general good. I tender to you assurances of my strong desire to cooperate cordially with you in all measures that will provoke the good of the people, and advance the interest and character of our growing territory. Confidently relying upon your disposition to discharge with fidelity the duties of the honorable trust

70 Ibid. 
which has been committed into your hands by the people whom you represent, I invoke upon you deliberations the blessings of that benignant Providence who has as so many signal manifestations of his favor." ${ }^{71}$

Essentially ignoring the Governor, the legislature adjourned without considering any of the issues raised in Gaines's address. In December of 1852 the Legislative Assembly convened for their regular session. The Governor delivered a message to the Assembly, again calling attention to the immediate need for the construction of a penitentiary. He also "urged the improvement of the western end of the immigrant route, in view of the hardships suffered by incoming settlers ... recommended the passage of a law to provide for commissioners to take acknowledgments of deeds ... reviewed the resources of the territory and urged that home industry be stimulated whenever possible," and asserted his views regarding the location and sale of liquor. ${ }^{72}$ The Governor said, "If these establishments may be regarded as public benefits, the amount exacted for a license seems to be exorbitantly high; if, on the contrary, they are justly considered as unmixed evils, the tax should be greatly augmented, or by adequate enactments they should be prohibited altogether'."73

Again, the Legislative Assembly refused to acknowledge the Governor on any issues whatsoever. The Assembly did not request Gaines to address them -technically they only asked him for a report on the state of affairs in the Territory. Therefore, while they did, at least, listen to his message, they refused to take any

\footnotetext{
${ }^{71}$ Ibid.

${ }^{72}$ Carey, p. 474

${ }^{73}$ Ibid.
} 
action regarding the issues therein, choosing instead to postponed consideration of the issues indefinitely "on the ground that there was no connection between the legislative and executive departments of the territory. ${ }^{174}$

Despite this grandstanding gesture against the Governor, in January 1853 the Legislature finally passed some revised acts regarding the location and construction of the Territory's public buildings. One act, titled, "An Act, supplementary to an Act entitled 'An Act to provide for the selection of places for the location and erection of Public Buildings of the Ternitory of Oregon'," dealt specifically with the construction of the Oregon Territorial Penitentiary. It passed the House on January 10 and the Council on January 28,1853 . Consisting of twelve sections, the Act created "a board of commissioners for the construction of a Penitentiary." ${ }^{75}$ Not only did the Act require the Commissioners to take an oath in support of the United States Constitution, it also required them to ". . . enter into a bond with the Governor of the Territory, with two or more good and sufficient sureties to be approved by said Governor, in the sum of two thousand dollars, conditioned for the faithful performance of his duties according to law, which oath and bond shall be filed with the office of the Secretary of the Territory." ${ }^{76}$

Section five of the Act proclaimed the Governor,

"Treasurer of the fund appropriated by the Congress of the United States, to be applied to the erection of a Penitentiary; and when so directed by the board, to demand and receive from the proper officer of the United Sates Treasury, any and all moneys that now are, or may hereafter be appropriated for the erection of

\footnotetext{
${ }^{74}$ Ibid.

75 General Laws, (Salem, Oregon: Asahel Bush, Territorial Printer, 1854), p. 31.

76 Ibid., p. 32.
} 
a Penitentiary, and to keep the same in safety, being at all times prepared to pay the drafts of the board, out of such funds as he shall receive by virtue of the provisions of this act. ..."

Moreover, section six declared,

"No money shall be paid by the Treasurer for any purpose, unless on a draft ordered by the board and signed by the presiding commissioner, when so ordered and attested by the secretary of the board; and the board shall, in no case, sanction the payment of any money, unless the labor has been performed or the materials have been furnished in accordance with a contract entered into under the provisions of this act. ..."78

Section eight covered "necessary steps ... and measures ... to procure a suitable site upon which to erect [the] Penitentiary within the city limits of Portland." This section also specified the materials, namely brick or stone, to be used in the construction of the building.

Another act, titled, "An Act, to amend an act to provide for the select of places for location and erection of the Public Buildings of the Territory of Oregon," passed the Council on January 21 and the House on January 23, 1853. This act dealt with appointing commissioners, receiving proposals and letting contracts, and repealing certain sections of the former act of the same title. Moreover, it provided specifically for the construction of public buildings at the seat of the government in the Territory of Oregon. Section three provided for the Governor as Treasurer of the fund for the public buildings appropriated by Congress. It also required the Governor to "annually report to the Legislative Assembly the

\footnotetext{
77 Ibid.

78 Ibid., p. 33.
} 
amount of money so paid." ${ }^{, 9}$

So, finally after over two years the construction of the capital building at Salem and the penitentiary at Portland could finally begin; however, actual construction did not commence until after Gaines's term as governor expired. An act for the university at Corvallis did not pass until after Gaines left the office of governor. Notwithstanding his struggles with the Legislative Assembly during the location war Governor Gaines persevered and accomplished several deeds forgotten until now.

${ }^{79}$ Ibid., p. 46. 


\section{Chapter Eight}

\section{FORGOTTEN DEEDS}

"As parents, as citizens, as lovers of our race, we cannot but be keenly alive to anything that tends to diffuse the light of knowledge in our midst. If we wish to transmit to our children an inheritance that will be worth possessing, we can succeed in no better way, than to import to them the benefits of intellectual and moral culture. If we wish to exalt our territory to the highest pinnacle of greatness she is capable of attaining we must make her as conspicuous for the intelligence of her population as she is eminent for physical wealth and resources..."

At Albany, New York, in January of 1851, a woman named Margaret Wands received a letter of acceptance as a teacher for the Oregon Territory.

A year and a half earlier Governor Joseph Lane composed a letter to Governor William Slade of Vermont inquiring about obtaining teachers for Oregon. He wrote,

"I have read with interest, your first annual report on National Popular Education. There is no portion of our country where teachers are more needed, than in Oregon. . . I I see by your report, that teachers have been sent out to various portions of the West, and are doing great good. Can you not send some to Oregon?"2

Slade responded to Lane several months later, saying he would make an effort to "find ladies of the proper qualifications."3

Besides Miss Margaret Wands, several other individuals accepted appointments as Oregon teachers that year, including Miss Sarah Smith and

1 Gaines Papers, reel 4, box 7, folder 7, frame 00254 .

2 Ibid., reel 1, box 1, folder 2, frame 00054. Letter written by Governor Joseph Lane to Governor William Slade of Vermont, July 31, 1849. Lane's letter concludes, "Money is plenty, and the people are willing to pay any price for the education of their children. The Rev. George $H$. Atkinson and others have written you fully on this interesting subject, with the view of calling your attention to the condition of this beautiful, and at present, on the subject of education, suffering country."

3 Letter from Governor Slade to Joseph Lane, dated October 21, 1849, as cited in Carey, p. 706. 
Miss Elizabeth Millar also of New York, Miss Elizabeth Lincoln of Maine, and Miss Mary Gray of Vermont. In a February 1851 letter to Miss Wands, Governor Slade remarked,

"I have engaged a passage for the Oregon teachers in a steam ship of Howland P. Aspinwall line, which will leave N[ew] York on the 13th of March. I wish to have all the teachers in New York as early as the 11th. When you arrive, you will take a hack to Taylor's Temperance House, 28 Courtland Street, where you will find me."

Meanwhile in the Oregon Territory, citizens occupied themselves with starting schools for the education of their children. The question of organizing a public school met with affirmative action, but because of costs the settlers found starting an institution of education difficult. One group opted for a private operation and called it the Clackamas County Female Seminary. Prominent citizens, such as former Provisional Governor George Abernethy and Doctor John McLoughlin donated $\$ 1,500$ and a "block of land" respectively, helping the project get off to a good start. ${ }^{5}$ It was at this school that the five new teachers began instructing the female children of the Oregon Territory.

At the same time on the East Coast, the five teachers arrived in New York where they met Slade at Taylor's Temperance House as instructed. From there they embarked on the steamer that took them to the Isthmus of Panama. Interestingly, it was the same vessel that carried Oregon's Territorial Delegate, Samuel Thurston, who would pass away before reaching

4 Gaines Papers, reel 1, box 1, folder 2, frame 00060. Letter from William Slade to Margaret Wands, dated Middlebury, Vermont, February 19, 1851.

5 Carey, pp. 706-707; Bancroft, p. 136. 
Oregon. Upon their departure Governor Slade gave the teachers some final instructions:

"I desire to have it distinctly understood [by] all our teachers that we expect them to continue to teach at least two years should health permit. There have been a very few [cases] in which our teachers have married [within] the two years--a few of them . . . within three months. . I have required, in the latter cases . . . refunding of the amount expended [to bring] out the teachers, yet that has not [corrected] the unfavorable impression that [these] marriages have produced... It has from the beginning of our enterprise [been] understood that our teachers were to refund the amount expended in getting them to [the point] of their destination, should they find themselves [able] to do it. ... [I] paid $\$ 300$ for each of your passages in the steamer to the mouth of the Columbia River, and have given to Mr. Thurston $\$ 50$ for the passage . . . across the Isthmus, and requested him to pay additional necessary expense and call on [me to] refund it to him. . . . My impression is, that you will obtain compensations in Oregon, and that you [will be] thus enabled to refund, to a greater or less [extent]. Should you do it, the money refunded [will] be expended in sending out more teachers . .."6

The teachers traveled on mule-back twenty miles across the Isthmus of Panama, their trunks also being carried by mules. Traveling in this manner the women had to be very precise regarding the weight of their trunks -- each trunk could weigh no more than 115 pounds or the mules could not carry them. From the Isthmus they traveled up the Chagres River to a "land carriage," which took them the rest of the way to the eastern side of the continent. From there they sailed up the Pacific Coast aboard the steamer California to Oregon, where they arrived in the late spring of $1851 .{ }^{7}$

\footnotetext{
6 Gaines Papers, reel 1, box 1, folder 2, frame 00056. Letter to the teachers destined for Oregon from William Slade, dated New York, March 12, 1851. Of the teachers accompanying Margaret Wands, Elizabeth Lincoln later married Alonzo A. Skinner; Sarah Smith became Alanson Beers's wife, and after his death she n:arried a Mr. Kline, of Albany, Oregon; Mary Gray married Benjamin Franklin McLench, who incidentally was also the brother-in-law of Samuel Thurston; and Elizabeth Millar married Joseph G. Wilson.

7 Ibid., frame 00060. Letter to Margaret Wands from William Slade, dated Middlebury, Vermont, February 19, 1851.
} 
Back in Oregon and still deeply involved in the battle with the Territorial Legislature over the omnibus bill, Governor Gaines busied himself in composing a few paragraphs about education in the Territory. He later omitted the passage from his address to a special session of the Legislative Assembly in July of 1852; however, the passage itself survived to relate his opinion regarding the dubious activities of certain individuals and their lack of respect toward the institution of education:

"The subject of the grants made by Congress to the territory for the establishment and endowment of a university ... demands your attention. The importance of the matter arises from the importance of education itself. . . A fund should be created, and over which such guards should be thrown, as to prevent mismanagement or waste. It should be so managed as to be made to yield the greatest amount of revenue. It should be sacredly devoted to the advancement of the cause of education... As yet no part of the property granted by Congress for these purposes has been taken charge of in behalf of the territory. With respect to Oregon City claims, it is well known that the right of Congress to dispose of it, as it has done, has been denied by some, who set up an adverse title to it . .."8

Continuing on the subject, Gaines stood firm in his resolve:

"If the territory has the right to apply for the establishment of a university, some one duly authorized for the purpose should take possession of it at once and enforce the rights of the Territory. Nearly two years have elapsed since Congress made the grant; the income of the property for that period if rightly managed would go far towards the establishment of a noble seat of learning. Instead of being received for that purpose it is appropriated mainly by a single individual. To recover it back will be expensive, if not difficult. The income and benefits of the property, pricely as they are, still continue to be enjoyed by those who have no authority under the laws of Congress, or of this Territory to receive them. No power adequately exists by laws, by which the property or its income can be taken for the purpose of the grant. Further action by the Legislative Assembly is needed. I therefore recommend that

\footnotetext{
$8 \mathrm{lbid}$, frame 00250,00254 . This document appears out of order in the microfilm version of these papers.
} 
such steps be taken as the great importance of the subject requires, and as will best subserve the interests of the territory at large." 9

Of course, and as previously mentioned, the Assembly did not take steps to provide for and establish Oregon's university until after Gaines left the office of governor; however, the above passage shows his character and intent regarding the value of education in the Oregon Territory and the United States.

While the subject of education in the Territory troubled Gaines, other issues soon became paramount. During the winter of 1850 Governor Gaines received a letter from Samuel Thurston notifying him of Anson Dart's appointment as Superintendent of Indian Affairs for the Oregon Territory.

Dart's position came as the result of the passage of a bill titled "An Act authorizing Negotiation of Treaties with the Indian Tribes in the Territory of

9 Ibid. I suspect the land Gaines is referring to may be that formerly owned by John McLoughlin, of the Hudson's Bay Company, absconded by Samuel Thurston and others through the passage of "An act to create the Office of Surveyor-General of the Public Lands in Oregon, and to provide of the Survey, and to make Donations to Settlers of the said Public Lands." See also Gaines Papers, reel 4, box 7, folder 4, frame 00168 . In a letter to Thurston declaring his opposition to the clause that deprived McLouglin of his land, Gaines writes, "Your land bill gives very general satisfaction except so far as it deprives Dr. McLouglin and those claiming under him of their property in this city. . . I regret that . . . personal legislation should have found a place in the bill. . The town sites are all a great deal more valuable than other claims, some of them give a large fortune to the claimant, and had the bill provided for appropriating a portion of [the] solo lots in all of [these] to educational [purposes] I think it would have given more [benefit]. . . I have conversed [with individuals] from all parts [of this territory with regard to the] H. B. Company . . . I have never exchanged a [harsh word di]rectly or indirectly with any member of [the Com]pany on this subject . . . [something] may be done on terms much more reasonable. ..." Further, the piece of property referred to may have been in the possession of either George Abernethy or Joseph Lane at the time of Gaines's address. If so, this explains (from a political standpoint at least) why Gaines omitted it from his address. First, the controversy over the Oregon City claim of John McLouglin was a hot issue; and second, Gaines probably wanted to avoid further discord with the Legislative Assembly, or Lane for that matter, desiring instead to accomplish the task of settling the location matter and other important issues. For further reading on the land swindle and Thurston's vendetta against McLouglin, see Clark, p. 232 and Bancroft, pp. 114-132. There is irony in this situation in that Lane may have owned the land endowed for educational purposes yet, on the other hand, he purported to be concerned about educational opportunities for the children of the Territory. See Gaines Papers, reel 1, box 1, folder 2 , frame 00054, letter from Joseph Lane to Governor Slade, July 31, 1849. 
Oregon, for the Extinguishment of their Claims to Lands lying West of the Cascade Mountains, and for other Purposes," enacted into law by Congress on June 5,1850 . Within a month, on July 9,1850 , Thurston wrote a note introducing Dart to Gaines:

"The bearer of this is Dr. Anson Dart, Superintendent of Indian Affairs for Oregon, of course I need not say more. I hope \& doubt not you will cooperate with him in all honorable ways. . . You [are hereby] released of the duties of this department by the passage of the bill under which Mr. Dart was appointed, but your salary is continued the same . . . you are, however, at my suggestion, appointed chairman of the Board of Commissioners which you will or will not fill at your pleasure."10

In a letter of reply Gaines thanked Thurston for his note regarding Dart, commenting further, "I have been [here] but a short time but have been very vigilant with endeavors, to ascertain the wants of the people."11 One thing the people of the Oregon Territory wanted was a peaceful solution to problems with Native Americans over land claims. Previously, in October 1850, Gaines wrote a report on the condition of Indian affairs in the Territory, mailing it to Luke Lea, Commissioner of Indian Affairs. ${ }^{12}$ In early 1851 the Governor received further instructions for negotiating treaties with the Indian tribes west of the Cascade Mountains. ${ }^{13}$ The region in which the commissioners were to

10 Ibid., reel 2, box 4, folder 2. frame 00479. Gaines received an annual salary of $\$ 3,000$ to perform the duties of governor. While governor Lane not only received a salary of $\$ 2,500$ to perform his gubernatorial duties, but also received an additional $\$ 1,500$ annually to perform the duties of the Superintendent of Indian Affairs.

11 Ibid., reel 4, box 7, folder 4, frame 00168 . There is no date on this letter due to the fire at Albany, New York. I ascertain that Gaines wrote the letter sometime between November 1850 and February 1851, as it also mentions the Donation Law, enacted by Congress on September 27, 1850, McLoughlin, and the rival claims at Oregon City.

12 Ibid., reel 2, box 4, folder 4, frame 00586 . Letter from Luke Lea, Commissioner of Indian Affairs, to Governor Gaines, dated Department of the Interior, Office of Indian Affairs, February $7,1851$.

13 Ibid., reel 2, box 4, folder 3, frame 00520. Due to fire damage, both the date and author of this letter have been destroyed. The letter's author received instructions from the Secretary of the Interior to communicate with Gaines regarding his duties as Commissioner. 
treat with the Indians encompassed the area of land situated west of the Cascade Mountains, extending to the Pacific Ocean, and reaching from fortytwo to forty-nine degrees. With this in mind, the commissioners received instructions to inquire into any agreements already existing between the different tribes. Numerous Indians inhabited the region, but very little knowledge existed as to "their temper \& disposition." 14 Settlers of the region felt uneasy because they had worked hard at improving the land, yet they held no "title to any portion of the soil."15 This feeling became even more pronounced after Congress approved the Donation Land Law on September 27,1850 .

Thus, the primary objective of the government in this matter centered on extinguishing the Indians' title to the land, and negotiating a settlement with the Native Americans became the goal of the commissioners. Before beginning their duties, the commissioners wrote a letter to Lea outlining their responsibilities along with their concerns about the task of treaty negotiation. First, they informed him that they had "secured the services of a secretary; and an interpreter to the board," noting also a concern regarding traveling expenses. ${ }^{16} \mathrm{Next}$, the commissioners stated the need for some type of military escort and a concern regarding the lack of funds for that purpose:

See also Carey, p. 564, foot note 29. I suspect the letter Carey cites, written by "A. S. Loughery, acting commissioner of indian (sic) affairs, October 25, 1850," is a copy of the letter referred to above.

14 Ibid.

15 Ibid.

${ }^{16}$ Gaines Papers, reel 3, box 6, folder 3, frame 00515. The commissioners expressed the opinion that " 10 cents per mile, owing to the high price of transportation will be entirely inadequate to meet the expenses ..." for the secretary and interpreter, let alone themselves. Further, they asserted, "this added to the high price of labor and provisions, will render it impossible for us to procure the services of any one (except for the purposes of ordinary labor) for less than five dollars, per day, and expenses ... We, therefore, respectfully request that we be permitted, to employ a secretary upon these terms, otherwise, we think we 
"The Indians in the Willamette [Valley and] lower Columbia are peaceably and friendly [dis]posed, and with them, we do not apprehend [any] use for a military force; but there are other tribes both north and south of those rivers, who are more wild, and fierce, in their disposition, and to treat successfully with them it is important to appear among them with a force sufficient to awe them into respect. This is not only necessary to the success of any proposed treaty, but to the safety of the commission, and should [we be] left to hire such force to accompany us the expense would soon exhaust the already insufficient appropriations of Congress, for these treaty making purposes. We hope this matter will see your consideration." 17

The original intent in treating with the Indians of the Willamette Valley was to move them east of the Cascade Mountains peacefully; however, the commissioners had information that the tribes in the Valley would not agree to their complete removal from their ancient homeland. The commissioners declared,

"We are well satisfied, that, [it would be] impossible to remove the Indians of the [Willamette] and lower Columbia Vallies, [sic] without [undo] force nor do we think it very desirable to do so. As before stated, they are friendly [and] well disposed. They live almost entirely [on roots] and the wages they receive from the whites [for] their labor; they possess little or no skill as [hunters] or warriors, and to remove them from their [native homeland] and means of procuring labor from the whites, would, in our opinion, insure their annihilation in a short time, either from want or by the hands of their more war like neighbors. General satisfaction, we believe, would be felt by the Indians, and the citizens, to allow them small reservations, of a section, and a portion of their fishing grounds." 18

To this end, Governor Gaines, Alonzo Skinner, ${ }^{19}$ and Beverly S. Allen ${ }^{20}$, as

will be unable to proceed . . . unless . . the prices should materially decline: and in that event, left to our discretion we would of course feel ourselves called [to] use all possible economy, consistent with the interest of the public."

17 Ibid.

18 Ibid.

19 Corning, p. 225. Born in Portage County, Ohio, in 1814, Alonzo A. Skinner came to the Oregon Territory in 1845, settling in Oregon City. Skinner served as a judge under the Provisional Government until Oregon became a Territory. He became a member of the Indian Commission with Gaines and Beverly S. Allen in 1851, and later served as an Indian Agent in the Rogue River Valley from 1851-52. On May 22, 1856, he married Eliza Lincoln who was one of the five school teachers sent to Oregon by Governor William Slade of 
commissioners, set out to negotiate treaties with the Indians of the Willamette

Valley in April and May of 1851. In performing this duty the commissioners

received eight dollars per day plus traveling expenses. Governor Gaines

became responsible for recording the expenditures of the treaty process and

providing reports to the federal government on the same. Regarding

compensation to the Indians for their lands, the commissioners received the

following instructions from Lea:

"As to the price to be paid, that will [de]pend on the locality of the land with reference [to] its value to the United States, if it is possible [to] make such distinctions. ... It is presumed the lands to be ceded will not be found [to] be of any very great value . . but . . . where the land is of more [value of] course a greater sum will be allowed. ... And it is extr[emely desirable] that the whole annuity be absorbed, by ... stipulation, in objects beneficial to the Indians, [and] that no part of it shall be paid to them in money. The objects provided for, should be agricultural assistance, employment of blacksmiths \& mechanics and farmers to teach them how to cultivate the land . . . and above all, ample provision for [the pur]poses of education. After providing for these objects if any portion of the money remains, it should be calculated that it be paid in goods, to be delivered to them annually in their own country."21

On March 12, 1851, Commissioners Allen and Skinner directed Josiah

\section{Parish to proceed to Champoeg and commence construction of and repair}

\footnotetext{
Vermont. Skinner served as a Circuit Judge for the Second Judicial District from 1866 1870, and afterward became Collector of Customs at Coos Bay. In 1877, due to ill health, he departed Oregon and went to California. He died at Santa Barbara, California, on April 30, 1877.

20 Bancroft, p. 208. Receiving his appointment as commissioner on August 12, 1850 , Beverly S. Allen arrived in Oregon in February of 1851. Little else is written about him. See also Gaines Papers, reel 2, box 4, folder 1, frame 00433, a letter Allen wrote to Governor Gaines from the Chagris River on June 22, 1851, discussing his voyage to the East Coast across the Isthmus of Panama; contained in folder 7, frame 00801 of the same box and reel, is a letter from Allen to Gaines, dated Huntington, February 5, 1852, that tells of being home and discusses happenings in the Washington City political scene; and reel 3 , box 5 , folder 1 , frame 00044, a letter that demonstrates Allen stayed on the East Coast, possibly taking a job in Washington City. In this letter, dated Washington City, June [?] 1852, Allen comments on small accounting errors in Gaines's records as Disbursing Agent for the Commission appointed to treat with the Indians of the Oregon Territory.

21 Gaines Papers, reel 3, box 6, folder 3, frame 00520.
} 
work on buildings for the purposes of treaty negotiation. Robert Newell donated existing buildings for the purpose. Moreover, Skinner and Allen directed Parish to purchase tables and kitchen furnishings, flour, beef and other food, "with an injunction to have a reasonable economy in view, such as is not inconsistent with the requirements of convenience and comfort."22 They also noted,

"Should you know of any person, of ardent spirits, in that portion of the Indian Country, contrary to the intercourse laws of the United States, you will take such steps as may be suggested to suppress the same as it is our purpose to discontinue such practice, as leading, not only to the destruction of the Indians, but endangering the peace of the community and lessening our chances of affecting successful negotiations with the different tribes." 23

The Commission successfully negotiated a treaty with the Santiam Band of the Calapooya Indians at Champoeg, as noted in a communication to Anson

Dart:

"The bearers of this [letter] are the chiefs of the Santiam Band of the Callapooyas (sic) and visit you, for the purpose of securing a suit of clothes, each, in accordance with your instructions to Mr. Parrish, upon that subject. We have the pleasure of informing you that we have just concluded a treaty with them and their tribe for the country lying between the Molala (sic) River, and a line about half way between the Calapooya River and the MacKenzie (sic) fork, from North to South, and from the Wallamette (sic) to the base of the Cascades from East to West reserving to them a small tract of land lying about Edgar's Ferry, between the North fork of the Santiam River, and the first creek to the South of that river, providing for all the settlers within said bounds, by securing their claims to them, and stipulating that, no other claims shall be taken within the limits of their reservation. All efforts to remove them from the country, proved to be unavailing. The settlers, mostly live upon the creek South of [the] River, their neighbors live altogether on the [North] of the creek, so that the reserve will [not] interfere with the convenience of the settle[rs.] We think perhaps, it would be better for you to take some public

22 Ibid., frame 00524. Letter to Josiah Parish, Indian sub agent, from Beverly Allen and Alonzo Skinner, dated Office of the Commissioner, Oregon City, March 12 [1851].

23 Ibid. 
step to [instruct] whites not to settle in said reserve, as [they] could not acquire any rights to claim [the land] taken, provided the Senate ratifies the treaty. ..."24

Three days later, on April 19, 1851, in a report to Luke Lea, the Commissioners noted the successful conclusion of a treaty with the Tuality Band of the Calapooya Indians; however, they also complained about the "high prices of provisions," stating further that if Congress did not appropriate additional funds soon, "we shall be compelled to suspend our operations in a short time."25 Gaines, Skinner, and Allen successfully negotiated six treaties that spring before receiving official word that Congress had abolished the treaty commission the previous February. Besides the two treaties negotiated at Champoeg, they had, by early May, successfully concluded treaties with the Yamhill and Luckamute bands of the Calapooya Tribe and two bands of the Mollolas. The land purchased from the Native Americans now comprised the Willamette Valley, "extending from a little below Oregon City, Southward to Mary's River, being the most valuable and thickly settled part of the district. ..."26 Only two small bands remained in residence in the area between the Columbia River and Oregon City, and they lived below and opposite of the town. The Commission noted that the "Oregon Land Bill" made negotiations with the last four tribes difficult because it allowed the settlers to acquire the land before extinguishing the Indian's title. Further complicating the issue of

\footnotetext{
24 Ibid., frame 00528. Report to Dr. Anson Dart, from Commissioners Allen, Gaines, and Skinner, dated Champoeg, April 16th, 1851.

25 Ibid., frames 00530-00531. Due to the fire, I am unable to determine the recipient of the letter on frame 00530. I can only assume the Commission wrote it to Lea because of the nature of their earlier communications. Further, it may have been a cover letter to their report on the Santiam and Tuality treaties.

26 Ibid., frame 00537. Letter from Commissioners Gaines, Skinner, and Allen, to Luke Lea, dated Oregon City, O. T., May [?, 1851].
} 
title was the natives' refusal to depart their ancient homeland. The Commissioners wrote,

". . . the natives of Western Oregon, so [far as] we have seen, without exception are possessed of local attachments of the [land] distinguishing them from the nomad races . . . the habitations of these people are, so far as regards place, permanent, but, hereditary, divided into bands or families reduced in number, but, retaining each their separate [area] occupying their own lodges in the different districts [of the] country, having no generic names and no ties but a common language. . . Since the period now about thirty years past, [when] the scurge (sic) of a before unknown disease, smote down [all at] once the power and spirit of these tribes, their decreasing remnants seem to have singled out a few spots in their ancient domains where they might abide their fate. . . We therefore found ourselves compelled . . . to accede to reservations ... for the most part of grounds unfitted for cultivation, but suited for the familiar habits of the Indians. The Calapooyas . . . dwell chiefly in low and marshy spots ... while the Moolalas (sic), . . inhabit the woody slopes of the Cascade Mountains. . . ."27

According to the Commissioners, the Indians declared themselves dependent upon the white settlers. Furthermore, they stated that over the years they had received encouragement from the missionaries and early settlers to become dependent on the white man and for that reason they felt they should remain in the Willamette Valley. The Native Americans showed great intelligence in this regard -- reasoning that if the white man at first wanted the Indian to depend upon them, then why would they wish to send them away to a defenseless region? If the Great White Father in Washington truly considered the Indians his children, then why would he send them to a region where they would surely perish? While negotiating and fixing the boundaries for the reservations, the Commissioners asked the Indians if they

27 Ibid. 
knew of any places unoccupied by white settlers and the answer invariably came back, "Where are there none of you?"28

The reservations, if approved by Congress, would allow the Natives access to their familiar habitats for fishing, digging for roots, and such, without interfering with white settlements in the area. Thus the six treaties negotiated by Gaines, Skinner, and Allen, allowed the Natives to remain in the valley on reservations. Sadly, Congress never ratified the treaties negotiated by the Gaines Commission. Beverly Allen left the Oregon Territory shortly after the Gaines Commission ceased its function. Alonzo Skinner remained in Oregon and soon became active as an Indian agent in the southern portion of the Territory. Anson Dart took over the treaty negotiations during the summer of 1851 and made a total of thirteen treaties with the Indians of western Oregon; however, the Native Americans never realized the benefits from their good faith negotiations with him.

As word of the Donation Act of 1850 spread, settlement in the Willamette Valley rapidly increased and hostility between white settlers and Indians heightened. Tensions came to a head in the Rogue River Valley and citizens there wrote letters to Governor Gaines hoping he could help to quell the agitation. In June of 1851 James McBride sent a report to Gaines describing an altercation with Indians of the Rogue River area:

"Some of our men were drinking water at the spring; the Indians fired at the them . . . but without effect . . . shooting was a pretty constant roar [from] both sides. ... [O]ur men would charge on them, and they would retire a hundred yards or so into the scattering oak and as our men returned they pursued them back again. . . . [W] we were informed by the Shasta Indians that the Rogue River Indians had determined to . . . kill all the white men they could,

28 Ibid. 
and take all the property in their power. They had taken the property they could carry away from both the defeated companies, when the white men were killed--And treated the ladies of the dead, with great indignity and contempt. Upon the whole aspect of things throughout the Rogue River country, it is my undoubted conviction that [they] intend to do white men as [much damage as] they can both by killing [them] and taking property. . . ."29

Letters arrived almost daily in June carrying with them detailed accounts of the atrocities in the Umpqua Valley and southern counties of the Willamette Valley. On June 14, 1851, Gaines received a letter from Henry Spalding on behalf of the settlers living in the southern portion of the Territory. Spalding declared,

"They desire most earnestly that you issue a proclamation calling upon or allowing the citizens of the Ter[ritory] to organize in self defense for self protection against the Indians inhabiting the southern and the northern district .. . lately within 20 miles of the border settlement on the Umpqua. Eight white men are known to have been murdered, some in a most brutal \& horrible manner. Many of these murders are known to have been perpetrated by Indians who had professed friendship \& who had secured the confidence of their victims \& were at the time receiving favors at their hands. This should teach all as it has long since taught me that no confidence can be placed in the Indian." 30

The following tells of an attack on a party of ten men near the Coquille River

in Southern Oregon:

"After having descended the Coquille River for about the distance of fifty miles when within a few miles of the ocean, on about latitude 43 " 10 , we were attacked by about one hundred and fifty Indians . . . in such a manner as rendered our arms of but little or no use, and in one moments time we were entirely disarmed and the Indians commenced murdering us by beating us with clubs and cutting and stabbing us with their large knives or cutlasses ...

29 Ibid., reel 2, box 4, folder 4, frame 00601. Correspondence from James McBride addressed to Governor Gaines, dated Tuesday, June 3, [1851]. I assume this is a report as it has no formal salutation, and appears to be more of a journal or report describing the event. 30 Ibid., frame 00613 . Letter from Henry H. Spalding to John Gaines, Governor of Oregon Territory, dated Kalapooya, June 14, 1851. 
killed six of the party \& two of us, Mr. Brush and myself made our escape and went south to Port Orford and I have learned since ... that Mr. Williams and [Mr.] Heddin escaped ... . to the Umpqua settlement both badly wounded. This statement is made for the purpose of appealing to you as the commander and chief of the Militia of the Territory of Oregon as well as in the name of humanity to cause a force of sufficient numbers to be raised and marched immediately to the scene of massacre and there chastise those savage murderers as it is right and proper they should be." 31

Accounts of events in the southern portion of the Territory also appeared in the territorial news. The Oregon Statesman of July 4, 1851, carried the following information in a letter to the editor on page two:

"Gen. Lane passed here last week en route to the mines. During his absence from the mines, one of his Indian miners has been murdered, and others driven off. The unfortunate Indian was got by--it is supposed Oregon men, (after being frightened so that he was speechless), simply because he would not speak. There are several reports of the matter in circulation--all of which agree that it was an unprovoked attack on the Indian. . . ."32

Lane wrote a letter to the editor of the Statesman on July 8,1851 , regarding information given to him by the Indians:

". . I had a conversation with a considerable number of Indians ... who gave me a terrible account of the invasion of their country by our people--that they had come on horses, in great numbers, invading every portion of it--that they now were afraid to lay down to sleep, for fear the white people would be upon them before they could wake--that they were tired of war, and now wanted peace. ..."33

Due to the escalation of violence in Southern Oregon, Gaines contacted military personnel regarding the necessity of sending troops to that

\footnotetext{
31 Ibid., frame 00625, Letter to Governor Gainas from W. G. [T'Vault?]. Water damage renders the signature on this letter barely readable, and the fire destroyed the date; however, I ascertain it to have been written around the first week of June, 1851.

32 Oregon Statesman, July 4, 1851, p. 2. Signed "Ewald," this letter is dated Mt. Yoncalla, Umpqua Co., June 23, 1851.

33 Ibid., July 22,1851, p. 2. Letter to the editor from Joseph Lane, dated Governor's Camp, Rogue River, July 8, 1851.
} 
region; however, he became disappointed when he received the response to his request from $P$. J. Wyman:

". . . the major has only heavy artillery ... . which he would not be able to transport ... [and] to bring over the mountains howitzers [from] Steliacoom would take two weeks at least. To take to the field with only about twenty men armed as infantry merely, would be, in his [opinion] without any decisive results [and] he therefore respectfully though at the same time with regret declines sending them." ${ }^{\text {34 }}$

Nevertheless, many individuals showed a willingness to assist Gaines with the troubled Indians of Southern Oregon. On June 5, 1851, John Thorp wrote a letter to Gaines offering his services. He suggested to the Governor the "propriety of ordering . . . a company of mounted volunteers to serve as Rangers," whose duties would include conducting reconnaisance parties in the southern portion of the Oregon Territory, "including all that portion of country lying between the California Road and the Coast Range of mountains, and north of the Rogue River and down that River, to its mouth thence along the coast as far as the line between this Territory and the State of California." 35 Thorp volunteered to command the company at the rank of major suggesting also,

". . . that the company consist of fifty privates including non commissioned officers with one Captain, 2 Lieutenants and one Ensign making fifty four in all, to serve sixty days, unless sooner discharged, to furnish their own outfit entire, the same to be valued upon mustering the men into service. . . ."36

Thorp demonstrated a desire to assist in creating an understanding between the Indians and whites in the area, but also showed anger toward the Native

34 Gaines Papers, reel 2, box 4, folder 4, frame 00611. Letter from P. J. Wyman to Governor Gaines, date destroyed by fire.

35 Ibid., frame 00607. Letter from John Thorp to Governor Gaines, dated June 5, 1851. 36 lbid. 
Americans for their hostility toward the settlers. He continued by suggesting the need,

". . to cause the surrender of such among them as may have been engaged in the murder of the unfortunate individual, that was killed on the trail the other side of the Umpqua Valley, \& also to demand and obtain the murderers of Mr. Newton in the year '46, also to effect an understanding with a large band or tribe ... resid[ing] on the cuast near to the line between us and California. Those Indians near the line are represented as being numerous and altogether hostile. Should there be no arrangements made with these tribes during the dry part of the year, our people will inevitably suffer much, and very much, in the coming rainy season, as they are well aware of the fact that a force of horse cannot successfully march in that part of the country in the winter." 37

Unrest spread throughout the Territory regarding Indians and land rights. On

June 18, 1851, Gaines received a letter from H. A. Goldsborough, of Olympia, Lewis County, in the northern portion of the Territory, describing the situation there:

"Our citizens here are exceedingly chagrined and disappointed at the nonarrival, of the commissioner to treat with the Indians - any Indian agent, any Government officer whatever -- Beyond all question, so far as the relations with the Natives are concerned, this portion of the Territory, requires more immediate attention, on the part of the Government than any other part of Oregon West of the Cascades, and it has been so continually, so always absolutly (sic) neglected, that I cannot but sympathize with them in their feelings of indignation -- they say and feel that all the interests, all the action, and apparently all the thoughts of the Oregon Government officers, are confined and concentrated to that portion of the country south of the Columbia-- They have understood that the Board of Commissioners have been disolved (sic) and that $\mathrm{Dr}$. Dart has gone on an amateur expedition east of the Cascades perfectly regardless and unmindful of the Puget Sound District west of the Cascades. . . Our Indians have had the word of promise so often \& so long broken to them that they are beginning to place no

37 Ibid. 
confidence in the oft repeated assertion that the Government will pay for the land \& consequently they are becoming daily more troublesome. . . ."38

Further commenting on Anson Dart's absence, Goldsborough pleaded with Gaines to do something about the situation:

"Occasionally the Indians are rather savage and they may commit some act of personal aggression upon a white which I verily believe would be followed by an indiscriminate massacre, such are the feelings recently engendered among the whites of the Sound . . . cannot you persuade the Superintendent of Indian Affairs to leave off his pleasure excursions for a time, and give a personal examination into our Indian relations? . . . A visit from you now would be of material benefit to us in our Indian relations, especially if you were accompanied by an Indian agent-- Tho you might not have authority to do anything definite, still your presence as Governor of the Territory, with an occasional talk with the Chiefs would be of essential service to us, to you and to the Whigs generally!!"39

Although the situation in the Northern Oregon Territory appeared tense, Gaines felt it necessary to depart, in late June, for the southern portion of the Territory due to the increased violent hostility. Further, considering Anson Dart's absence from the scene, Gaines decided to do what he could to negotiate peace between the Indians and white settlers in Southern Oregon. He arrived at Rogue River on June 29, 1851, shortly after Major Kearney's departure with his troops and thirty Indian prisoners. In a report to Secretary of War C. M. Conrad, Gaines wrote,

"Having but ten men with me, I immediately dispatched an express to him, which overtook him at the fork of the Caskill Mountains, by which I requested him, to suspend his march until I could see him, which, very much to my regret $\mathrm{He}$ declined. Finding myself thus left in the heart of the Enemies country, with

\footnotetext{
38 Ibid., frame 00617. Letter to Governor Gaines from H. A. Goldsborough, dated Olympia, Lewis County, Oregon Territory, June 18, 1851.

39 lbid.
} 
so few men I . . . sent into the Umpqua Valley to procure an interpreter; and busied myself in endeavors, to learn the whereabouts and disposition of the enemy. It being understood, that Major Kearney, intended to take the prisoners (all of whom were women and children) to San Francisco, and return them by water to Oregon, the Indians were said to be highly exasperated; and, that any attempt to terminate hostilities with them, would [be] unavailing." 40

In this instance Gaines found an ally in Joseph Lane who, returning from the

mines to the Umpqua Valley, met with Kearney. On July 8, 1851, in a letter to

the editor of the Oregon Statesman, Lane wrote,

"I wrote you from Camp Stewart a brief account of Major Kearny's (sic) operations in the Rogue River country, and that he had very properly determined to take the prisoners with him. I arrived a the Chasta (sic) diggings on the morning of the 30th ult., which is within ten miles of the road leading to California, on which the Major would pass. By Wednesday noon I had my business settled up and was ready to return to Oregon. Lieut. Irving came in and reported that the Major had passed and would camp near Chasta Bute (sic) . . . [Irving] immediately dispatched a courier to Major Kearney bearing my letter, proposing to take charge of the prisoners. . . The Major promptly dispatched Capt. Walker with them, who arrived at my camp just before daylight on Thursday morning. . . . We immediately set out, and arrived here safe with all the prisoners yesterday noon, where I had the pleasure of finding Gov. Gaines with some fifteen men. To him I delivered the prisoners. His intention is to see the Indians and if possible make peace." 41

Gaines reported to Secretary of War C. M. Conrad that Lane,

40 Ibid., reel 3, Box 6, folder 3, frame 00554. Letter to C. M. Conrad, Secretary of War, Washington City, from John P. Gaines, Governor of Oregon, dated Oregon City, September 28,1851 . Like other documents in this collection, fire and water damaged this report. Interestingly, I found a draft of this report on reel 2 , box 4 , folder 5 , frame 00659 , and by examining the two versions I reconstructed the report almost entirely. There are still some missing words, due the nature of revision from the draft to the final report, but it's intent is fairly complete. I have been unable to locate the Caskill Mountains on Oregon maps in the region discussed. It is possible that Gaines meant to write Siskiyou Mountains, which Kearney would have crossed to go to San Francisco. Further, Gaines obtained the information that the Indians "rejected, with scorn, Major Kearney's tender of peace," from Jesse Applegate. See Gaines Papers, reel 2, box 4, folder 4, Frame 00629.

41 Oregon Statesman, July 22,1851, p. 2. Letter to the editor from Joseph Lane, dated Governor's Camp, Rogue River, July 8, 1851. 
". . . tendered his services, to conduct the prisoners back to Rogue River, and arrived with them at my camp on the 8th day of July. Up to this time, the Indians had evinced no disposition, whatever, to come to terms. Indeed I was informed, that they rejected, with scorn, Major Kearney's tender of peace. But when they saw their women and children returning; and received an assurance from General Lane, that they would be kindly received at my camp; and that peace would be granted them, if they would come in, and give assurances of a friendly disposition, they promised to do [that], and acknowledged their condition to be wretched and their utter inability to prosecute a war with the whites. Being thus in possession of the prisoners, I found [it] necessary, further, to increase my force, which, I did [to twenty] five men, or thereabouts; and having ... procured an interpreter, I sent him, with a [half-breed] and one of the prisoners, to the Indians, By [which means] they were induced to come in, and the result was a treaty of peace. . "42

In his report to the Secretary of War, Gaines expressed frustration in

procuring a military force and a reliable Indian agency in the Southern Oregon

Territory. He added,

"My great reliance in the efficiency of the treaty, was based upon my firm conviction that both would have been steadily furnished. Had I believed, at the time that both or either would have failed, I should have had but little confidence that peace would have been preserved, but contrary to my expectation, the Indians have up to this time, shown a disposition to observe the treaty and keep peace." 43

The Gaines Peace Treaty, created on July 14, 1851, suspended the hostilities in the region and established (albeit temporarily) peace.

Represented by their chiefs, the Rogue River Indians agreed to place themselves "under the ... care, guardian[ship] and protection" of the United States Government; to bring to the attention of the United States Government any disputes between themselves and the white settlers; and to surrender to the United States Government the property taken by them from the white settlers. In exchange, the United States Government agreed to return to the

42 Gaines Papers, reel 3, box 6, folder 3, frame 00554.

43 Ibid. 
Indians all property and prisoners taken from them by the American settlers. 44

Commentary regarding the peace treaty appeared in the territorial press and Gaines received censure again from Bush and company in the Statesman. In the August 5, 1851 edition of the paper Bush wrote,

"An intelligent Umpqua friend, writing under date of July 23d, says: "The treaty is pronounced a perfect farce. Gov. Gaines was in the Indian country for some time and talked with a few Rogue River Indians.--The hostile savages refused to meet him. They are the Grave Creek and Sisco Mountain Indians. The tribes with which he treated are now, and, as I understand, ever have been friendly. In fact they are abused by neighboring tribes for being so. The treaty is not only insufficient, but every act of the Governor is, also." The general opinion entertained of this "treaty" in the Southern part of the Territory may be gathered from the allusion made to it by our regular Umpqua correspondent, "Ewald," whose interesting letter will be found in another column. . . " 45

"Ewald's" letter told the story of Lieutenant Irving's kidnapping and escape from the Indians and a Frenchman on the Fourth of July. He concluded his letter, "This is a fine comment upon the treaty which was made a few days since." 46 Reaction to "Ewald's" letter appeared in the Oregonian on August 9, 1851 , as a letter to the editor from S. A. Clark:

"I noticed in the "Statesman" of this week a letter from its 'interesting correspondent,' . . . in Umpqua, also an editorial originating therefrom. As the

44 Ibid., frame 00551. "Copy of the Treaty with Rogue River Indians," dated July 18, 1851. Under the Governor's signature appeared the marks ( $X$ next to each name) of the eleven Indian chiefs representing the Rogue River Indians: Cho he quash, Ha Malah, Tanahawestab, Apas, Tecomitorut, Tekelahweah, Tecloweah, Lemeweakosea, Yewahkn, Leheantkahwah, and Holalewaneke. Among those representing the white settlers were Daniel Porter, William Rector, Henry Spalding, Mathew Hale, C. M. Walker, James Gay, J. W. Perit Huntington, and P. P. Bailey.

45 "Lieut. Irving Kidnapped--His Escape, \&c.," Oregon Statesman, August 5, 1851, p. 2

46 Oregon Statesman, letter to editor Asahel Bush from "Ewald," dated Mount Yoncalla, July 25,1851, p. 2 
'facts' of the one and inferences of the other are alike false, I beg to hand you another version. I heard the story of Lieut. [sic]lrving in Shasta more than forty days since--two weeks at least before the treaty was made--and the people in that region intend to have it included in the next edition of 'Assops Fables,' I was at the Governor's camp during the negotiations for peace, and the treaty was made with the thirteen head chiefs of Rogue River nation. It is absurd to pretend, as they have, that these things have occurred since. The evident intention is, to ridicule Gov. Gaines by any means whatever." 47

Reporting to the Secretary of War, in September of 1851, Gaines

urged the Federal Government to establish some sort of military presence in

the Rogue and Umpqua Valleys to protect the settlers and miners from the

Indians in that region:

"Notwithstanding their naturally thievish disposition, being sorely tempted, by the numerous opportunities offered them to commit depredations, by persons going and coming from the mines, when they are well aware of the distance it is to where troops are stationed, and the respite they would have before they could be punished for the thefts, the temptation could be removed . . . if there were a small number of troops stationed somewhere [in] either the valley of Umpqua or Rogue River, and [on a] route from this valley to the mining districts, [they would] then be restrained from committing any depredations for fear of immediate punishment. [Immediate] punishment with an Indian, is much more [beneficial] than, a terrible punishment long delayed." 48

Gaines expressed regret that the Federal Government did not deem it necessary to station a small military presence where most needed, choosing instead to locate the soldiers on the coast at Port Orford from which no known road yet existed to the Rogue River or Umpqua valleys. He concluded,

47 Oregonian, letter from S. A. Clark to editor Thomas Dryer, dated August 8, 1851, p. 2. Gaines may have negotiated peace with thirteen chiefs of the Rogue River Indians; however, only eleven signed the treaty.

48 Gaines Papers, reel 3, box 4, folder 4, frame 00554. Letter to C. M. Conrad from John P. Gaines, September 28, 1851. 
"I can [only] therefore repeat my belief, that without [a] military post in either the Umpqua or Rogue [River] Valley, I apprehend great trouble and expense from the hostilities and depredations of these Indians." 49

Joseph Lane agreed with Gaines, writing from Camp Stewart, Rogue River, on June 28,1851 ,

"The establishing of a garrison in this district of country will be necessary for the maintenance of peace. That done, and a good agent located here, we shall have no more trouble in this quarter." 50

Henry Spalding served as an Indian agent for a short time in the Rogue River region; however, neither the settlers nor Indians got along with him.

Alonzo Skinner, formerly of the Gaines Commission, arrived in the Rogue River Valley during the fall of 1851, replacing Spalding as the region's Indian agent. Many citizens viewed Skinner's arrival with pleasure as the following letter from J. W. Perit Huntington demonstrates:

"It is with pleasure I learn that we are at length to have an Agent stationed here and that pleasure is not lessened by the fact that it is to be some other than the imbecile Spaulding (sic)--The Indians of this valley remain . . . very much discontented and complain loudly of the treachery of Mr. Spaulding (sic), but no worse acts than a few petty thefts have been committed by them. Those of the South Umpqua are however becoming bolder every day and were it not for the fact that the immigration is filling up that country very rapidly, I should apprehend some danger of hostilities, but if they remain quiet a few weeks longer the white population will be sufficient to quell without assistance any disturbance that may arise.-- The presence of Judge Skinner (who arrived here today) and the distribution of a few presents will I think be productive of much good and will establish a good feeling on the part of the Indians which if neglected now can never be done hereafter. . . I . . . hear [of] no violation of the Treaty as yet but an outbreak is confidently expected by many of the returning miners ... I I think it can be averted by the presence

49 Ibid.

50 Oregon Statesman, July 22,1851, p. 2 . Letter to the editor from Joseph Lane, dated Camp Stewart, Rogue River, June 28, 1851. 
and action of the Agent.-- The military force would be eminently useful but I suppose that is utterly out of the question at present." 51

While Huntington demonstrated a disdain for Spalding he also showed displeasure with Anson Dart when he wrote,

"The Treaty negotiation with the Coast Indians by Dr. Dart ... for the purchase of a vast tract of country in the region of Port Orford (which he boastingly assents cost less than one and a half cents per acre) is decidedly the most absurd of all the acts of that functionary. It comprises one of the roughest ... tracts in all Oregon (notwithstanding the contrary reports of interested parties) and ninety nine hundredths of it will never be settled, and the spirit of jockeyism in which the sup[erintendent] vaunts the "good bargain" he has made in purchasing from the ignorant savages their home for goods with no value of which they are entirely unacquainted appears to me contemptible in the extreme.-- I have always been in favor of purchasing the lands of Umpqua and Rogue River Tribes as soon as the negotiations could be entered into and completed, but if it is to be done now to take advantage of the ignorance of the Indians to get the lands at as low rate as possible I think it should by all means be deferred until they learn the worth of the goods they are to receive in payment." 52

In the same letter, written around the time of Alonzo Skinner's arrival in the Rogue River region, Huntington responded to an article written in the Oregon

Statesman which continued the attack on Governor Gaines and the peace treaty at Rogue River. This time Bush had an accomplice in Anson Dart. On October 27, 1851, Huntington wrote Gaines,

"The Statesman of Oct[ober] 21st has just come to hand and I open this letter to notice the article headed "Galphinism in Oregon" -- It is very evident from the tenor of the article that Dr. Dart is a counselor and advisor of Bush in the attacks upon yourself, a fact of which I have some time been aware from a few remarks incautiously dropped by Bush in my presence in Aug[ust] last and from an extract from a private letter addressed to Dart himself ... tho' so garbled as to convey a sentiment directly contrary to the opinions of the writer himself as expressed in the whole letter. As Dr. Dart is about to proceed to

51 Gaines Papers, reel 2, box 4, folder 5 frame 00683. Letter to Governor Gaines from J. W. Perit Huntington, dated Yoncalla, Umpqua, O.T. October 26, 1851.

52 Ibid. 
Washington I think it very probable that his influence there (if he possesses any) will be exerted against you.-- Would it not therefore be politic to communicate to your friends at Washington an account of Dart's treachery and probable intentions in order that they being 'forewarned may be forearmed?"'53

In late November 1851, Jesse Applegate wrote to the Governor expressing concern regarding a letter he had written to Anson Dart, part of which was referred to and published by the Statesman to slander Gaines regarding the Rogue River treaty:

". . I I of course regret my name or act should be mixed up in the elements of discord between the officers of a Whig administration, but far more deeply do I regret the discord itself. That I replied to a letter of Dr. Dart asking information in regard to the "Origin of the difficulties in Southern Oregon" is true, and it is also true that in that letter the Rogue River treaty was freely discussed. . . An extract from my letter in the Statesman and letters from other quarters established in my mind the truth of the rumored misunderstanding between yourself and that gentleman, and inclined me to give credit to the ... charge of political unsoundness." 54

Applegate assured the Governor the letter contained "nothing personally

offensive" toward him and that if Dart wanted to he could publish it in its

53 Ibid., post script dated October 27, 1851. Huntington closes, "If you see proper to adopt that course and will notify me of it I shall then be at liberty to communicate some facts which will have an important bearing"

54 Ibid., frame 00712. Letter to Governor Gaines from Jesse Applegate, dated Yoncalla, $O$. T., November 21, 1851. It is evident from the Statesman articles that Gaines was being chastised for performing the duties of Dart; however, accounts of Dart's whereabouts during the time in question are conflicting. In his letter Applegate says that although he communicated with Dart through a series of letters on the subject of the "absence and inefficiency of the Indian Agent for this part of Oregon," he had never met Dart personally. This shows Dart was not in the area during the time in question. See reel 2, box 4, folder 4 , frame 00617 , letter to Governor Gaines from H. A. Goldsborough, dated Olympia, Lewis County, Oregon Territory, June 18,1851. Acccrding to Goldsborough, Dart was off on a pleasure expedition, and not available when the trouble began in the Rogue River, consequently Gaines appeared to appease all those involved in the Rogue River conflict. 
entirety. On November 29, 1851, Huntington again wrote the Governor on the subject:

"I am confident that the letter taken as a whole would not be considered offensive ... the portion quoted in the Statesman referred more to some of Spaulding's (sic)'s proceedings than your own. Until the arrival of Judge Skinner at this place Mr. Applegate as well as myself supposed that, as Dr. Dart had given the letter to the opposition press for publication he had made no secret of the authorship, but upon making inquiries of that gentleman he was surprised to learn that the extract was a fabrication of Bush's. Knowing Judge Skinner to be a personal and political friend of yours he handed him a copy of the letter and asked his opinion. He replied that "it contained nothing to which he thought you would object" and expresses much surprise that Dart should permit Bush to publish it and especially that he should suffer it to be so garbled. I was equally surprised and thought best to call your attention to it." 55

Gaines took his friend Huntington's advice and promptly wrote to his friends in

Washington. He forwarded the "Galphinism in Oregon" article from the

Statesman with a letter he wrote to Amory Holbrook, then in Washington City

on Territorial business, recounting Dart's part in "feeding" Asahel Bush:

"I have ascertained beyond the shadow of a doubt, that the letter from which the abstract is made, was written to Dr. Dart, and consequently furnished by him to the Editor-- This discovery, in addition to other circumstances notoriously known here, establishes the fact that the $\mathrm{Dr}$. [Sic] is a sleeping partner, or feeder of that concern-- During the past summer, when these false and malicious assaults were being made in almost every paper, as you will recollect, I had several conversations with Dr. Dart in all of which, he assured me in the most solemn manner, that so far from having given any countenance or assistance to them, he had, had no intercourse whatever with Bush; nor had he said or done anything from which such inferences could properly be drawn; That what [I] had done was proper under the circumstances ..."56

\footnotetext{
55 Ibid., frame 00726. Letter to Governor Gaines from J. W. P. Huntington, dated Yoncalla, Umpqua, November 29, 1851.

56 Ibid., frame 00732. Letter to Amory Holbrook from Governor Gaines, dated Oregon City, December 1, 1851.
} 
Describing the cause of the Indian difficulties in the Rogue River, Gaines paints a little different picture than the settlers of the region in his letter to Amory Holbrook:

"The difficulties on Rogue River commenced [in] the spring by the killing of some four or five Indians by a man [by] the name of Gage, followed up by the murder of two white men, one on Grave Creek, the other near Table Rock-Then [the murder] of several Indians at the ferry, and many other murders and [robberies]." 57

The Governor continued to tell Holbrook his version of what happened in the

Southern Oregon Territory:

". .. [There being neither] Superintendent, nor agent in the Country, the accounts [of unrest] thickening every day, letters received, and personal appeals [from settlers] made for protection, I considered it my indispensable duty to [give the matter] my immediate personal attention-- . . . A day or two before the conclu[sion of the peace treaty] . . Mr. Spalding . . arrived at my camp, was present at, and a witness to the treaty, approved it entirely, promised the Indians to see it faithfully executed, and further promised the return to them again within two weeks--On my return home I found Dr. Dart to whom I fully explained all that had been done, exhibited to him my entire correspondence with the government and others, with all of which he expressed himself perfectly satisfied-- Mr. Spalding instead of being permitted to meet his engagements with the Indians, was required to accompany Dart to Clatsop, and the Rogue River meeting was postponed until the 15th Sept[ember] ... This engagement was also disregarded, and [after] about one month of great leisure in this city, the Dr. [sic] took his departure (taking Mr. Spalding with him) to a place called [Por]t Orford on the Coast, and a messenger sent to the R[ogue] River Indians [telling them to] meet him at that place. . . [ [the Indians] declined. . . ."58

Gaines concluded by telling Holbrook that he confronted Dart upon his return from Port Orford, expressed his concern about the material that had appeared

57 Ibid.

58 Ibid. 
in the Statesman and showed him letters received from citizens "complaining loudly of the gross inattention of his department in relation to the whole matter."59

Holbrook, responding to Gaines's December 1 letter, mentioned Dart's arrival at Washington City and wrote,

"Gov. Lane ... cherishes the most friendly feeling towards you, and expresses very decidedly his intention to urge the destruction of the office of Superintendent $\&$ the reannexation of its duties to your office with an increase of salary. . . ."60

And in a post script to the same letter he added,

"Just before I left [Washington City] I met Judge U[nderhill] to whom I read your long letter \& told the whole story, stating many things which you had not written - he declared he would go instantly \& ask Dr. D's removal, but I advised him to see Lane $\&$ assist in knocking the office away from under him-The policy in my judgment is better; he thought the same--"61

Lane, now in Washington City, wrote to Gaines on January 11, 1852,

assuring him that he considered his actions in the Rogue River Indian affair

prompt, correct, sensible, and humane. Further, said Lane,

'You done the best you could, and for the best, I have so stated to the Com[missioner of] Indian Aff[ai]rs, Secretary of War, and all others with whom I have spoken [on the] subject. . . I I now feel much inclined to try to abolish the office of Supt. [sic] of Indian Affairs, and transfer the duties to the Governor (in our territory). This I say to you in confidence, as I [have] not yet determined to act, but [I am] much inclined so to do, as I know well that the Governor, (at least in Oregon) can do the double duty of Indian Affairs, and Executive duties-- Now if these duties can be performed by one man, just as

\footnotetext{
59 Ibid.

60 Ibid., frame 00779. Letter from Amory Holbrook to Governor Gaines, dated Washington, 19 Jan 1852. Post script dated January 24, 1852. Interestingly, Gaines's letter, along with one written by Amory Holbrook to Luke Lea forwarding Gaines's letter to him, found its way to the front page of the Oregon Statesman on November 22, 1853.

61 Ibid.
} 
well as by two, \& if I am correct in this conclusion, why not abolish the former. Let me hear from you upon this subject, and every other touching the interest of Oregon."62

Hearing about his friend's unhappy circumstance, former Commissioner

Beverly Allen wrote Gaines, on February 5, 1852, giving his opinion on Dart

and reassuring Gaines that he still had many friends in Washington City and

elsewhere in the country:

"I look upon Dart as a supremely selfish and unscrupulous man, that would rather crawl in the filth of darkness to procure his own ends than stand in the face of day and boldly speak his thoughts as becomes an honest and independent mind. . . I took the liberty of copying that portion of your letter relating to Dart \& his probable intentions and addressed it to the Hon C S A Williams, the M[aster] C[ommissioner] from my district with instructions to confer with Bell \& Jones of the Senate \& Gentry of the House, and such Whig friends of yours as he might know from Kentucky-- and if Dart was there to watch his movements \& inform themselves of his intentions, and if your conjectures proved correct to make an open war with him and that I would come to Washington, and see him out \&c."63

Meanwhile, back in Oregon, Indian Agent Alonzo Skinner wrote Gaines from the Rogue River Indian Agency in March of 1852 telling him of the mild winter and the "fine agricultural country."64 Skinner claimed his stock fattened faster in the Rogue Valley during January and February than they ever did in the Willamette Valley during May and June. Inviting Gaines to

62 Ibid., frame 00772. Letter to Governor Gaines from Joseph Lane, dated Washington City, January 11,1852 . One month later, in February of 1852, Lane chastised Gaines for his stand on the location issue, choosing to side with the Salem Clique. I believe this demonstrates the power of the Clique -- Lane in essence served the Clique much like a marionette responds to a puppet master. On the other hand, Lane may have been attempting to lure the Governor into his confidence in order to feed information back to Bush and the Clique.

$63 \mathrm{lbid}$., folder 7 frame 00801 . Letter to Governor Gaines from Beverly Allen, dated Huntington, February 5, 1852.

64 Ibid., frame 00824. Letter from Alonzo A. Skinner to Governor Gaines, dated Indian Agency, March 31, 1852. 
visit his "Wigwam if ever you should visit this part of the country," Skinner confessed he wanted to show off his garden where "wappatoes, turnips and cabbage [are] cultivated by my own labor." He continued his letter in this manner also mentioning that the friendly Indians he'd met with had caused no trouble,

". . . with the exception of difficulty caused by Bill whom I sent to the Willamette, and I am satisfied that Joe and Sam and most of the other chiefs are satisfied that the interest of the Indians requires that they should remain at peace with the whites ... Your friend Joe frequently inquires about you and would be much pleased to see you." 65

During the summer of 1852 General Joel Palmer became Superintendent of Indian Affairs and he negotiated another treaty with the Calapooyas -- grouping all the bands together as the Confederated Tribes of the Willamette Valley. In December of 1855 , Congress ratified a treaty with this group, allowing them reservations in the Coast Range Mountains and Yamhill County area. They received as compensation for 1470 square miles of land $\$ 155,000$ in material goods, an industrial school, and a staff of white personnel to assist in improving their general welfare and living habits. A similar treaty for the Molalla bands allowed $\$ 62,260$ in compensation. The Gaines Treaty with the Rogue River Indians did not create a lasting peace. As Gaines predicted, renewed hostilities broke out in Southern Oregon between white settlers and the Indians during 1853 , costing the government much in military expenditures. Joel Palmer, Joseph Lane, and James Nesmith, among others, negotiated the Table Rock Treaty on September 10 , 
1853, ratified by Congress on April 12,1854, and in 1855 the Natives moved onto reservations.

At the conclusion of his business in the Rogue River area Governor Gaines had returned to Oregon City with the intention of meeting his wife and children and taking them to their new home on the Clatsop Plains. The tragedy that followed left Gaines devastated; however, after the departure of his children for the States he sought companionship to soothe his loneliness. It is possible that Gaines had enrolled his younger daughters in the Clackamas County Female Seminary sometime during the spring of 1851 and very likely that during his contact with the school he became acquainted with thirty-five-year-old Margaret Wands. It is equally possible the couple met during services at the Presbyterian Church in Oregon City. Nonetheless, after his wife's death and his children's departure for the States, Governor Gaines courted Miss Wands during the spring and summer of 1852 and their relationship became intimate; 66 however, the location issue, the Rogue River Indian affair, and a man convicted of murder took up much of the Governor's time.

On February 12, 1852, Return William Everman concealed himself in a rail pen stuffing the lower portion with straw. As Cyrenius $C$. Hooker worked in his field he came within thirty yards of the pen. When he turned his back, heading away from the pen, Everman raised his rifle and shot Hooker "in the

66 Unfortunately I have been unable to locate any correspondence or other evidence to prove Gaines met Wands at the school or at church. I have found evidence that hints at the Gaines family being Presbyterian in faith, but none that proves this beyond a reasonable doubt. Moreover, I have not found any record of the courtship between Gaines and Wands and therefore what I have written here is purely conjecture on my part -- at least up to the point of their marriage. 
back with a heavy load of buck shot and slugs." 67 Watching Hooker fall to the ground, Everman left his hiding place and approached him slowly. Noticing his victim still alive Everman stopped about six feet distant from Hooker, raised his rifle and shot the man in the head.

Earlier the same day Everman's brother, Hiram, departed for the mines in the company of Samuel Goff, David Coe, and Enoch Smith. Return Everman caught up with the party later that night, telling them upon his arrival "that the deed was done, and he had settled with Hooker . . "68 Some fortyeight hours later a posse went in searcll of Return Everman. Encountering his brother Hiram, Enoch Smith, and Samuel Goff on February 14 the posse asked them if they had seen Return. Hiram Everman and Smith denied seeing Return, but Goff admitted that he had seen him. The authorities arrested Hiram Everman an accessory to the murder but let Smith and Goff go free. Goff immediately joined the posse and helped find and arrest Return Everman and David Coe on February 16, 1851 -- Everman for the murder of Hooker and Coe as an accessory to the murder. To protect himself Coe made a statement to the authorities regarding Return Everman's intentions against Hooker. A month passed during which time an investigation lead to the arrest of Enoch Smith as an accessory to the murder also.

One must remember that during the spring of 1852 the location issue occupied the pages of the Territorial press. Further, the Democratic Clique made sure the Territory's federally appointed officers got plenty of negative publicity through the Statesman. The Supreme Court Justices (Nelson,

67 "The Late Murder in Polk County," Oregon Statesman, March 9, 1852, p. 2.

68 Ibid 
Strong, and Pratt) held their courts by riding the circuits in the Territory. Judge Pratt's circuit included Polk County and he therefore presided over the murder trial of Return Everman, his brother Hiram, David Coe, and Enoch Smith. Interestingly, Reuben P. Boise, a neighbor of Hooker's, became the prosecuting attorney in this case. Moreover, among Hooker's other neighbors were other prominent members of the Clique, including James Nesmith.

A jury of his peers found Return Everman guilty of the murder of Cyrenius Hooker and Judge Pratt sentenced him "to death by hanging . . . to be carried out at 11 a.m., Tuesday, May 11, 1852."69 As a result of his role in the murder as accessory after the fact, Hiram Everman received a sentence of three years in the penitentiary. Because the Territory had yet to build a penitentiary, the court placed Everman "up for sale at a public auction on May 11 , with the highest bidder being responsible for his welfare for the next three years." 70 This left the trials of Smith and Coe who had both requested and been granted a change of venue to Yamhill County. Smith escaped from his leg irons, jumped out a window, and remained free for several days. In the meantime Coe had his trial and the jury found him not guilty to the charge of accessory to murder, thus he gained his freedom. Smith's trial began on April 22,1852 . The jury found him guilty of being an accessory to Everman in planning Hooker's murder and Pratt, whose circuit also happened to include Yamhill County, sentenced him to hang at Polk County on May 18, 1852.

The time approached for the hanging of Return Everman. Broken in spirit and attending church services Everman "was often seen on his knees

69 Branigar, Thomas, "The Murder of Cyrenius C. Hooker," Oregon Historical Quarterly, LXXV (December 1974), p. 352.

70 Ibid., p. 353. 
praying."71 A few days before his death he confessed to the murder entirely, then a few hours before his execution he declared that Enoch Smith had nothing to do with the murder of Hooker. This caused numerous individuals in Polk County to take a second look at Smith's part in the crime. They asked themselves why Everman would lie about such a thing when he appeared to have repented for murdering Hooker. As a result, several Polk County citizens took to the task of petitioning the Governor to pardon Smith. Nathaniel Ford and James McBride also wrote personal letters to Gaines stating their belief in Smith's innocence in planning the murder.

A day before Smith's execution Governor Gaines suspended it until 2:00 p.m., June 8, 1852. Several weeks later on June 7, 1852, after considering the petitions submitted on behalf of the condemned man, the Governor finally "gave Smith a full and complete pardon." 72 Interestingly, both the Oregon Statesman and the Oregonian reported on the Hooker murder in much the same manner up until the time Governor Gaines pardoned Smith. After the pardon the Statesman focused on Gaines with its usual viciousness and editorials of an equally supportive nature toward Gaines came from the Oregonian. One letter to the Statesman, signed by "A Kentuckian" accused Gaines of "turning loose on society a cold blooded, heartless murderer. ..." Not satisfied to stop there, the author cited Gaines's conduct during the Mexican War as proof that he could not "look upon blood with composure, even when shed in a just and righteous cause." Admitting he is a native of

\footnotetext{
71 Ibid., p. 354.

72 Ibid., see also Gaines Papers, reel 4, box 7, folder 8 , frame 00272 . A petition, dated August 4,1852 , on behalf of Hiram Everman also reached the Governor.
} 
Kentucky, the author continued his letter with a recitation of all the criminals from that state. He states further,

"Common sense, sir, should teach you that the prestige of Kentucky origin will not sustain you in your mental imbecility; and that Kentucky aristocracy, devoid of sense and virtue, will not pass current in this intelligent market. The people of Oregon believe that vice and virtue are not bounded by town, country or State lines. The map exhibits no vicious nor virtuous divisions of the globe, yet the history of the last two years proves that the perpetrators of crime in Oregon are nearly all from our native State. . . Enoch Smith, a native of Kentucky ... would have been executed to-day had it not been for the interference of "I, John P. Gaines," another Kentuckian, who interposed his official authority to save the credit of his native State and the neck of a murderer. . . ."73

Whether Gaines based his pardon of Smith in "feelings of personal animosity against the Judge who presided at the trial . . . [and] personal hatred, increased by recent events to an extent unknown to enlarged and liberal minds, and a proclaimed determination to trample upon and condemn the laws of the Legislative Assembly, ${ }^{74}$ remains open for speculation. Needless to say, tempers became so heated over this matter that an encounter between Gaines and Bush on the street in Oregon City resulted in the two men sparing with each other and further acrimonious words being printed -- the Statesman attacking Gaines's character and the Oregonian defending it. 75 In a matter of

73 "To His Excellency, John P. Gaines," dated Polk County, June 11, 1852, and signed "A Kentuckian." Oregon Statesman, June 15, 1852, p. 2. See also Bancroft, p. 186. According to Bancroft, Robert Newell confessed to Governor Gaines that he knew "A Kentuckian" was none other than James Nesmith. If this is true, then Nesmith lied when he said he claimed to be a native Kentuckian.

74 "The Pardon of Smith," editorial in the Oregon Statesman, June 22, 1852, p. 2.

75 For further reading on the pardon of Enoch Smith see the Oregon Statesman and the Oregonian between June 15 and July $3,1852$. 
weeks the incident had blown over; however, it is illustrative of the height partisanship had reached within two years of Gaines's arrival in the Territory.

In the fall of 1852 Governor Gaines received a letter from his son, Archibald, who at the time was visiting Detroit, Michigan. Archibald had visited Washington City a month or so previously and commenting on the activities of Congress he told his father, "I witnessed the last scenes of that august body, unparalleled in uproar and confusion."76 Speaking of the Governor's many friends in Washington, Kentucky, and elsewhere, Archibald said,

"I hope gen[eral] H[amilton] is with you and reliable: I need not say a word about Judge $\mathrm{N}$ [elson] whose patriotism, and integrity I found so fully tested in the dark hour of the gov[ernment] and always found battling [for] law and order against an overwhelming [odds] of unprincipled demagogues: I may say the same of Gen[eral] Preston-- I hope to see their names, together with those of the federal [officials] who sided with you, handed down in history as having guided you safely, through the darkest period, politically of the history of any of the states."77

Archibald continued his letter, mentioning that Ann Maria remained in Arkansas and wanted very much to be with her father in Oregon. He also wrote, "I am still determined to make Oregon my home, and will never leave it ..., and added a line about starting a cattle enterprise. Archibald then closed his letter telling his father that he hoped

76 Gaines Papers, reel 3, box 5, folder 2, frame 00111. Letter from Archibald K. Gaines to Governor John Gaines, dated Detroit, Michigan, September 14, 1852.

77 lbid. 
"that all things may progress smoothly and that peace and quiet may pervade the land, that your administration may be successful, and that Bush may not yet get the stroke of your raw hide." 78

That autumn the public and private turmoil Gaines had endured for over two years seemed to calm a bit -- except that is for the weather. Alonzo Skinner, who visited the Governor in mid November, complained to Gaines, in a letter written from Benton County, that the weather delayed his return trip to the Rogue Valley. "I have got this far on my way home," he said. "II] am laying by today for the purposes of [giving] it an opportunity to stop raining. I have a very fair prospect of rather a juicy time of it in going out to Rogue River."79

Weather aside, Governor Gaines had much to be thankful for in the autumn of 1852 . On Thursday morning, November 25,1852 , he married Miss Margaret Wands, the school teacher from Albany, New York, at the Oregon City residence of Surveyor General John B. Preston. The Reverend S. M. Fackler conducted the ceremony, after which the couple and their friends attended "an elegant function." Following their reception the happy couple rode in a small boat to Champoeg where they disembarked. They continued by horse and carriage to the Salem home of E. N. Cook. The wedding and carriage ride "was quite an event and luxury . . . as the carriage

\footnotetext{
78 Ibid.

79 lbid., folder 2, frame 00141 . Letter from Alonzo A. Skinner to Governor Gaines, dated November 14, 1852, Ineapolis[?], Benton County.
} 
was the only carriage of its kind in the Territory." 80 Gaines arranged for room and board in the home of the Reverend David Leslie, where he and Margaret lived until his term as governor expired.

The new Mrs. Gaines received kind words from Governor William Slade shortly after her wedding. After congratulating her on her marriage and sending his "kind and thoughtful regards" to her husband, Slade applauded her work as one of Oregon's pioneer teachers. He added, "I should have much preferred you continued as a teacher six months longer," but admits he shouldn't really complain since she reimbursed him for the expense in sending her to Oregon, and the money she sent provided the opportunity for another teacher to be sent to the Territory. ${ }^{81}$

In the early spring of 1853 the Governor received a letter from his youngest daughter, Tillie, who then lived in Nazareth, Kentucky. Apparently she had not yet heard of her father's marriage for she does not mention it. She relays a strong desire to see her father, however, and urges him to come back home to Kentucky:

"It has been a long time since you [wrote] and a long time since I wrote to you. ... Archibald and Abner visited ... on Christmas ... I begged them [not to] go back to Oregon. Pa [if] Pierce is elected I [know] that you will be turned out of office ... Pa pleas [sic] come back from Oregon . . Y Your affectionate child, Tillie Gaines." 82

80 Apley, Kay, "Two Oregon First Ladies For the Second Governor," Oregon Statesman, July 13, 1976, p. 7a.

81 Gaines Papers, reel 1, box 1, folder 2, frame 00067. Letter to Margaret Wands from William Slade, Middleburg, Vermont, unable to determine date.

82 Ibid., reel 3, box 5, folder three, frame 00166. Letter to John Pollard Gaines from his daughter Matilda Gaines, dated Nazareth, Kentucky, January 9, 1853. 
The Governor's son, Archibald, displayed shock at the news of his father's marriage. On March 23, 1853, he wrote in his journal,

". . . [M]y Father contrary to all expectation, married Miss Margaret B. Wands . . He has said nothing so far to any of his family on the subject which is somewhat strange. I understood thrc (sic) Dr. Sherman of the Geological Survey that in all probability it would take place, yet indulged the hope still, that it would not. It may all be for the best . . . and I have been thinking of taking again to Oregon. ..."83

Perhaps Archibald found it difficult to think of his father with a woman other than his mother but, for the Governor, after so many years of hardship the happiness he found with Margaret represented a new beginning -- and besides, he felt his new wife would be a good influence on his children. ${ }^{84}$ By mid-spring 1853, John Pollard Gaines's years as governor of the Oregon Territory had come to a close. When Governor Gaines first came to Oregon he advocated a clearer set of territorial laws; improved relations with the Indians; the permanent location of tive seat of Government; and creating, improving, and maintaining roads and waterways within the Territory for the growing number of settlers. The 1849 census of the Oregon Territory, taken during the administration of Governor Lane, showed a population of 9,083 . By 1850 -- just a year later -- the Territory's population had grown to over 13,000. Whether settlers returning from the California gold fields caused the rapid increase, as Charles Carey suggests, or just increased immigration, it

83 Archibald K. Gaines Journal, March 23, 1853.

84 Ibid., April 29, 1845. 
nonetheless shows the need Gaines saw for an improvement in the territorial road and navigation systems. ${ }^{85}$ In December of 1852 a new stage line began operation between Champoeg and Salem, and the following March a meeting was held to discuss the construction of a road between the Cascade Mountains and Fort Boise. ${ }^{86}$ The improvements for the southern portion of the Territory did not occur until after Gaines left office due to Indian wars and gold mining. John Preston, Surveyor General of the Territory, performed much of the survey work; however Jesse Applegate added survey information through his exploration of the Umpqua Valley. ${ }^{87}$ News of the railroad caused quite a stir in the Oregonian during the spring of 1853; however, it did not appear until long after Gaines left the office of governor. ${ }^{88}$ Gaines did see an improvement in mail delivery during his tenure as governor, though, when steamship service began running between California and Oregon twice a month in February of 1853. Incredibly, while Governor, Gaines also influenced the Oregon Territorial Legislature to create Pacific County, north of the Columbia River, and the counties of Umpqua and Lane in the southern portion of the Territory. ${ }^{89}$

\footnotetext{
85 Carey, p.482.

86 Griffith, E. J., "Transportation Items from the Weekly Oregonian, 1852 - 1865." Number 1 in a mimeographed series of brief manuscripts, records and studies compiled by the Works Progress Administration County and Local Records Survey of Oregon. This document has no date of compilation; however, The University of California, Los Angeles, received a copy on October 30, 1938.

87 Carey, p. 668.

88 See the Weekly Oregonian, March 19, 1853, p. 2; March 26, 1853, p. 2; and April 9, 1853, p. 2 .

89 "Oregon's Third Governor," The Sunday Oregonian, July 5, 1925, sec. 3, p. 6.
} 
Governor John Pollard Gaines endured his entire term in office. He did not resign or fail to perform his duties. He persevered relentlessly. Gaines's governorship was not unlike the political comings and goings of today. The political abuse thrown at Governor Gaines by "home rule" citizens and the Clique would not have been much different if he had been a Democrat. The measures he advocated probably would have been well received had he been a governor chosen by the people of Oregon. Gaines's years as Governor of the Oregon Territory were marred by politicians and businessmen eager to make a name and a fortune for themselves at the expense of anyone or anything that contradicted them or got in their way. After the election of Franklin Pierce as President of the United States, Joseph Lane came back to Oregon to displace Gaines. Lane requested the Oregon Territorial Governorship from Pierce. Moreover, he asked that his friend, George Curry, be given the position of territorial secretary. This action may have been part of a grand design of Lane's to obtain a local Oregonian for governor of the territory. Of this episode, Lane says in his autobiography, "I took care to have Mr. Gaines removed as a kind of complement to me." When he arrived in Oregon, Lane said to Gaines, "For your benefit I had been removed; now for my benefit you shall be removed." 90

90 Joseph Lane, "Lane Autobiography," Bancroft Library, University of California at Berkeley, 1878, p. 58. 
Once he displaced Gaines, Lane resigned after serving as governor for only three days. He never intended to serve the people locally as their governor, but rather sought a self-aggrandizement by serving the people of Oregon in far-off Washington. Suffice it to say his action was nothing short of vindictive. George Curry acted as governor for several months after Lane's resignation. When Democratic appointee John W. Davis ${ }^{91}$ arrived as Oregon's Territorial Governor the local Democrats immediately took a dislike to him. He was not a local, and therefore was not favored by the Clique. Lane admits that he and the Clique tried to get Davis to leave the territory by making his time as governor as miserable as possible. "We did not let him stay any longer than we could help; but we had to bear with him ... We did not remove Davis but persuaded him to leave; and after a year or two he

91 McMullin, Thomas A. and David Walker. Biographical Directory of American Territorial Governors, Westport, Connecticut: Meckler Publishing, 1984, pp. 278 -279. Born on April 16, 1799, in New Holland, Pennsylvania, John Wesly Davis, age ten, moved with his family to a farm near Shippensburg. Pennsylvania. He attended the Latin school there and later apprenticed to a clockmaker. In October 1820 he married Ann Hoover, who issued at least two children. In April of 1821, Davis graduated from the Baltimore Medical College and then practiced medicine first at Shippensburg and then from August 1821 to the spring of 1823 he practiced at Oldtown, Maryland. Davis moved to Carlisle, Indiana, and in 1828 ran for a position in the state senate. He lost the election, but received an appointment as Sergeant-atArms of the senate instead. A year later he became a judge of the probate court at Sullivan County, Indiana, and beginning in 1831 he began six terms in the Indiana House of Representatives, becoming Speaker of the House in 1833. With his growing popularity, Davis served two terms in the United States House of Representatives (1834 and 1838), returning to the Indiana House of Representatives in 1840, and again to Congress in 1843. Davis became speaker of the House of Representatives in 1845 . He served as commissioner to China from 1848 to 1851 , returning during the latter year as the speaker of the house of the Indiana Legislature. In 1852 Davis served as president of the Democratic National Convention which nominated Franklin Pierce candidate for the office of president of the United States. Pierce, in turn, appointed Davis as governor of the Oregon Territory. After a distressing eight months as Oregon's Territorial Governor, a thoroughly disgusted Davis resigned, left the territory, and returned to Indiana, where he once again became a member 
resigned. . . .92 Before departing the Territory Davis wrote an open letter to the Democrats of Oregon stating in essence that if they had voted for a constitutional convention in June of 1854 they would have embarked on the path toward statehood enabling themselves to elect their own governor. Nonetheless, in a roundabout way, the citizens of Oregon received their wish for a locally produced governor. George Curry, a local citizen and member of Oregon's Democratic Clique, again became Oregon's acting governor upon Davis's resignation. President Pierce appointed Curry to the position officially in November of 1854 and he served as Oregon's last Territorial Governor until March 3, 1859, when the Territory received notification of its statehood.

of the Indiana House of Representatives in 1856. Davis died on August 22, 1859, at Carlisle, Indiana.

92 "Lane Autobiography," p. 59. 
Chapter Nine

\section{THE POST-GOVERNOR YEARS}

"His official career as Gov (sic) of Oregon had ended by the appointment of Genl (sic) Lane in his stead ... his means in a pecuniary point had been reduced since his appointment to that office, his family greatly reduced by death and their remains scattered in different portions of the Earth, and tho (sic) he stood firm and bold, conscious of the rectitude of his intentions, and that all was intended, for the best as it unquestionably was, still there was an air of melancholy depicted in his countenance. Yet at the same time a firm and bold resolution not to falter in the discharge of every duty incumbent on him, to prosecute whatever he might undertake to the fulest (sic) extent look for'd (sic) to the future with hopes of success: This was his character through life--."1

The Democratic press in Oregon continued to attack Gaines after he left the office of governor. Interestingly though, when Alonzo Skinner decided to run as Oregon's delegate to Congress against Joseph Lane, the attacks suddenly shifted full force onto him. In the May 28, 1853, edition of the Oregon Statesman there appeared a ditty about Skinner composed after Lane and Skinner spoke at a public meeting in Albany.

$$
\begin{aligned}
& \text { "Heigh ho, poor 'Lonzo A., } \\
& \text { O! "Clever" 'Lonzo A., } \\
& \text { You'll get Skinned clean to the toes, } \\
& \text { On next election day." }
\end{aligned}
$$

Skinner lost his bid for Oregon's delegateship; however, he later served as a Circuit Judge for the Second Judicial District from 1866 - 1870, and afterward became Collector of Customs at Coos Bay. In May of 1856 he married Eliza Lincoln, one of the five school teachers sent to Oregon by Governor Slade in

\footnotetext{
Archibald K. Gaines Joumal, February 17, 1858, Oak Hills, Oregon Territory.

2 Statesman, May 28, 1853, p.2.
} 
1851. Most likely, Skinner met his wife through his friendship with Gaines and his wife Margaret.

Watching his friend campaigning for public office, Gaines could not resist finding a campaign of his own. In June of 1853 we find him participating in a Marion County election running for the position of the constable in Salem.

Nothing about the election appears in the papers -- only the election returns, which show Gaines received only sixteen of ninety-nine votes. ${ }^{3}$ A short article appeared in the Statesman some four months after the election, however, as a commentary on a bit of news appearing in the lowa State Gazette:

"Ex-Governor Gaines, was recently a candidate for constable in that Territory, and strange to say, was defeated -- lowa State Gazette."

"Not at all "strange" Mr. Gazette, but the most natural result in the world. His exexcellency of Encarnacion memory, is too well appreciated in Oregon, to be elected to the responsible post of constable. Four of Taylor's and Fillmore's appointees tried their speed in the late election--Gaines for constable, Coe for justice of the peace, and Holbrook and Hamilton for prosecuting attorneys--and all were distanced, and Gaines and Holbrook beaten out of sight. "In their death they were not divided." Par nobile fratrum."

After this loss Gaines decided to focus on improving the land claim he had acquired earlier in the year for himself and Mrs. Gaines. ${ }^{5}$ Locating a claim

\footnotetext{
3 Oregon Statesman, June 21, 1853, p. 2.

${ }^{4}$ Ibid., November 1, 1853, p. 2.

${ }^{5}$ It is not clear whether Gaines acquired a claim under the Donation Land Act or under a bounty warrant land grant. In a letter from Joseph Lane, dated Washington City, June 28, 1852, (see Gaines Papers, reel 3, box 5, folder 1, frame 00071) Gaines leams of his bounty warrant: "Herewith I have the honor to forward, your bounty warrant for 160 acres of land, you will however be surprised to learn that ... the Committee on Public Lands in the House has decided against the location of bounty warrants in Oregon until the lands are surveyed and brought into market. I do not intend however to give it up without another trial, and hope yet to get the privilege granted to all who are entitled to land for services rendered and at this [time] residents of Oregon." In January 1853 Gaines received a letter from James P. Miller (see Gaines Papers, reel 3, box 5, folder 3 ,
} 
approximately eight miles south of the Territorial Capital of Salem, Gaines built,

near a large fir tree, a colonial style structure "complete with columns and the conveniences of the era." ${ }^{\prime 6}$ Gaines planted some slippery elm trees from seed he brought with him around Cape Horn from Mount Vernon. The seeds from the slippery elm were sometimes used to treat physical ailments, such as rheumatism. $^{7}$

After settling his wife in her new home, Gaines sought to buy some cattle. He showed a particular interest in the Durham (also known as shorthorn) cattle found in the Mississippi and Ohio valleys. Charles Carey records a story about Durham cattle that involves Gaines's favorite judge, Orville Pratt:

"A faction of the Democrat party in the territorial period were known as 'Durhamites,' from a circumstance arising from a cattle deal. The story then current was that Judge $\mathrm{O}$. C. Pratt, who figured prominently in the politics of the day, had sold a band of Spanish cattle which he had bought from a man named Durham, the purchaser being led to believe that he was buying blooded Durham stock. Pratt's followers were consequently call "Durhamites" by their detractors."

frame 00168) regarding ". . good land and [plenty] of firewood \& water . . . it is divided. . . into two parts by oak. .." This letter also mentions a Mr. Robertson who has cattle and acreage for sale, and another piece of land, consisting of 80 fenced acres for sale. Moreover, the letter mentions that it is a "favorable time to purchase a farm," and discusses property on Lake Creek. Gaines may have used his bounty warrant to purchase land for his cattle or possibly investment property. I believe the land he built his farm on, near Salem, was a donation land claim because of the swom statement given by Thomson Ward, a neighbor, after his death (See Gaines Papers, reel 4, box 7 , folder 8 , frame 00297). "Personally appeared Thomson Ward [of Marion] County and made affidavit [that John Pollard] Gaines claimant to a Donation [land claim] of Marion died [at his] residence on the 9th of Dec 1857. Subscribed and swom to before me this 27th of Apl 1858 at Oregon City, \{signed\} James Guthrie Jr., receiver \{signed\} Thomson Ward. Land office [Marion County] The above affidavit of Thomson Ward copy on file in this office. \{Signed\} B. Jennings [?]" ${ }^{6}$ R. J. Hendricks, "Bits For Breakfast," August 29, 1929, p. 4; Beckham, "Jestens' English-Style Cottage Is Open To Visitors Sunday."

7 Beckham.

${ }^{8}$ Carey, pp. 690-691. 
Gaines left Oregon to pursue and purchase his cattle in the latter part of 1853, arriving at New Orleans during the second week of February 1854 where he met his son, Archibald. Writing in his journal, Archibald recalls seeing his father as he left his Uncle Legrand's office:

"I met him on the stairway as I was going . . into the street. He was coming up -I was not surprised at seeing him, as he was somewhat expected -- I need hardly say that he had the same firm step and manly form, as always, notwithstanding the great hardships and excitement through which he had passed since I had seen him, being two years wanting one month. He seem (sic) to be effected (sic) when he met me. I could not restrain my feelings--"'9

Gaines visited many "warm and devoted friends" while in New Orleans, including his daughter, Anne Maria. ${ }^{10}$ He persuaded his son to accompany him in locating the pure bred Durham cattle and drive them to his land claim in the Oregon Territory. Archibald then departed for Arkansas where he purchased 200 head of cattle. Gaines left New Orleans for Kentucky where he visited with family members and many friends. First, he visited the community of Nazareth from which place he picked up his youngest daughter, Tilly. From that point he proceeded to Bardstown, picking up his daughter Mary. Gaines, accompanied by his two daughters, then headed to Boone County to visit his brother Archibald. Placing his daughters in his brother's care, Gaines set out to find some cattle. After selecting thirty-five head of "fine Durham cattle ... from the meadows of Kentucky," Gaines departed his home state for Washington City where he settled

\footnotetext{
9 Archibald K. Gaines Joumal, February 17, 1858, Oak Hills, Oregon Territory.
}

10 lbid. 
his accounts (as governor of the Oregon Territory) with the federal government. ${ }^{11}$ Concluding his business in Washington, after also visiting with many friends, including Judge Underwood, Gaines departed for Kentucky once more to pick up his Durham cattle and then, saying good-bye once more to family and friends, he departed Kentucky for the last time.

Gaines's son Abner, in the meantime, had caught up with Archibald in Arkansas. The two brothers rendezvoused with their father and his thirty-five Durhams at Van Buren, Arkansas on April 27, 1854. The three men drove the cattle to Telequa "in the Cherokee Nation," at which place Gaines departed from his sons for New Orleans and then to the Oregon Territory by way of the Isthmus of Panama. Arriving home two months later he discovered his wife, Margaret, about five months pregnant with her first child. Remaining at home for two months working on the farm, Gaines waited for his sons to arrive with the cattle. Not hearing anything from them since his departure from Telequa he became concerned and decided to go search for them before his wife gave birth. He figured they would be close to the Boise River by that time and headed for that point.

Arriving at the small settlement of Boise in the middle August Gaines soon ascertained that his sons had not yet arrived. At that juncture he determined to head back home and wait for his sons there, remaining close to Margaret who

${ }^{11}$ Ibid. 
would be giving birth at any time. Then the news of a bloody massacre of the men, women, and children of a wagon train by the Snake Indians reached him and he became alarmed for his sons. The Oregon Statesman later published a letter about the incident from R. R. Thompson, Indian Agent, Middle Oregon Territory,

". . . detailing the intelligence of a most brutal outrage committed by the Winnesta band of Snake Indians, upon a company of immigrants known as Ward's train, from Mo. [sic] It was stated that there was eight men killed, four women and several children taken prisoners. On the morning of the 27th [August], I dispatched an express to [T]he Dalles, with a request to the commanding officer of that post to send what assistance he could . . I now concluded to hasten as fast as possible, with a hope that I would be able to reclaim the prisoners, or, at least, make the attempt, before the Indians could be apprised of the approach of our forces. I was accompanied by ex-governor J. P. Gaines, who had just returned from Boise, where he had been to meet his sons, who were coming across the plains with cattle; not hearing of them; he had retraced his steps for home. When on Willow [C]reek he heard of the massacre, also of my having passed; he thereupon concluded to overtake me and return with a view to ascertain the fate of his sons. On the 1st of September we arrived at the Grand Ronde, where we first ascertained that neither age nor sex had been spared by those inhuman monsters, but that all had shared a common fate. . ." "12

Gaines became extremely concerned for his sons' welfare after he witnessed the scene of the massacre. In desperation he wrote a quick note to his son Archibald and dispatched it with a Mr. McArthur from Fort Hall. The note read,

"Dear Archibald, We start out this morning in [another attempt to locate the] Indians . . . after a search of a few days I sh[ared my concern about you] with Wm. Thompson ... [l] hope to overtake you [at] Umatilla-- The mountain [range] is [dangerous and] weather is unpromising ... If you cross the mountains, take the [lower] road to the Deschutes-- The roads separate on [a] hill beyond John Days [sic] River-- The Bull is [the] most essential animal in your train, and [I urge

12 Oregon Statesman, October 24, 1854, p. 2. 
you] to do everything in your power for his comfort . . . give him salt and cut grass for him ... Be patient-- Your Affectionate Father Jno. P. Gaines ${ }^{\prime 13}$

A number of days later Gaines arrived back in Boise at nightfall. Ironically, his sons arrived in the area the next morning. Hearing of their arrival Gaines immediately departed for their location. Archibald recalls the moment he saw his father:

"He came out a few miles the morning we arrived in full gallop, I can hardly state my surprise at meeting him in that far off Indian Country, but duty which ever impelled him urged him to this step. He returned with us, and reached Salem on the 27 th Oct (sic) 1854, leaving our cattle the first winter at Walla [Walla] and a most tedious journey we had--.."14

Archibald returned to Walla Walla the following May accompanied by Samuel

Frazier whom he had met while crossing the plains. By June 1, 1855, they had returned with the cattle to the Gaines farm in Salem.

During Gaines's absence from home, Margaret gave birth to a daughter on September 11, 1854. They named her Katherine Floretta Gaines, but called her Katie. For the next few months Gaines busied himself on the farm and began breeding his cattle. He did business with a number of local farmers seeking to introduce a good hardy strain of cattle into their herds. On April 8, 1856, he contracted with William Pickens of Linn County:

"I William Pickens of Lynn (sic) County Oregon, have this day received of John P. Gaines forty five head of cattle, besides nine sucking calves, which I agree to take to my farm in said county and graze and take care of the same as his the said Gaines's property and return them to him together with three fourths of the

${ }^{13}$ Gaines Papers, reel 2, box 4, folder 1, frames 00454-00455. Letter from John P. Gaines to his son Archibald K. Gaines, dated Boise River, September [1854].

${ }^{14}$ Archibald K. Gaines Joumal, February 17, 1858, Oak Hills, Oregon Territory. 
increase I retaining the one fourth of the increase as a remuneration for my trouble. I am to have the privilege of milking any or all of the cows as I may choose during the time I keep them. I am to salt them well, the said Gaines paying one half the cost thereof- This contract to last two years, or longer as may then be agreed upon- In the lot there are eight steers and the remainder females -- We are both to assist in returning the cattle at the termination of the contract." ${ }^{\prime 15}$

On April 18, 1855, Gaines received the Whig nomination as Oregon's delegate to Congress. This meant running against Joseph Lane for the position and Gaines decided to make a strong attempt. Recalling the campaign, Gaines's son Archibald wrote, "The canvass was a most exciting one, and my Father completely triumphed over his competitor (sic) on the stump..." The next several months were very exciting indeed!

The Democrats held their convention on April 11, 1855. O. C. Pratt, a contender in the bid for nomination, lost his bid to Joseph Lane. Out of fifty-nine votes Pratt received only six. As mentioned above, the Whigs met and nominated Gaines as their candidate on April 18. The following day the American Party held their convention and also nominated Gaines. Both candidates received nicknames from the local newspapers and each other's parties. Gaines became "the Hero of Encarnacion" referring to his unfortunate experience in the Mexican War, and Lane became "the Mary-Ann of the Mexican War," for lack of anything better to call him. ${ }^{16}$ The campaign began quietly enough in the southern portion of the Territory. Members of the Clique became

\footnotetext{
${ }^{15}$ Gaines Papers, reel 4, box 7, folder 8, frame 00299. Contract between John P. Gaines and William Pickens, dated Oak Hills, Oregon April 8, 18[56].

${ }^{16}$ Clark, p. 275.
} 
concerned that Lane was being too soft on Gaines. They accused Gaines of "abusing Lane from the stump."17 On May 5, 1855, G. H. Ambrose wrote a letter to Asahel Bush describing the situation:

"I think it would be well if Delazon Smith or some other good stump speaker would visit this section of the country. I have no doubt of the result being favourable (sic), but it behooves us as democrats to leave nothing undone, the mass of people in this county know but little of Gov. Gains (sic), many have never heard of him before... Whig stock has risen 100 per cent in the market since Gaines's appearance --he has made a rather favourable impression upon his Whig brethren, his mode of speaking is to assail Genl. Lane and all other prominent Democrats in the Territory, which keeps Lane diverted . . ."18

On May 7, 1855, Mathew Deady wrote to Bush with a similar account of the happenings on the campaign trail:

"All these men (Whigs) here who talked so much about abolitionism and Henry are now rampant for Gaines who occupies in his public speeches the position of hostility to the Nebraska Act, and the right of the people to regulate their own domestic policy. By way of justification for his contradiction they say that Gaines has given them private pledges on the subject. . . Lane has never answered any of the attacks upon Democrats, nor those upon himself . . . You had perhaps take them up in the Statesman, or get somebody else to take the stump. G[aines] has bullied and abused L[ane] from the start, L[ane] has taken it all so far as meekly and mildly as ever Skinner did his abuse in '53. No one is doing anything in this county except Ambrose that I know of. For Gods sake do something in the Willamette Valley or we are beaten. ..."19

Lane, probably sensing his peer's apprehensions, devised a course to bring

Gaines's political career to an end. Writing to Bush on May 7, 1855, Lane said,

"I have met the old coon to day (sic) and skinned him to the heels, this days (sic) will tell. Now about business . . . remember Encarnacion, surrender without a fight. Taylor said he would have fought a little, his holding on to the peoples (sic)

\footnotetext{
17 Ibid.

18 "Political Correspondence," letter to Asahel Bush from G. H. Ambrose, dated Dardanelles, Oregon Territory, May 5, 1855.

19 Ibid., Letter to Asahel Bush from Mathew Deady, dated Jacksonville, May 7, 1855.
} 
money against the will of the people or acts of the Legislative Assembly -- give him fits -- talk about all his maladministration acts . . . and say what you please about my successes in Mexico. . . . Jo will bring the papers up to this place, and Barnes will take them to Ambrose and he will go to Althouse, Waldo, and other mining towns where they will tell. . . We must succeed; I shall get a handsome majority of Jackson \& Douglas, -- I shall do my duty to the last fight gallantly \& leave nothing undone ..."20

Bush did as Lane requested. He rehashed the location issue, the Rogue River peace treaty, and dug up all the dirt he could on Gaines's military career. In the

May 19,1855 , edition of the Statesman Bush wrote,

'The fruits of Gaines' (sic) intermeddling, while Gov. of Oregon, it seems will never have an end. His obstruction of the erection of a penitentiary and our public buildings, and the consequent impunity which crime has here for want of a prison in which to secure the criminal, all are familiar with. . .."21

In the same issue appeared an article that commented on Gaines's parole of honor during the Mexican War:

". . . With Cassius M. Clay, and others, he was permitted to go at large in the Mexican country upon his parole of honor, or upon his word of honor that he would not run away from the Mexican authorities. He did run away, and made his escape to the American lines." ${ }^{22}$

Reading the last comment, Gaines drifted back to the days of his capture and imprisonment in Mexico. The account given in the Statesman represented the Mexican version of the story. Gaines, as one of the men in command of the captured detachments, remembered clearly what happened. Both he and Major Solon Borland ${ }^{23}$ of the Arkansas Cavalry had been sent on separate reconnoiter

\footnotetext{
${ }^{20}$ Ibid., Letter to Asahel Bush from Joseph Lane, dated Winchester, May 7, 1855.

21 Statesman, May 19, 1855, p. 2.

22 Ibid.

${ }^{23}$ Peskin, Allan, (ed.), Volunteers: The Mexican War Joumals of Private Richard Coulter and Sergeant Thomas Barclay, Company E, Second Pennsylvania Infantry, Kent, Ohio: The Kent
} 
missions to ascertain the strength of the Mexicans in the area. On January 19, 1847, Gaines, a captain, a lieutenant, and thirty men departed their camp and "explored the country in every direction, by day and by night." ${ }^{24}$ Gaines remembered sleeping with his clothes on, "generally booted and spurred."25 In all they traveled about eighty miles. On a particular stormy night they chanced on a hacienda known as Encarnacion and there they met Borland and his men. The commanders posted sentries to keep a look out and nothing seemed amiss in the night; however, at dawn on January 23,1847 , they found themselves surrounded by a large number of Mexican soldiers. The Mexicans surrounded them in every direction. A white flag approached the hacienda Encarnicion from one side and the troops drew nearer on the other sides. Gaines recalled,

"We required their troops to retire previous to any conference, which being complied with, the flag approached, and the result was that in one hour we would answer their admonition of surrender . . . They said they had 3,000 men present, and the demonstrations around us left but little room to doubt its truth substantially. The result of our deliberation was that we would hear a proposition from them in answer to which they proposed sending an officer of equal rank with myself while I repaired to their camp. ..." ${ }^{26}$

After a Mexican soldier of equal rank came to the hacienda, Major Gaines went out to assess the situation. General Miñon promised Gaines that if the

State University Press, 1991, p. 225fn Bom in 1808, Solon Borland of Arkansas, served as a major in the Mexican War. After gaining his freedom from the Mexicans, Bortand retumed to the United States where he became a senator from the state of Arkansas. He served as a United States diplomat in Central America then in 1861, upon returning home to Arkansas, he joined the Confederate Army. He attained the rank of brigadier general before his retirement.

${ }^{24}$ Licking Valley Register, March 27, 1847, p. 3. Letter from Major John P. Gaines, dated San Luis Potosi, Mexico, February 10, 1847.

25 Ibid.

${ }^{26}$ Ibid. 
American soldiers surrendered they would "be treated and respected as prisoners of war."27 Gaines remembered the agonizing decision of surrender:

"We had sixty-six men and six officers, with about twenty rounds of ammunition each--no water, no bread, no meat . . "28 A majority of the officers voted to surrender, which was not an easy decision according to Gaines:

"Notwithstanding the great disparity of numbers--about forty-four to one--our men exhibited a thirst for the fight truly astonishing. If there was a single individual who left the slightest disinclination to the conflict it could not be detected, and many, very many actually shed tears at the necessity of surrender. To have allowed them to fight under the circumstance would have subjected them to inevitable destruction, without rendering any valuable service to their country." ${ }^{29}$

The following day the men traveled by foot, the officers on their horses, to San Luis Potosi. That evening one of Borland's officers, Captain Daniel Drake Henrie, escaped for fear of his life. The following day a Mexican guide, who had helped the troops in their reconnoiter, received the death penalty, being shot in front of the men by a firing squad. This alarmed Gaines, for Miñon had assured him, as an officer and a gentleman, that they would all be treated fairly. The Mexicans showed the worse possible cruelty that day:

"A pistol was twice presented to my breast by Col. [sic] Sambonero, the officer having us in charge, and a sword drawn on me by Lieut. [sic] Crozet. An order was given to fire on Capt. [sic] C. M. Clay, and the whole force under his command which happened not to be executed at the instant . . . Capt. [sic] Clay explaining that none but Henrie desired to escape ..."

\footnotetext{
${ }^{27}$ Ibid., March 13, 1847, p. 2. Letter from John J. Hardin, Colonel of the First Regiment, Illinois Volunteers.

${ }_{28}$ Ibid., March 27, 1847, p. 3. Letter from Major John P. Gaines, dated San Luis Potosi, Mexico, February 10, 1847.

${ }^{29}$ Ibid.

30 Ibid., June 25, 1847, p. 2. Letter from Major John P. Gaines to Major General Winfield Scott, dated City of Mexico, May 3, 1847.
} 
They remained at San Luis Potosi until February 15, 1847, when the Mexicans marched them to Mexico City at which place they arrived on February 27 . The Mexicans placed their prisoners in the Castle of Santiago. Gaines recalled, "We reached the castle after midnight, and were smuggled into it with great privacy. A few moments after we entered an alarm was raised by the discharge of four guns in rapid succession. We heard some one (sic) say four men were killed and ten had escaped. We now ascertained that we were lodged in a prison containing two hundred convicted felons. The escape made it necessary to change their cells, and they were brought out and passed through the yard where we were chained two and two, and placed in safer dungeons." ${ }^{31}$

The safety consisted of confinement in "a cold dungeon upon a brick floor, without even a blanket, a chair or a table."32 There they remained until well into April at which juncture the Mexicans gave the commanding officers a parole of honor; in other words, they allowed the A.nerican commanders to roam freely around the city during the day, but at night they again became confined. After several more months of this treatment and promises of a prisoner exchange between the Mexicans and the Americans, Gaines and the other officers became frustrated.

The men had been prisoners since the end of January and it was now August. Gaines recalled the day he withdrew his parole of honor. Summoning the American officers to the headquarters of General Lombardini, the Mexicans

${ }^{31}$ Ibid., May 28, 1847, p. 3. Letter from Major John P. Gaines to his brother Archibald, dated Castle of Santiago, City of Mexico, April 3, 1847. The Licking Valley Register printed excerpts of this letter, stating that much of it contained private matters of no concem to the public.

32 Ibid., July 2, 1847, p. 2. "A letter from Major Gaines to his family bearing date, Mexico, May 25th." 
had informed them of their intention to move the prisoners further into the heart of their country to a place called Toluca. Through their interpreter, Colonel Almante, Gaines told the Mexicans,

". . . that the Mexican government had violated the provisions of the exchange with General Taylor, by keeping us as prisoners from the 24th of February until the 1st of August, 1847, whilst Gen. [sic] Taylor had released his prisoners, and complied faithfully with every part of his agreement with the Mexican government-at the same time stating, that he wished them distinctly to understand, that his parole was at end-that he withdrew it unconditionally. . .,"33

Major Borland and Captain C. C. Danley also withdrew their paroles. Gaines took the added precaution of bringing with him an interpreter, "Mr. Heavens, an English gentleman of respectability, who [understood] the Spanish language, and spoke it well," making certain the Mexicans knew he had withdrawn his parole. ${ }^{34}$ The order to move to Toluca came the following morning. Gaines immediately went to the home of Mr. Smith, an American acquaintance he had met in the city. While dining there a Mexican colonel appeared at the door with two letters: one from Mr. Smith for his wife, advising her to leave the city and one for Gaines from General Worth. The colonel, Gaines discovered, was

". . . a daring, bold, and courageous highwayman by profession, and quite wealthy, which gave him considerable consideration and influence . . . After delivering his letters, he remarked that 'he had been told by Mr. Smith that he had

${ }^{33}$ Gaines Papers, reel 3, box 5, folder 1 frame 00055. Letter to John Pollard Gaines from Captain C. C. Danley, dated Little Rock, Arkansas, June 26, 1852. Danley included a newspaper clipping from the June 2, 1848, Arkansas Democrat, from which I have taken this quotation. Danley's letter is fifteen pages long including the newspaper clipping. The letter mentions reading an article about Gaines' conduct in the Mexican War in a copy of the Oregon Statesman, dated March 2, 1852. 34 Ibid. 
friends in Mexico who might desire to come to Pueblo; if so, he could conduct them.' I immediately seized the opportunity and entered into a treaty with him." ${ }^{\text {,35 }}$

Gaines escaped Mexico City on August 2, 1847. On August 5, at around ten at night, he passed safely through Mexican lines and into American territory. He gave General Scott intelligence regarding Santa Anna, the number of his troops, and the location of their main defense lines. Gaines joined Scott as a volunteer aid-de-camp and with Scott's a-my "gallantly fought . . . throught the fields and forts of Contreras, San Antoniao, Churubusco, Molino del Rey, Chapultepec, and the gates of San Cosme and Tacubay or Belén, into the captial of Mexico." ${ }^{36}$ He continued with Scott through the end of his year's enlistment. It had been a difficult year, and now Bush and company forced him to relive it.

Gaines continued to campaign hard and his supporters really thought they had a chance to beat Lane; however, the polls told a different story. Gaines and his party underestimated the power of the Democratic party in the Oregon Territory. Even though he pulled a majority of votes out of three counties, and in several others the race was very close, Lane defeated him by a vote of 6,178 to 3,943. Gaines faced his defeat boldly and with honor just as Wilson had in 1851 and Skinner in 1853.

\footnotetext{
${ }^{35}$ Gaines, Major John P, Circular Letter from Major John P. Gaines, of Kentucky, to His Constituents of the Tenth Congressional District, Washington, D. C.: Towers, undated.

${ }^{36}$ Scott, Memoirs of Lieut. General Scott, LLD., p. 536.
} 
Election Returns for the Office of Delegate to Congress

During the Election Years 1851, 1853, and 1855

\begin{tabular}{|c|c|c|c|}
\hline \multicolumn{4}{|c|}{$1851^{37}$} \\
\hline County & Lane (D) & Wilson $(\mathrm{W})$ & Total Votes \\
\hline Clackamas & 359 & 30 & 389 \\
Marion & 324 & 172 & 496 \\
Yamhill & 271 & 27 & 298 \\
Benton & 113 & 28 & 141 \\
Umpqua & 119 & 0 & 119 \\
Polk & 248 & 28 & 276 \\
Washington & 412 & 103 & 515 \\
Lane & 43 & 5 & 48 \\
Pacific & 21 & 0 & 21 \\
Clark & 83 & 1 & 84 \\
Lewis & 118 & 32 & 150 \\
Linn & 95 & 109 & 204 \\
Clatsop & 169 & 8 & 177 \\
Total Votes & 2375 & 543 & 2918 \\
\hline
\end{tabular}

\begin{tabular}{|c|c|c|c|}
\hline \multicolumn{5}{|c|}{$1853^{38}$} \\
\hline County & Lane $(\mathrm{D})$ & Skinner $(\mathrm{W})$ & Total Votes \\
\hline Jackson & 659 & 553 & 1212 \\
Marion & 709 & 301 & 1010 \\
Linn & 479 & 251 & 730 \\
Lane & 276 & 113 & 389 \\
Clackamas & 570 & 328 & 898 \\
Benton & 215 & 108 & 323 \\
Polk & 319 & 134 & 453 \\
Yamhill & 304 & 312 & 616 \\
Douglas & 223 & 83 & 306 \\
Washington & 557 & 569 & 1126 \\
Umpqua & 102 & 121 & 223 \\
Clatsop & 116 & 86 & 202 \\
Total Votes & 4529 & 2959 & 7488 \\
\hline
\end{tabular}

${ }^{37}$ Oregon Statesman, July 4, 1851, p. 2. The counties of Pacific, Clark, and Lewis, while part of the Oregon Terntory in 1851, became part of the Washington Territory in 1853. Lane won by an eighty-two percent majority.

38 Ibid., June 30,1853, p. 2. The Whigs made a promising gain during this election. Winning in two counties, Skinner received almost forty percent of the votes but Lane won with a clear sixty percent majority. 


\begin{tabular}{|c|c|c|c|}
\hline \multicolumn{3}{|c|}{$1855^{39}$} \\
\hline County & Lane (D) & Gaines $(\mathrm{W})$ & Total Votes \\
\hline Jackson & 819 & 677 & 1496 \\
Marion & 742 & 471 & 1213 \\
Linn & 783 & 399 & 1182 \\
Lane & 561 & 327 & 888 \\
Clackamas & 410 & 272 & 682 \\
Benton & 376 & 193 & 569 \\
Polk & 501 & 160 & 661 \\
Yamhill & 371 & 333 & 704 \\
Douglas & 453 & 196 & 649 \\
Multnomah & 340 & 267 & 607 \\
Washington & 262 & 286 & 548 \\
Umpqua & 193 & 127 & 320 \\
Coos & 139 & 104 & 243 \\
Wasco & 70 & 5 & 75 \\
Clatsop & 94 & 41 & 135 \\
Tillamook & 2 & 18 & 20 \\
Columbia & 62 & 67 & 129 \\
Total Votes & 6178 & 3943 & 10,121 \\
\hline
\end{tabular}

After the election Gaines returned to his farm in Marion County. He worked hard and little by little he made improvements to the structure and surrounding lands during 1856 and 1857 . His cattle enterprise, while not as successful as he would have liked, brought him satisfaction. In May of 1857 he received word about the death of his beloved daughter, Tillie, at Somerville, Tennessee, where she had been attending school. Making matters worse, she died on the anniversary of Florelle's burial on the Island of Santa Catharina in 1850. When Archibald returned to the farm that day, he found his father, ". . laboring so much under the effects of this news that he seemed to have lost his cheerfulness. His misfortunes seemed necessarily to have separated him

\footnotetext{
39 Ibid., August 18, 1855, p. 2. Multnomah, Coos, Wasco, Tillamook, and Columbia counties were organized after 1853. Gaines did about as well as Skinner did in the election of 1853 . He gamered nearly thirty-nine percent of the votes but Lane won handily with a sixty-one percent majonty.
} 
from a portion of his family, which, taken in connection with Matilda's death, for the first time in his life had an injurious effect on his health and constitution-- ${ }^{340}$

Nonetheless, Gaines persevered and continued to improve his home. During the summer of 1857 he "greatly improved his dwelling, and for the first time made it entirely comfortable."41 During the fall the family enjoyed the fruits of their labor, and then, on November 30,1857 , at nine in the evening just as everyone had retired for the night, Gaines "was taken with a congestive chill, and a most sever (sic) attack of congestion of the lungs. ${ }^{, 42}$ Margaret called to Archibald to bring the vinegar cruet and she bathed her husband's forehead with the liquid, which seemed to relieve him somewhat. He survived the night and the next day felt a little better. He continued in this manner until December 3, when Margaret decided to send Archibald for Doctor Belt in Salem. The doctor could not come out that day so Archibald described the symptoms as best he could. The doctor gave Archibald an emetic for his father, but Archibald protested, telling the doctor, "that if he saw his father he might think differently in regard to the medicine."43 The doctor still insisted that Archibald take the medicine to his father and after promising to come out to the farm early the next morning Archibald left, taking the medicine with him.

\footnotetext{
${ }_{40}^{40}$ Archibald K. Gaines Journal, February 17, 1858, Oak Hills, Oregon Territory.

${ }^{41}$ Ibid.

42 lbid.

${ }^{43}$ Ibid.
} 
Sitting up in bed when Archibald entered the room Gaines told his son he thought he felt a little better and declined the medicine. Archibald recalled, "... He was much interested in the news from the States, especially in regard to the pecuniary panic then existing-- $\mathrm{He}$ asked me to read him the news, at the same time was exceedingly restless: I continued to read to him for about three quarters of an hour: He finally remarked in regard to the panic, that it would be a great blessing to some of the poor operatives now in the states thrown out of employment, if they could only be in Oregon, that they could get employment: it was the last remark he ever made of a political nature. . . ."44

After a while Archibald persuaded his father to take the emetic the doctor had given him. About half an hour later he became very ill, throwing up and having a terrible time of it. He continued in this manner for two more long hours. After drinking some tea he rested. The next morning the doctor arrived, examined Gaines, and left enough medicine for a day and a half. Instead of getting better Gaines grew worse. Archibald sent for his brother, Abner, on Saturday, December 5, and Abner went to bring back the doctor. The doctor finally appeared the next day at noon and gave Gaines another prescription, but it failed to produce better results. On Monday Doctor Belt sent his partner Dr. Uncles who changed Gaines's treatment and remained with him until Tuesday,

December 8. Gaines still showed no signs of improvement. On December 9 , 1857, Doctor Belt visited Gaines a last time. At about 6:15 that evening, John Pollard Gaines's, "spirit took its flight calmly and with but little struggle, from Earth." $^{45}$

44 Ibid.
${ }^{45}$ Ibid. 
Retaining his mental faculties, Gaines spoke distinctly up to within fifteen

minutes of his death. Archibald spent the last moments of his father's life beside

him:

"He would occasionally, press my hand warmly and affectionately showing clearly that he was aware of his situation, and thereby carrying out the character of his whole life, action instead of words-- for all trying occasions thro (sic) life, his looks and actions always had more effect upon those with whom he was thrown in contact, than his words-- I regret that I should have been the only one of his children that could be present at his last moment ... I imprinted a kiss on my Father's cheek, before his death, held his arm, and smoothed his hair, during the last 4 hours of his time never leaving him, and closed his eyes in death.

${ }^{46}$ Ibid., Typhod fever caused Gaines's death. 


\section{Chapter Ten}

\section{EPILOGUE}

"He was . . up to the highest point in r.is duty, around his own fire side, in the halls of legislation, or defending his country on the field of battle-- He is now at peace, his work on Earth has been finished, and has indeed had but little spare time--he has indeed but few or no idle days to account for--He had all the requisites, necessary, for a seat at the right hand of him who rules and conducts all things-"-"1

An Episcopal minister preached a funeral for John Pollard Gaines at his home on Thursday, December 10,1857, at noon. That afternoon at two o'clock the minister assisted in placing Gaines's remains "amidst a respectable concourse of people" at the cemetery one and a half miles south of Salem. ${ }^{2}$ On December 20, Archibald departed Salem for the Clatsop Plains arriving there on Christmas day. On December 26, accompanied by some of his friends, Archibald went to his mother's grave and disinterred her remains. He returned to Salem New Years Eve and on January 8, 1858, Archibald placed his mother's remains next to his Father "in a beautiful spot in the cemetery at Salem." ${ }^{3}$ Today one can view their graves at the Odd Fellows or Pioneer Cemetery, located on South Commercial in Salem. If one walks about halfway up the hill on the South Commercial side of the cemetery a tall shaft will come into view. Below it is a

\footnotetext{
1 Archibald K. Gaines Joumal, February 17, 1858, Oak Hills, Oregon Territory.

${ }^{2}$ Ibid.

${ }^{3}$ Ibid.
} 
marble slab under which rest Gaines and his first wife. On the shaft one can read,

"Let me go, for the day breaketh. John Pollard Gaines; born in Virginia, September 22, 1795; served in the War of 1812; major of Kentucky Cavalry in the Mexican War, 1846; member of Congress from Kentucky 1847 and 1849; governor of Oregon from November, 1849 until May, 1853. Died December 9, 1857, aged 62 years. An ardent patriot, a kind and indulgent husband and father. In every relation and station in life an honest man."

Ironically, Asahel Bush and John Pollard Gaines, political enemies in life, rest in plots next to each other and Samuel Thurston rests close by.

Archibald, Anna Maria, Mary Elizabeth, Richard, Katie, and Margaret carried on with their lives after the death of their father and husband. Anna Maria and Mary Elizabeth settled with relatives near Little Rock, Arkansas. There they remained with their brother, Richard, and John's brothers (referred to as Uncle LeGrand, Uncle Davies, and Uncle Ben by Anna Maria in letters written to her brother, Abner). ${ }^{4}$

Abner attended school at Danville, Kentucky until 1853 when, as mentioned above, he returned to Oregon with his father and brother and the herd of Durham cattle. Although a farmer by occupation, Abner also served as a United States Assessor in Oregon from 1861 to 1862 . He married Mary Ellen

\footnotetext{
${ }^{4}$ See Anna Maria Gaines to brother Abner P. Gaines, Homestead, June 27, 1858, August 26 , 1858, July 2, 1859, October 24, 1859, October 8, 1860, May 3, 1864, Oregon Historical Society, Mss 683-F32.
} 
Moody a few months before John's death, and they had several children including Archie Anna, Ida, John, Richard, Hattie, and Wilbur. ${ }^{5}$

Archibald remained in Oregon until March 10,1852, when he left to "try my fortune in other parts." His journey differed slightly in that he traveled across the Isthmus of Panama instead of completely around Cape Horn. Reaching New York on April 15, 1852, he remained in the East for a year before he thought about returning to Oregon. In 1853 , when his father came to New Orleans, Archibald agreed to help him drive his Durham cattle back to Oregon. He remained in Oregon assisting his stepmother with the farm near Salem and settling his father's estate until 1864 when he returned to Little Rock, Arkansas, settling near his sisters and brother, Richard. He passed away in 1895.

John's second wife, Margaret, and his three-year-old daughter, Katie, stayed in Oregon for several years after his death. They left Salem for New York during 1864 late in the Civil War. Katie married Homer Green, a poet and writer of fiction, on June 30, 1886, at Albany, New York. She died at Honesdale, Pennsylvania on January $1,1943 .^{6}$

A gentlemen purporting to have known John Pollard Gaines intimately remembered him in a newspaper article written in 1885 .

\footnotetext{
${ }^{5}$ Lang, p. 715. Of these children I have been able to locate one offspring who lives in Tillamook. Her name is Margaret Reed and descends from Wilbur Gaines.

6 "Daughter of 3d Oregon Territory Governor Dead," Oregon Journal, January 14, 1943, section 1, p. 8.
} 
"I have a pleasant memory of Governor Gaines, who was a fine type of Kentuckian, and came to Oregon to remove his family from the evils of slavery. I was well acquainted with him and visited occasionally his beautiful home in the hills, about seven miles south of Salem, where he tried about the very first experiment of introducing short horns, or Durhams as then called, into this region. It is unpleasant to know that his enterprise was ahead of the times and so premature that he was a heavy loser. His life in Oregon was a disappointment, for he failed to realize results from his cattle importation, and as his means were limited it seriously crippled his finances. But the Gaines herd is today the foundation stock of many good living herds, and the enterprise of Governor Gaines was of great benefit to Oregon cattle interests. Our stock men will recognize that fact and unite with me in rendering due justice to an early enterprise that rewarded the public rather than its public-spirited projector."

While his political experience in the Oregon Territory was often negative,

he did experience some humorous moments. One such time occurred during his campaign against Joseph Lane for the delegateship in Congress. Again, an old friend of Gaines recalls the occasion:

"I remember when once here in Salem they had an intellectual encounter when we thought Gaines was decidedly the best man. He capped his argument with a story of an old farmer who watched a hen trying to sit on too many eggs, "Old speck! You'll have to spread yourself," said the farmer. The application was made when summing up the multitudinous promises Lane had made in the opening speech, and the homely wit and humor of it took the crowd, so that the Lane adherents and the old general himself had to join in the laugh at his expense. Governor Gaines was a good debater and made some very remarkable canvasses when the fact of democratic supremacy being so absolute is taken into account." ${ }^{.8}$

John Pollard Gaines was in the minority on the issue of slavery. He was ahead of his time in this regard. Some individuals have speculated what it would have been like if Abraham Lincoln had become Oregon's second territorial

\footnotetext{
7 "Pioneer Days."

${ }^{8} \mathrm{lbid}$
} 
governor. It is interesting to think that Gaines may have laid a foundation for Lincoln in Congress when he first presented the bill to abolish the slave trade in Washington City. And what if Lincoln had come to Oregon? Would Gaines have continued his work against slavery? Would he have joined the Republican party? Could he have attained the Presidency of the United States? It is possible that these questions may never be answered but it is interesting to ponder them.

John Pollard Gaines spent the last seven years of his life in Oregon. They were years filled with personal grief and political strife. As someone who knew the man personally said,

"Gaines was a man only to be known and appreciated by those who knew him well enough to understand him well. Owing to newspaper prejudice, those opposed to him no doubt believed him cowardly, dishonest, dishonorable and bad, whereas he was brave, honorable, chivalrous and far above average men in true principle and moral and religious sentiment. Even at this late day, I take pleasure in doing honor to the memory of a true man, who left slavery behind him and sought a home for his children beyond its reach." ${ }^{\prime 9}$

${ }^{9}$ Ibid. 
Bibliography

\section{Unpublished Manuscripts and Letters}

Bush, Asahel. "Political Correspondence, Asahel Bush II." Portland State University Library, Portland, Oregon, undated.

Cummins, Leslie, of the Kentucky Legislative Research Commission. Letter to Katherine Huit, August 11, 1995.

Gaines, Archibald Kinkead. Archibald K. Gaines Journal, November 1849 February 1858. WA-MS-208, Microfilm version from the Coe Collection, Yale University Library, New Haven, Connecticut.

Gaines Family Papers. MSS 683, Oregon Historical Society Library.

Gaines, John Pollard. "Around Cape Horn: A Voyage from New York to Oregon Territory by Sailing in 1850." Forth Worth, Texas, Public Library.

Gaines, John Pollard. "March of the First Regiment of Kentucky Volunteer Cavalry, From Memphis-Tennessee to Mexico, During the War with Mexico in 1846." Fort Worth, Texas, Public Library.

Gaines, John Pollard. John Pollard Gaines Papers. Albany, New York: New York State Library.

Gaines, Major John P. Circular Letter from Major John P. Gaines, of Kentucky, to His Constituents of the Tenth Congressional District. Washington, D. C.: Towers, undated.

Gaines, Pendleton. Letter to Katherine Huit. May 28, 1994.

Lane, Harriet. "General Joseph Lane and His Relation to the History of Oregon Between the Years 1849 and 1853." Bachelor's Thesis, University of Oregon, 1909.

Lane, Joseph. Lane Autobiography, Bancroft Library, 1878.

McCauley, Charles S. "Letterbook of Official Letters Sent, 1850." Naval War College, Naval History Collection, Newport, Rhode Island. 
Newton, Lena, "The Public Career of Joseph Lane." Thesis, University of Oregon, 1912.

Valentine, Elvin L. "The American Territorial Governor." Unpublished thesis for the degree of Doctor of Philosophy, Graduate School, University of Wisconsin, July $2,1928$.

Contemporary Books, Newspapers, Memoirs, and Government Documents

----. "Asahel Bush," The Morning Oregorian (December 24, 1913), p. 8.

--.-. "Asahel Bush As A Boss," The Sunday Oregonian (February 1, 1914), section three, p. 6.

----.. "Asahel Bush Dies; Funeral Is Today," The Morning Oregonian (December 23, 1913), p. 3.

Barlow, Samuel. "Petition to the Provisional Government of the Territory of Oregon for a Charter to Build a Wagon Road." Papers of the Provisional and Territorial Governments of Oregon. Microfilm document 1416, Portland: Oregon Historical Society Library, 1846.

Barlow, William. "Reminiscences of Seventy Years," Oregon Historical Quarterly, XIII (October 1912), 240-286.

The Congressional Globe: Sketches of the Debates and Proceedings of the Second Session of the Thirtieth Congress. City of Washington: Blair \& Reeves, 1849.

Covington [Kentucky] Journal, August 11, 1848 - January 30, 1858.

----. "Daughter of 3d Oregon Territory Governor Dead," Oregon Journal (January 14, 1943), section one, p. 8.

Griffith, E. J. "Transportation Items from the Weekly Oregonian, 1852 - 1865." Undated.

[Covington, Kentucky] Licking Valley Register, April 16, 1842 - October 29, 1847.

General Laws, Salem, Oregon: Asahel Bush, Territorial Printer, 1854. 
Mansfield, Edward D. The Mexican War: A History of Its Origin and A Detailed Account of the Victories Which Terminated in the Surrender of the Capital; With the Official Dispatches of the Generals, New York: A. S. Barnes \& Co., 1850.

---. "Men Await Ghouls At Tomb of Bush," The Morning Oregonian (December 27, 1913), p. 1.

Odell, Mrs. W. H. "Hon. Samuel R. Thurston," Oregon Pioneer Association Transactions of 1894, V (1895), 70-73.

Oregon Statesman, 1851-1861; 1929-1934.

Perkins, George Gilpin. A Kentucky Judge. Washington, D. C.: [no publisher listed], 1931.

Peskin, Allan, ed. Volunteers: The Mexican War Journals of Private Richard Coulter and Sergeant Thomas Barclay, Company E, Second Pennsylvania Infantry. Kent, Ohio: The Kent State University Press, 1991.

----. "Pioneer Days: Reminiscences of One of Oregon's Territorial Governors, John P. Gaines," The Morning Oregonian, (July 26, 1885) p. 3.

----. Report of the Adjutant General of the State of Kentucky Mexican War Volunteers, Frankfort, Kentucky: John D. Woods, State Printer, 1889.

Scott, John A. Encarnation: or, the Prisoners in Mexico: Being an Account of Their Capture, Treatment, and Travels. Louisville, Kentucky: G. H. Monsarrat \& Co's Steam Press, 1848.

Scott, Winfield. Memoirs of Lieut. General Scott, LLD. New York: Sheldon \& Company, 1864.

Thurston, Samuel Royal. "Diary of Samuel Royal Thurston, November 21, 1849 August 28, 1850," Oregon Historical Quarterly, XV (September 1914), 152 - 205.

Weekly Oregonian, The, 1850-1859.

Western, Biography of Joseph Lane, Washington: Congressional Globe, 1852.

Western Globe, 1840. 


\section{Secondary Sources}

-.-. "150th Anniversary of the City of Walton, 1840-1990." Walton, Kentucky, January 21, 1990.

Apley, Kay. "Two Oregon First Ladies For the Second Governor." Oregon Statesman, July 13, 1976, p. 7a.

Bancroft, Hubert Howe. History of Oregon 1848-1888. Volume II. San Francisco: The History Company Publishers, 1888.

Barlow, Mary S. "History of the Barlow Road," Oregon Historical Quarterly, III (January 1902), 71-81.

Barlow, Mary S. "Reminiscences of Oregon Pioneers," Transactions of the Twenty Third Annual Reunion of the Oregon Pioneer Association, VI (1895), 6986.

Beckham, Cathy. "Jestens' English-Style Cottage Is Open to Visitors Sunday." The Oregon Statesman Capital Journal (September 30, 1978), section B, p. 1.

Biographical Encyclopaedia of Kentucky of the Dead and Living Men of the Nineteenth Century, The. Cincinnati: J. M. Armstrong \& Company, 1878.

Bloom, John Porter. The Amenican Terntorial System. Athens, Ohio: Ohio University Press, 1973.

Branigar, Thomas. "The Murder of Cyrenius Hooker." Oregon Historical Quarterly, LXXV (December 1974), pp. 344-359.

Brown, Thomas. Politics and Statesmanship: Essays on the American Whig Party. New York: Columbia University Press, 1985.

Carey, Charles H. A General History of Oregon. Portland, Oregon: Metropolitan Press, 1936.

Carey, Charles H. "The Creation of Oregon as a State," Oregon Historical Quarterly, XXVI (December 1925), pp. 281-308.

Carroll, Malcolm E. Origins of the Whig Party. Durham: Duke University Press, 1925. 
Case, Victoria, The Quiet Life of Mrs. General Lane. Garden City, New York: Doubleday \& Company, Inc., 1952.

Clark, Malcolm Jr. Eden Seekers: The Settlement of Oregon, 1818-1862. Boston: Houghton Mifflin Company, 1981.

Collins, Lewis, History of Kentucky. Covington: Collins \& Co., 1882.

Corning, Howard McKinley, ed. Dictionary of Oregon History. Portland: Binfords \& Mort, Publishers, 1956.

Eblen, Jack Ericson. The First and Second United States Empires: Governors and Territorial Government, 1784-1912. Pittsburgh: University of Pittsburgh Press, 1968.

Formisano, Ronald P. The Birth of Mass Political Parties: Michigan, 1827-1861. Princeton: Princeton University Press, 1971.

Gaston, Joseph. The Centennial History of Oregon. Chicago: The S. J. Clarke Publishing Company, 1912.

Gatell, Frank Otto. "Money and Party in Jacksonian America: A Quantitative Look at New York City's Men of Quality," Political Science Quarterly, LXXXII (1967), 235-252.

Genovese, Eugene. Roll, Jordan, Roll: The World the Slaveholders Made. New York: Pantheon Books, 1972.

Genovese, Eugene. The World the Slaveholders Made. New York: Vintage Books, 1969.

Haskell, Thomas. "Capitalism and the Origins of Human Sensibility, American Historical Review, 90 (April and June, 1985), 339-361, 547-566.

Hendricks, R. J., "Bits for Breakfast" column, Oregon Statesman (August 29, 1929), p. 4; (August 30, 1929), p. 4; (February 12, 1930), p. 4; (March 20, 1941), p. 4; (March 21, 1941), p. 4; (March 22, 1941), p. 4.

Hendrickson, James E., Joe Lane of Oregon: Machine Politics and the Sectional Crisis, 1849-1861. New Haven: Yale University Press, 1967.

Himes, George H. "History of the Press of Oregon, 1839 - 1850," The Oregon Historical Quarterly, V (1904), pp. 327-370. 
Hinckley, T. C., ed. Studies in Territorial History. Manhattan, Kansas: Sunflower University Press, 1981.

Holt, Michael Fitzgibbon. Political Parties and American Political Development: From the Age of Jackson to the Age of Lincoln. Baton Rouge: Louisiana State University Press, 1992.

Howe, Daniel Walker. "The Evangelical Movement and Political Culture in the North During the Second Party System," Journal of American History, 77 (March 1, 1991), 1216-1238.

Hussey, John A. Champoeg: Place of Transition. Portland: Oregon Historical Society Press, 1967.

Johannsen, Robert W. Frontier Politics and the Sectional Conflict: The Pacific Northwest on the Eve of the Civil War. Seattle: University of Washington Press, 1955.

Kelly, Sister Margaret Jean, The Career of Joseph Lane, Frontier Politician. Washington, D.C.: The Catholic University of America Press, 1942.

Kincaid, H. R. Biennial Report of the Secretary of State -- Oregon 1897-98, Salem, Oregon: W. H. Leeds, State Printer, 1899.

Lang, H. O., editor. History of the Willamette Valley. Portland: Geo. H. Himes, Book and Job Printer, 1885.

Lawson, Gary. "Territorial Governments and the Limits of Formalism," California Law Review, 74 ( July 1990), 853-911.

Lockley, Fred. History of the Columbia River Valley: From The Dalles to the Sea. Vol. I, Chicago: The S. J. Clarke Publishing Company, 1928.

Ludington, Flora Belle. "Oregon Newspapers 1846-1870," Oregon Historical Quarterly, XXVI (September 1925), 256-258.

Marshall, Lynn L. "The Strange Stillbirth of the Whig Party," American Historical Review, LXXII (January 1967), 445-468.

McCormick, Richard L. "The Party Period and Public Policy," Journal of American History, LXVI (1979), 279-298. 
McMullin, Thomas A. and David Walker. Biographical Directory of American Territorial Governors. Westport, Connecticut: Meckler Publishing, 1984.

Menefee, Leah Collins and Lowell Tiller. "Cutoff Fever," Oregon Historical Quarterly, 77 (December 1976), 309-340.

Merk, Frederick. The Oregon Question. Cambridge: The Belknap Press of Harvard University Press, 1967.

Morgan, Dale. ed., Overland in 1846. Volume II, Georgetown, California: Talisman Press, 1963.

Morrison, Michael A. "New Territory Versus No Territory: The Whig Party and the Politics of Western Expansion, 1846-1849," The Western Historical Quarterly, 23 (February 1, 1992), 25-51.

Morrison, Michael A. "Westward the Curse of Empire: Texas Annexation and the American Whig Party," Journal of the Early Republic, 10 (Summer 1990), 221249.

Peyton, J. Lewis. History of Augusta County, Virginia. Staunton, Virginia: Samuel M. Yost \& Son, 1882.

Remini, Robert V. Henry Clay: Statesman for the Union, New York: W. W. Norton \& Company, 1991.

Rennick, Robert M. Kentucky Place Names. Lexington, Kentucky: The University of Kentucky Press, 1987.

Rich, Robert. "A Wilderness of Whigs," Journal of Social History, IV (1971), 263276.

Sutton, Bob, "Asahel Bush, The Oregon Statesman," The Oregonian (March 7 , 1971), Northwest section, 10-11.

Turnbull, George S. Governors of Oregon. Portland: Binfords and Mort Publishers, 1959.

Turnbull, George S. History of Oregon Newspapers. Portland: Binfords and Mort Publishers, 1939.

Wilkins, Mary Barlow. "Samuel Kimbrough Barlow: A Pioneer Road Builder of Oregon," Oregon Historical Quarterly, XXVI (1925), 210-224. 